\title{
8. SITES 629 AND 630: LITTLE BAHAMA BANK ${ }^{1}$
}

\author{
Shipboard Scientific Party ${ }^{2}$
}

\section{HOLE 629A}

Date occupied: 19 February 1985, 2030 EST

Date departed: 20 February 1985, 0600 EST

Time on hole: $9.5 \mathrm{hr}$

Position: $27^{\circ} 24.39^{\prime} \mathrm{N}, 78^{\circ} 22.10^{\prime} \mathrm{W}$

Water depth (sea level; corrected m, echo-sounding): 553

Water depth (rig floor; corrected m, echo-sounding): 563

Bottom felt (m, drill pipe): 563

Total depth (m): 579.5

Penetration (m): 16.5

Number of cores: 3

Total length of cored section (m): 16.5

Total core recovered $(\mathrm{m}): 6.2$

Core recovery $(\%): 37.6$

Oldest sediment cored:

Depth sub-bottom (m): 16.5

Nature: sandy carbonate ooze, lime sand, and rubble

Age: late Pleistocene (NN21)

Measured velocity $(\mathrm{km} / \mathrm{s})$ : approximately 1.5

${ }^{1}$ Austin, J. A., Jr., Schlager, W., Palmer, A. A., et al., 1986. Proc., Init. Repts. (Pt. A), ODP, 101,

2 James A. Austin Jr. (Co-Chief Scientist), Institute for Geophysics, University of Texas at Austin, Austin, TX 78751; Wolfgang Schlager (Co-Chief Scientist), Rosenstiel School of Marine and Atmospheric Sciences, Miami, FL 33149 (current address: Vrije Universiteit, Instituut v. Aardwetenschappen, Postbus 7161, 1007 MC Amsterdam, Netherlands); Amanda A. Palmer, Staff Scientist, Ocean Drilling Program, Texas A\&M University, College Station, TX 77843; Paul A. Comet, The University, Newcastle-Upon-Tyne, Newcastle, United Kingdom (current address: Core Labs Singapore, 24A-Lim Teck Boo Rd., Singapore 1953); André Droxler, Rosenstiel School of Marine and Atmospheric Sciences, Miami, FL 33149 (current address: Department of Geology, University of South Carolina, Columbia, SC 29208); Gregor Eberli, Geologisches Institut, ETH-Zentrum, Zürich, Switzerland (current address: Fisher Island Station, University of Miami, Miami, FL 33139); Eric Fourcade, Laboratoire de Stratigraphie, Université Pierre et Marie Curie, 4 Place Jussieu 75230, Paris Cedex 05, France; Raymond Freeman-Lynde, Department of Geology, University of Georgia, Athens, GA 30602; Craig S. Fulthorpe, Department of Geological Sciences, Northwestern University, Evanston, IL 60201; Gill Harwood, Department of Geology, The University, Newcastle-Upon-Tyne, NE1 7RU United Kingdom; Gerhard Kuhn, Geologisches Institut Göttingen, Federal Republic of Germany (current address: Alfred Wegener Institut für Polarforschung, Columbus Center, D-2850 Bremerhaven, West Germany); Dawn Lavoie, NORDA Code 363, Seafloor Geosciences Division, NSTL, MS 39529; Mark Leckie, Woods Hole Oceanographic Institution, Woods Hole, MA 02543 (current address: Department of Geology and Geography, University of Massachusetts, Amherst, MA 01003); Allan J. Melillo, Department of Geological Sciences, Rutgers University, New Brunswick, NJ 08903 (current address: Chevron U.S.A., New Orleans, LA 70114); Arthur Moore, Marathon Oil Company, P.O. Box 269, Littleton, CO 80160; Henry T. Mullins, Department of Geology, Syracuse University, Syracuse, NY 13210; Christian Ravenne, Institut Français du Pétrole, B.P. 311, 92506 Rueil Malmaison Cedex, France; William W. Sager, Department of Oceanography, Texas A\&M University, College Station, TX 77843; Peter Swart, Fisher Island Station, University of Miami, Miami, FL 33139 (current address: Marine Geology and Geophysics, Rosenstiel School of Marine and Atmospheric Sciences, Miami, FL 33149); Joost W. Verbeek, Dutch Geological Survey, P.O. Box 157, 2000 A.D. Haarlem, Netherlands; David K. Watkins, Department of Geology, University of Nebraska, Lincoln, NE 68588; Colin Williams, Borehole Research Group, Lamont-Doherty Geological Observatory, Palisades, NY 10964.

\section{HOLE 630A}

Date occupied: 20 February 1985, 1020 EST

Date departed: 21 February 1985, 1020 EST

Time on hole: 1 day

Position: $27^{\circ} 26.94^{\prime} \mathrm{N}, 78^{\circ} 20.43^{\prime} \mathrm{W}$

Water depth (sea level; corrected m, echo-sounding): 807

Water depth (rig floor; corrected m, echo-sounding): 817

Bottom felt (m, drill pipe): 815

Total depth (m): 1065.3

Penetration (m): 250.3

Number of cores: 26

Total length of cored section (m): 250.3

Total core recovered $(\mathrm{m}): 220.3$

Core recovery $(\%): 88$

Oldest sediment cored:

Depth sub-bottom (m): 250.3

Nature: periplatform ooze and chalk with turbidites

Age: late Miocene (N16/17)

Measured velocity $(\mathrm{km} / \mathrm{s}): 1.75$, multichannel seismic-reflection profile LBB-18; 1.7, Hamilton Frame on individual samples; 1.8, split cores in liner

\section{HOLE 630B}

Date occupied: 21 February 1985, 1020 EST

Date departed: 21 February 1985, 1900 EST

Time on hole: $8.67 \mathrm{hr}$

Position: $27^{\circ} 26.94^{\prime} \mathrm{N}, 78^{\circ} 20.43^{\prime} \mathrm{W}$

Water depth (sea level; corrected m, echo-sounding): 807

Water depth (rig floor; corrected m, echo-sounding): 817

Bottom felt (m, drill pipe): 815

Total depth (m): 895.4

Penetration (m): 80.4

Number of cores: 9

Total length of cored section (m): 80.4

Total core recovered $(\mathrm{m}): 79.6$

Core recovery $(\%): 99$

Oldest sediment cored:

Depth sub-bottom (m): 80.4

Nature: periplatform carbonate ooze

Age: latest Miocene-early Pliocene, NN12/13, N18/19 (extrapolated from Hole 630A)

Measured velocity $(\mathrm{km} / \mathrm{s}): 1.75$, multichannel seismic-reflection profile LBB-18; 1.7, Hamilton Frame on individual samples and on split cores in liner 


\section{HOLE 630C}

Date occupied: 21 February 1985, 1900 EST

Date departed: 21 February 1985, 2300 EST

Time on hole: $4 \mathrm{hr}$

Position: $27^{\circ} 26.94^{\prime} \mathrm{N}, 78^{\circ} 20.43^{\prime} \mathrm{W}$

Water depth (sea level; corrected m, echo-sounding): 807

Water depth (rig floor; corrected m, echo-sounding): 817

Bottom felt (m, drill pipe): 815

Total depth (m): 824.3

Penetration (m): 9.3

Number of cores: 1

Total length of cored section $(\mathrm{m}): 9.3$

Total core recovered $(\mathrm{m}): 9.3$

Core recovery (\%): 100

Oldest sediment cored:

Depth sub-bottom (m): 9.3

Nature: periplatform ooze with bank-derived aragonite

Age: Pleistocene

Measured velocity $(\mathrm{km} / \mathrm{s}): 1.65$, multichannel seismic-reflection profile; 1.7, Hamilton Frame on individual samples and on split cores in liner

Principal results: Site 629 on the upper part of the northern slope of Little Bahama Bank was occupied from 19 to 20 February 1985. Hole $629 \mathrm{~A}$, drilled at $27^{\circ} 24.39^{\prime} \mathrm{N}, 78^{\circ} 22.10^{\prime} \mathrm{W}$, in $553 \mathrm{~m}$ water depth, represents an attempt to spud in at a modified BAH-7A. Approximately $16.5 \mathrm{~m}$ of sediment was penetrated with the hydraulic-pistoncore/extended-core-barrel (HPC/XCB) technique before hard layers halted further drilling. The material recovered consists of sandy carbonate ooze, lime sand and rubble, and fragments of friable limestone, all of late Quaternary age.

Site 630 was occupied on 20 and 21 February 1985 . Three holes were drilled, all of which are located at $27^{\circ} 26.94^{\prime} \mathrm{N}, 78^{\circ} 20.43^{\prime} \mathrm{W}$, in $807 \mathrm{~m}$ water depth. Hole $630 \mathrm{~A}$ penetrated $250 \mathrm{~m}$ of sediment with $\mathrm{HPC} / \mathrm{XCB}$ techniques, recovery being $88 \%$. Hole $630 \mathrm{~B}$ duplicated the top $80.4 \mathrm{~m}$, using the HPC system; recovery was $99 \%$. Hole $630 \mathrm{C}$ took a third core of the mud line $(9.3 \mathrm{~m}, 100 \%$ recovery).

Site 630 represents the upper end of the slope transect off Little Bahama Bank. It is at the crest of an interfluve where mud accumulates, yet sand and rubble from the platform bypass this zone in turbidity currents that are confined to adjacent gullies.

The stratigraphic section at Site 630 consists of the following: (1) 0-146 m sub-bottom; periplatform carbonate ooze (with abundant bank-derived aragonite), late Miocene to Holocene; and (2) 146-250 m sub-bottom; periplatform ooze and chalk with turbidites, late Miocene.

The record suggests that bypassing of sandy turbidity currents persisted for the last 6 m.y., and ooze accumulated at a rate of 27-62 $\mathrm{m} / \mathrm{m}$.y. Before $6 \mathrm{Ma}$, the site formed part of the turbidite apron at the foot of the gullied slope. Site 630 provides an excellent record of the export of fine sediment by the carbonate platform during the last 10 m.y.

To facilitate high-resolution stratigraphy at this location, drilling at Hole 630B duplicated the Pliocene-Pleistocene section to just below the site of the 3.5-Ma event, the presumed onset of Northern Hemisphere glaciation.

\section{OPERATIONS SUMMARY}

The JOIDES Resolution left Site 628 for BAH-7-A, approximately $8 \mathrm{n}$. mi away, at $1630 \mathrm{hr}, 19$ February 1985 (Fig. 1, Site 627 chapter, this volume). The ship followed a course of $204^{\circ}$ along the trend of site-survey line LBB-18. The speed was less than $4 \mathrm{kt}$, as the ship's dynamic-positioning thrusters were extended. En route, the decision was made to drill in deeper water than the intersection of LBB-1 and LBB-18, so Site 629 was situated on LBB-03 between LBB-10 and LBB-18 (Fig. 1).

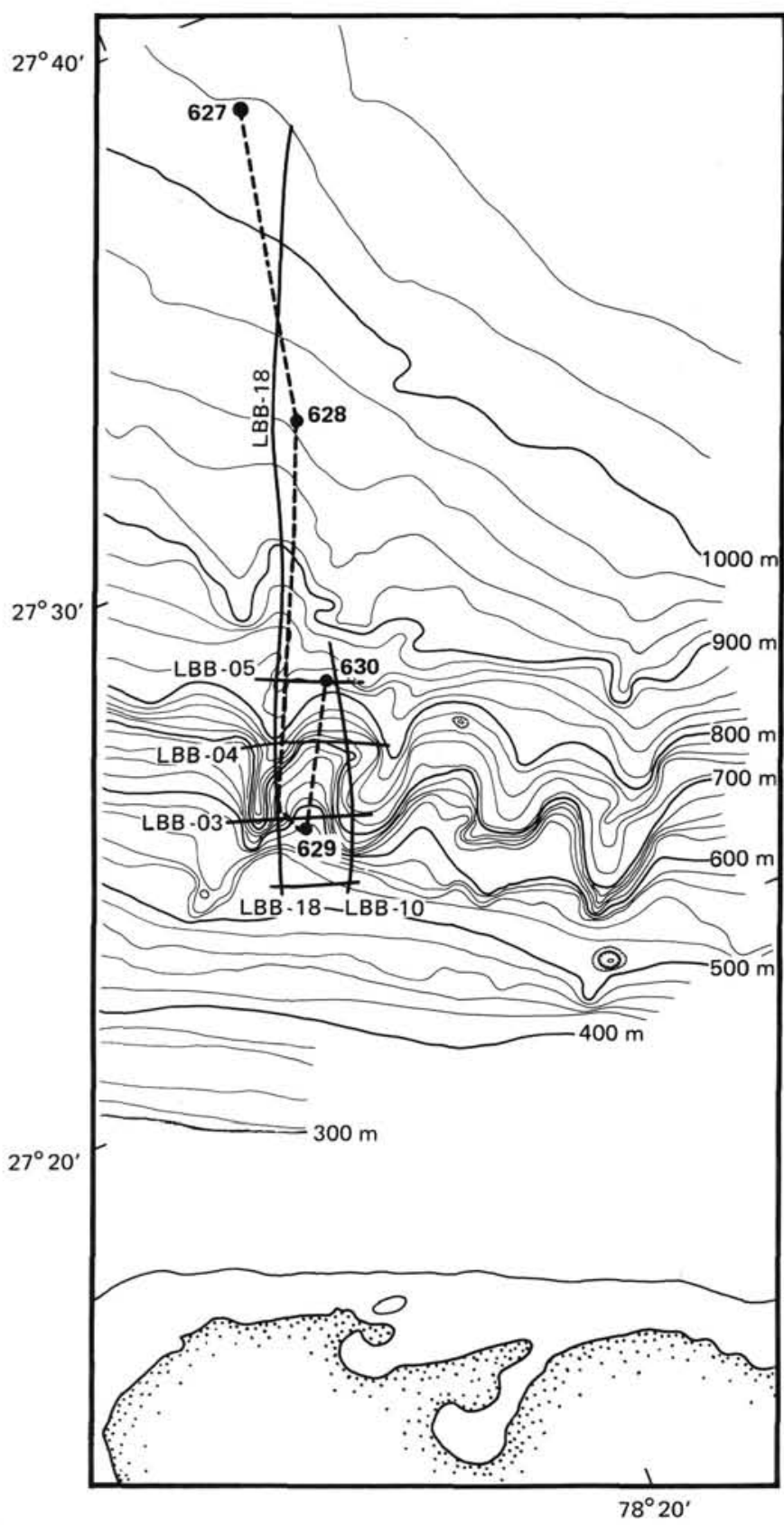

Figure 1. Leg 101 ship track (dashed line), upper slope, northern Little Bahama Bank.

At the crossing of LBB-18 and LBB-03, the ship changed course along LBB-03 until the $3.5 / 12-\mathrm{kHz}$ systems indicated that the ship was at the crest of an interfluve between gullies, suggested by the compiled bathymetry (Van Buren and Mullins, 1983, modified by the site-survey results; Fig. 1). At $2030 \mathrm{hr}$, a beacon was lowered on a taut wire, and dynamic positioning began. SATNAV readings, however, suggested that the ship was approximately $150 \mathrm{~m}$ west-southwest of the top of the interfluve, so the taut wire was retrieved, an additional positioning maneuver was performed, and the taut wire and beacon redeployed. Site 629 occupies a position of $27^{\circ} 24.335-437^{\prime} \mathrm{N}, 78^{\circ} 22.059-131^{\prime} \mathrm{W}$ (Fig. 1). Water depth at this location was $545 \mathrm{~m}$ (uncorr.), $553 \mathrm{~m}$ (corr.).

A first attempt at a mud-line HPC core was unsuccessful at $2300 \mathrm{hr}$ because of a crushed liner and an incomplete piston 
stroke, but a second attempt was successful just after $2400 \mathrm{hr}$, 19 February. The second HPC core also delivered an incomplete stroke, suggesting the presence of coarse-grained bottom sediments, so we decided to switch immediately to XCB techniques in an attempt to spud in. However, the XCB recovered only fragments of friable limestone along with lime sand and rubble, convincing everyone that further operations at this location were impossible.

Permission was received to move several nautical miles downslope along the same topographic high to the intersection of lines LBB-05 and LBB-10 (Fig. 1). The Resolution left Site 629 for Site 630 at $0600 \mathrm{hr}, 20$ February, at approximately $1 \mathrm{kt}$ with thrusters extended, leaving $350 \mathrm{~m}$ of drill pipe in the water. The taut wire and beacon were pulled only $20 \mathrm{~m}$ above the mud line. Radar bearings from islands on Little Bahama Bank were used along with LORAN C to keep the ship on course during this short transit. The taut wire was lowered again at $0800 \mathrm{hr}$, but a move approximately $0.3 \mathrm{n}$. mi to the northeast was necessary $1.5 \mathrm{hr}$ later. Dynamic positioning began at Site 630 at $1020 \mathrm{hr}, 20 \mathrm{Feb}-$ ruary. The final Site 630 position was as follows: $27^{\circ} 26.902-$ $977^{\prime} \mathrm{N}, 78^{\circ} 20.382-486^{\prime} \mathrm{W}$. Water depth was $797 \mathrm{~m}$ (uncorr.) and $807 \mathrm{~m}$ (corr.).

The mud-line HPC for Hole $630 \mathrm{~A}$ was recovered at $1320 \mathrm{hr}$ on 20 February. Over the next $11 \mathrm{hr}, 18 \mathrm{HPC}$ cores were recovered to a sub-bottom depth of $172.1 \mathrm{~m}$, recovery being $98.9 \%$. These HPC cores were followed by eight XCB cores to a total sub-bottom depth of $250.3 \mathrm{~m}$. Recovery with the XCB was $64.1 \%$, for a total recovery of $88 \%$ in Hole $630 \mathrm{~A}$. The decision had been made to double-HPC the upper part of the section at this site, and a mud-line core for Hole 630B was successful at $1150 \mathrm{hr}, 21$ February. Nine HPC cores were recovered in Hole 630B to a sub-bottom depth of $80.4 \mathrm{~m}$, recovery being $99 \%$, when operations ended. A third mud-line HPC, necessary at this site (Hole $630 \mathrm{C}$ ) for inorganic-geochemistry sampling of the surface interstitial waters, was recovered successfully at $1942 \mathrm{hr}$, recovery being $100 \%$. The JOIDES Resolution left Site 630 for BAH-11-A in southeastern Exuma Sound at 2300 hr, 21 February.

The coring summary for Sites 629 and 630 appears in Table 1.

\section{SEDIMENTOLOGY}

\section{Introduction}

Three holes were drilled at Site 630 . Hole $630 \mathrm{~A}$ penetrated $250.3 \mathrm{~m}$ below sea floor (bsf) and recovered $220 \mathrm{~m}$ of core $(88 \%)$. Hole 630B penetrated $80.4 \mathrm{mbsf}$, recovery being $79.6 \mathrm{~m}(98 \%)$. Hole $630 \mathrm{C}$ penetrated $9.3 \mathrm{~m}$ sub-bottom and recovered $9.3 \mathrm{~m}$ $(100 \%)$.

Hole $630 \mathrm{~A}$ consists predominantly of soft and stiff calcareous ooze and minor amounts of chalk and, rarely, limestone. Most smear slides of the ooze contain needles, which are confirmed by x-ray-diffraction (XRD) analysis ("Inorganic Geochemistry" section, this chapter) to be aragonite. This sediment is more properly classified as periplatform ooze. The calcite fraction consists of foraminifers and nannofossils in varying proportions. Layers of unlithified to partly lithified packstone are rarely observed in the upper half of the sequence, whereas in the lower part they are more common. The ooze is white, showing a few subtle color variations (10YR 8/1, 5Y 8/1, 5Y 8/2). Bioturbation appears as mottling of grayish, greenish, or light brownish colors, and pyritic areas as relatively darker areas of light gray $(10 \mathrm{YR} 8 / 2)$. The packstone layers typically have a more yellowish $(2.5 \mathrm{Y} 8 / 2)$ or grayish (10YR $7 / 1)$ tone than does the white ooze background. Because of the homogeneous aspect of the sedimentary sequence, Hole $630 \mathrm{~A}$ is subdivided into only two units. Unit I comprises the upper $146 \mathrm{~m}$ and consists of a pure calcareous ooze almost devoid of packstone layers; Unit II con- sists of the lower $105 \mathrm{~m}$, where packstone layers alternating with calcareous ooze are numerous (see Fig. 2).

\section{Unit I (0-146 m sub-bottom, Cores 630A-1H through 630A-16H-3)}

Unit I consists of at least $90 \%$ calcareous ooze at different stages of induration. On average, the top of Unit I ( $0-75 \mathrm{~m}$ subbottom) varies between soft and stiff ooze, whereas the bottom (75-146 m sub-bottom) is almost entirely soft ooze. Packstone layers are rare throughout Unit I, although they occur more commonly at the extreme top (Core 630A-1H) and between 68 and $85 \mathrm{~m}$ sub-bottom (Cores $630 \mathrm{~A}-8 \mathrm{H}$ and $630 \mathrm{~A}-9 \mathrm{H}$ ). The layers, typically a few $\mathrm{cm}$ to $10 \mathrm{~cm}$ thick, can be as thick as $50 \mathrm{~cm}$ in a few places. Maximum grain size at the base of layers is medium sand, consisting mainly of planktonic foraminifers. The thickest layers commonly display graded bedding. Accordingly, these packstone layers are interpreted as being turbidites.

Although the calcareous ooze is visually homogeneous throughout Unit I, smear slide estimates (generally three per core) of foraminifers, nannofossils, micrite, and aragonite needles exhibit trends that we used to divide Unit I into three subunits: a lower subunit, IC (90-146 m sub-bottom), a middle subunit, IB (28-90 m sub-bottom), and an upper subunit, IA (0-28 $\mathrm{m}$ sub-bottom) (see Fig. 2 and Table 2). Micrite in smear slide estimates includes both fine carbonate grains (a few to $25 \mu \mathrm{m}$ ) of uncertain origin and fine aragonite needles.

Subunit IC is enriched in foraminifers $(30 \%)$ and has an intermediate nannofossil content $(\mathbf{4 0 \%})$ and a micrite content $(15 \%)$ with rare aragonite needles. Subunit IB shows a low foraminiferal content $(10 \%)$, a high nannofossil content $(50 \%)$, and an intermediate micrite content $(25 \%)$ with common aragonite needles. Subunit IA displays a low content of both foraminifers $(7.5 \%)$ and nannofossils $(15 \%)$, whereas the micrite content is at its maximum $(45 \%)$ with abundant aragonite needles. The foraminifer content clearly decreases upward, whereas micrite clearly increases upward, as does the proportion of aragonite needles. The nannofossil content shows a minimum in Subunit IA, a maximum in Subunit IB, and an intermediate value in Subunit IC. The upward trend of increasing micrite and aragonite indicates a gradual increase through time of the input and preservation of bank-derived particles. This interpretation is strengthened by the carbonate mineralogy of Unit I. The lower part of Unit I shows no aragonite, the middle part some aragonite $(20 \%-25 \%)$, and the upper part the most aragonite $(40 \%$ $45 \%$ ) (see Fig. 3 and "Inorganic Geochemistry" section). The step boundaries of the aragonite content match those of the sedimentary sequence defined by smear slide estimates.

Several clay-rich layers are observed in Subunit IA, at $2.5 \mathrm{~m}$ sub-bottom and between 17 and $21 \mathrm{~m}$ sub-bottom (see Fig. 4). These layers correlate well in Holes 630A, 630B, and 630C. Similar layers have been observed at similar depths in Hole 628A and Holes 627A and 627B.

\section{Unit II (146-250 m sub-bottom; Cores 630A-16H-4 through 630A-26X)}

Unit II consists of chalk and ooze $(60 \%)$ interbedded with unlithified to partly lithified packstone layers $(40 \%)$. Packstone layers are thicker at the base (as thick as $100-120 \mathrm{~cm}$ ) than at the top (a few $\mathrm{cm}$ to $20 \mathrm{~cm}$ ) of Unit II, where they are more numerous (e.g., 37 layers in Core 630A-17H and 50 layers in Core $630 \mathrm{~A}-18 \mathrm{H})$. Grain size at the base of the layers ranges from fine to very coarse sand. Fine to medium sands are primarily foraminifers, and coarse sands are aggregates. Only one grainstone layer is reported (top of Core 630A-22X). Sharp bases and graded bedding are common features in these packstone layers, which therefore are interpreted as being turbidites. 
Table 1. Coring summary, Sites 629 and 630.

\begin{tabular}{|c|c|c|c|c|c|c|c|}
\hline $\begin{array}{l}\text { Core } \\
\text { no. }\end{array}$ & $\begin{array}{l}\text { Core } \\
\text { type }\end{array}$ & $\begin{array}{l}\text { Date } \\
\text { (Feb. } \\
\text { 1985) }\end{array}$ & Time & $\begin{array}{l}\text { Sub-bottom } \\
\text { depths } \\
\text { (m) }\end{array}$ & $\begin{array}{l}\text { Length } \\
\text { cored } \\
\text { (m) }\end{array}$ & $\begin{array}{l}\text { Length } \\
\text { recovered } \\
\text { (m) }\end{array}$ & $\begin{array}{l}\text { Percentage } \\
\text { recovered }\end{array}$ \\
\hline \multicolumn{8}{|l|}{ Hole 629A } \\
\hline 1 & $\mathrm{H}$ & 20 & 0001 & $0-6.9$ & 6.9 & 2.91 & 42 \\
\hline 2 & $\mathrm{H}$ & 20 & 0053 & $6.9-16.5$ & 9.6 & 1.66 & 17 \\
\hline 3 & $\mathrm{X}$ & 20 & 0230 & $6.9-16.5$ & 9.6 & 1.64 & 17 \\
\hline \multicolumn{8}{|l|}{ Hole $630 \mathrm{~A}$} \\
\hline 1 & $\mathrm{H}$ & 20 & 1320 & $0-8.6$ & 8.6 & 8.66 & 100 \\
\hline 2 & $\mathrm{H}$ & 20 & 1415 & $8.6-18.2$ & 9.6 & 10.11 & 105 \\
\hline 3 & H & 20 & 1500 & $18.2-27.8$ & 9.6 & 9.69 & 100 \\
\hline 4 & $\mathrm{H}$ & 20 & 1545 & $27.8-37.4$ & 9.6 & 9.33 & 97 \\
\hline 5 & $\mathrm{H}$ & 20 & 1615 & $37.4-47.0$ & 9.6 & 9.50 & 98 \\
\hline 6 & $\mathrm{H}$ & 20 & 1700 & $47.0-56.9$ & 9.9 & 9.38 & 94 \\
\hline 7 & H & 20 & 1730 & $56.9-66.3$ & 9.4 & 9.43 & 100 \\
\hline 8 & $\mathrm{H}$ & 20 & 1805 & $66.3-75.9$ & 9.6 & 9.49 & 98 \\
\hline 9 & $\mathrm{H}$ & 20 & 1845 & $75.9-85.7$ & 9.8 & 9.45 & 96 \\
\hline 10 & $\mathrm{H}$ & 20 & 1915 & $85.7-95.1$ & 9.4 & 9.55 & 101 \\
\hline 11 & $\mathrm{H}$ & 20 & 1945 & $95.1-104.7$ & 9.6 & 9.82 & 102 \\
\hline 12 & $\mathrm{H}$ & 20 & 2015 & $104.7-114.3$ & 9.6 & 9.66 & 100 \\
\hline 13 & H & 20 & 2030 & $114.3-123.9$ & 9.6 & 9.66 & 100 \\
\hline 14 & $\mathrm{H}$ & 20 & 2100 & $123.9-133.5$ & 9.6 & 9.80 & 102 \\
\hline 15 & $\mathrm{H}$ & 20 & 2130 & $133.5-143.1$ & 9.6 & 9.70 & 101 \\
\hline 16 & $\mathrm{H}$ & 20 & 2200 & $143.1-152.8$ & 9.7 & 9.38 & 96 \\
\hline 17 & $\mathrm{H}$ & 20 & 2315 & $152.8-162.4$ & 9.6 & 8.69 & 90 \\
\hline 18 & $\mathrm{H}$ & 21 & 0030 & $162.4-172.1$ & 9.7 & 8.77 & 90 \\
\hline 19 & $\mathrm{x}$ & 21 & 0212 & $171.9-183.6$ & 11.7 & 9.66 & 82 \\
\hline 20 & $\mathrm{x}$ & 21 & 0305 & $183.6-193.2$ & 9.6 & 8.60 & 89 \\
\hline 21 & $\mathrm{x}$ & 21 & 0349 & $193.2-202.9$ & 9.7 & 9.39 & 96 \\
\hline 22 & $\mathrm{x}$ & 21 & 0430 & $202.9-212.5$ & 9.6 & 1.22 & 12 \\
\hline 23 & $\mathrm{X}$ & 21 & 0510 & $212.5-221.9$ & 9.4 & 5.93 & 63 \\
\hline 24 & $\mathrm{X}$ & 21 & 0615 & $221.9-231.3$ & 9.4 & 5.32 & 56 \\
\hline 25 & $\mathrm{x}$ & 21 & 0715 & $231.3-240.9$ & 9.6 & 0.57 & 5 \\
\hline 26 & $\mathrm{x}$ & 21 & 0850 & $240.9-250.3$ & 9.4 & 9.42 & 100 \\
\hline \multicolumn{8}{|l|}{ Hole $630 \mathrm{~B}$} \\
\hline 1 & $\mathrm{H}$ & 21 & 1150 & $0-3.8$ & 3.8 & 3.77 & 99 \\
\hline 2 & $\mathrm{H}$ & 21 & 1345 & $3.8-13.4$ & 9.6 & 9.54 & 99 \\
\hline 3 & $\mathrm{H}$ & 21 & 1430 & $13.4-22.8$ & 9.4 & 9.51 & 101 \\
\hline 4 & $\mathrm{H}$ & 21 & 1515 & $22.8-32.5$ & 9.7 & 9.66 & 99 \\
\hline 5 & $\mathrm{H}$ & 21 & 1600 & $32.5-41.9$ & 9.4 & 9.55 & 101 \\
\hline 6 & H & 21 & 1630 & $41.9-51.5$ & 9.6 & 9.05 & 94 \\
\hline 7 & $\mathrm{H}$ & 21 & 1700 & $51.5-61.2$ & 9.7 & 9.31 & 95 \\
\hline 8 & $\mathrm{H}$ & 21 & 1745 & $61.7-70.8$ & 9.1 & 9.11 & 100 \\
\hline 9 & $\mathrm{H}$ & 21 & 1815 & $70.8-80.4$ & 9.6 & 10.04 & 104 \\
\hline \multicolumn{8}{|l|}{ Hole $630 \mathrm{C}$} \\
\hline 1 & $\mathrm{H}$ & 21 & 1942 & $0-9.3$ & 9.3 & 9.31 & 100 \\
\hline
\end{tabular}

${ }^{\mathrm{a}} \mathrm{H}=$ hydraulic piston; $\mathrm{X}=$ extended core barrel.

Forty percent of the interlayered sediment is a soft or stiff ooze; the other $60 \%$ consists of chalk. According to smear slide estimates, this material has a low foraminiferal content (15\%), a relatively high micrite content $(35 \%)$, and fairly abundant aragonite needles when compared with Subunit IC (see Fig. 2). The carbonate mineralogy shows $10 \%-15 \%$ aragonite in Unit II, which fits well (perhaps coincidentally) with the relatively high content of micrite and aragonite needles.

\section{Discussion}

Unit I ranges in age from late Miocene to Holocene ("Biostratigraphy" section, this chapter). The upper part of Unit I (Subunit IA) roughly corresponds to early to late Pleistocene and late Pliocene, Subunit IB to early Pliocene, and Subunit IC to very late Miocene and earliest Pliocene. Unit II was deposited only during the late Miocene and is coeval with Subunit IB in Hole 628A.
Study of Unit I suggests that bypassing of sandy turbidity currents through the closest gullies has occurred during the last 6 m.y., while ooze accumulated on the interfluve at an average sedimentation rate of $25 \mathrm{~m} / \mathrm{m}$.y. Rates of sedimentation were even higher, about $62 \mathrm{~m} / \mathrm{m} . \mathrm{y}$, during part of the Pliocene. The upper part of Unit I (Subunit IA) seems to correspond to the well-established glacial interval of the late Pliocene and the Pleistocene, a time when bank-derived aragonite seems to have been the largest. This tentative interpretation will have to be confirmed by detailed oxygen isotope stratigraphy and analyses of the clay and feldspar composition.

Unit II can be interpreted as a turbidite apron at the toe of the late Miocene gullied slope. Unit II in Hole 630A seems to correlate well with the turbidite-rich sequence of Subunit IC in Hole $628 \mathrm{~A}$. In conclusion, Site 630 provides a detailed record of the evolution of a gullied slope, prograding over its turbidite apron since late Miocene time. This site also gives an excellent 


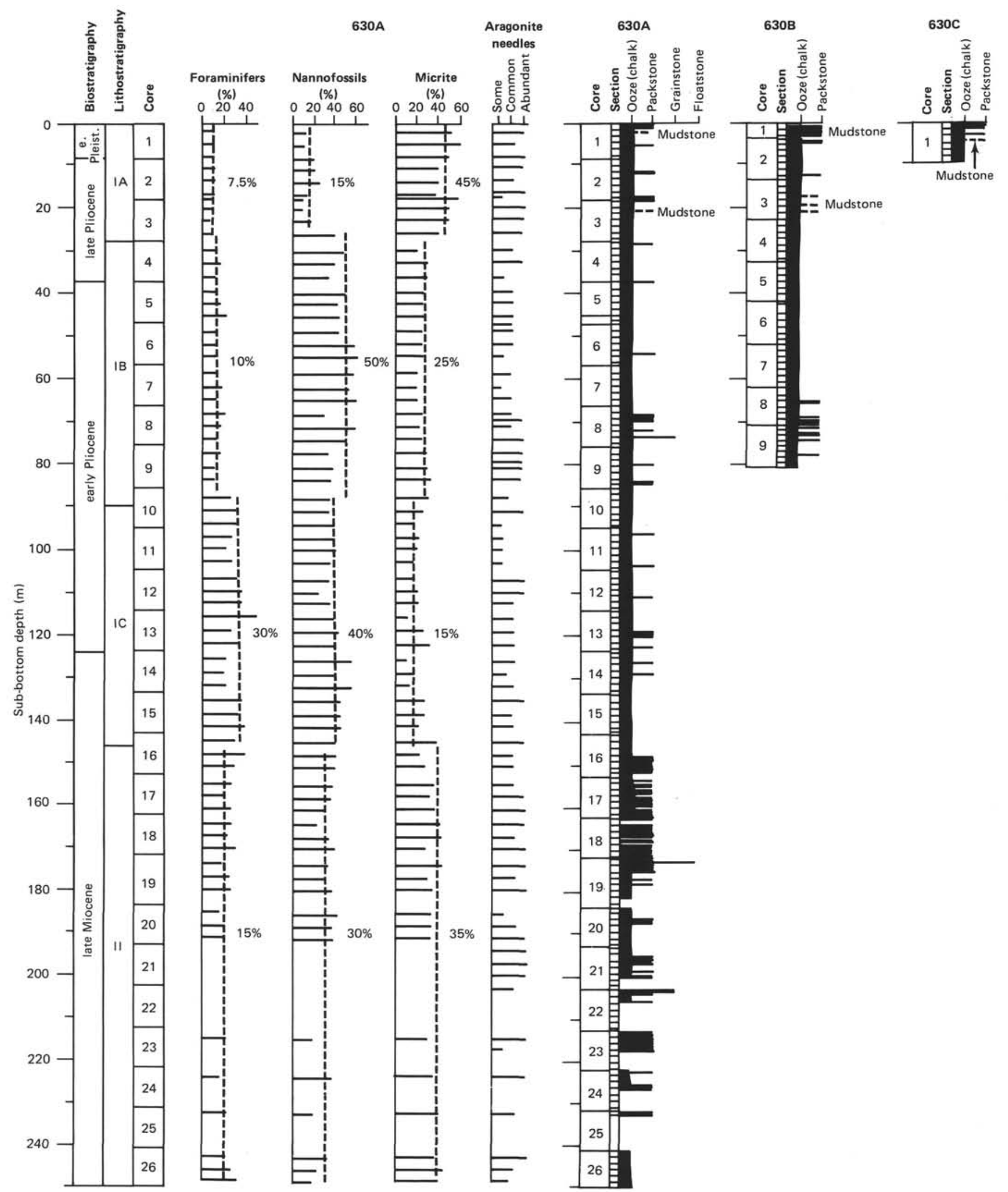

Figure 2. Comparison of sedimentary textures among Holes $630 \mathrm{~A}, 630 \mathrm{~B}$, and $630 \mathrm{C}$, and smear slide estimates of major components for Hole $630 \mathrm{~A}$. 
Table 2. Composition of lithologic units, Sites 629 and 630.

\begin{tabular}{|c|c|c|c|c|c|c|c|}
\hline \multirow{2}{*}{$\begin{array}{l}\text { Lithologic } \\
\text { unit } \\
\text { (subunit) }\end{array}$} & \multirow{2}{*}{$\begin{array}{l}\text { Sub-bottom } \\
\text { depth } \\
\text { (m) }\end{array}$} & \multicolumn{2}{|l|}{ Lithology } & \multicolumn{4}{|c|}{ Total percentage of other constituents } \\
\hline & & $\begin{array}{l}\text { Dominant } \\
\text { lithology }\end{array}$ & $\begin{array}{c}\text { Occurrence } \\
(\%)\end{array}$ & $\begin{array}{c}\text { Foraminifers } \\
(\%)\end{array}$ & $\begin{array}{c}\text { Nannofossils } \\
(\%)\end{array}$ & $\begin{array}{l}\text { Micrite } \\
(\%)\end{array}$ & $\begin{array}{c}\text { Aragonite } \\
(\%)\end{array}$ \\
\hline \multirow[t]{2}{*}{ I } & $0-146$ & $\begin{array}{l}\text { Calcareous ooze } \\
\text { (periplatform ooze) }\end{array}$ & 90 & & & & \\
\hline & & $\begin{array}{l}\text { Packstone layers } \\
\text { (turbidites) }\end{array}$ & 10 & 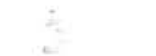 & & & \\
\hline IA & $0-28$ & & & 7.5 & 15 & 45 & $40-50$ \\
\hline IB & $28-90$ & & & 10 & 50 & 25 & $20-25$ \\
\hline IC & $90-146$ & & & 30 & 40 & 15 & 0 \\
\hline \multirow[t]{2}{*}{ II } & $146-250$ & Ooze and chalk & 60 & 15 & 30 & 35 & $10-15$ \\
\hline & & $\begin{array}{l}\text { Packstone layers } \\
\text { (turbidites) }\end{array}$ & 40 & & & & \\
\hline
\end{tabular}

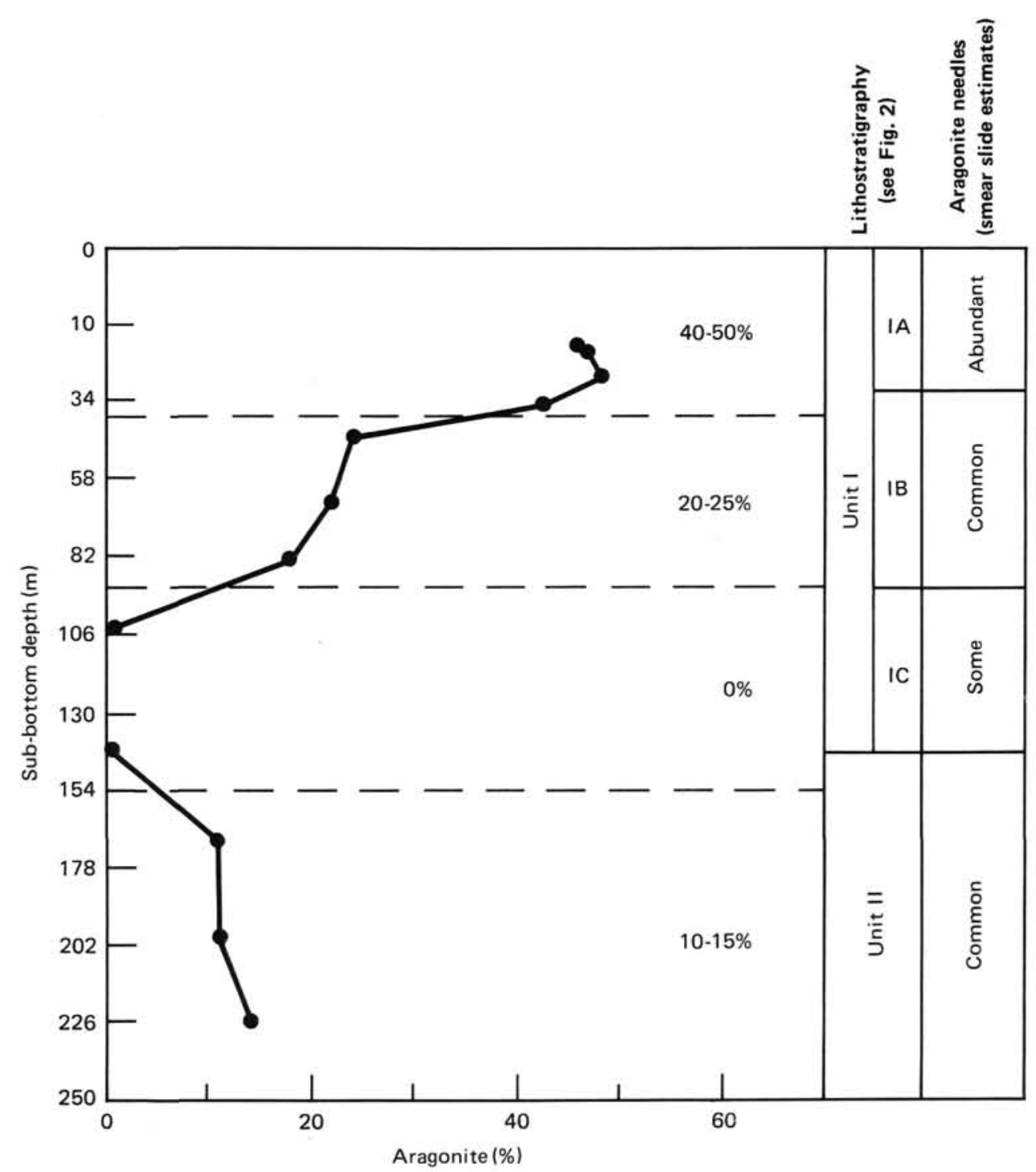

Figure 3. Aragonite content by $\mathrm{x}$-ray diffraction vs. sub-bottom depth for Hole 630A, and comparison of lithostratigraphy with the aragonite-needle content in smear slides. 


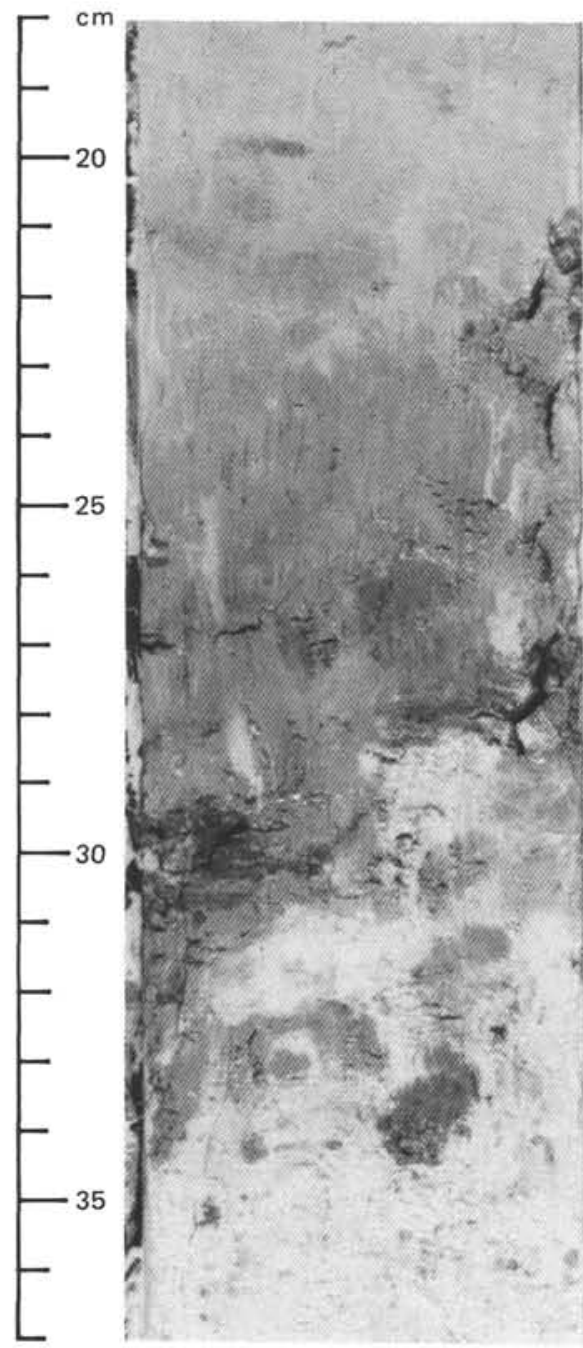

Figure 4. Clay-rich layers in Core 630A-3H-2, 23-29 cm.

record of the export of fine sediment by the Bahamas carbonate platform during the last $10 \mathrm{~m} . \mathrm{y}$.

\section{BIOSTRATIGRAPHY}

\section{Introduction}

Hole $629 \mathrm{~A}$ was drilled to a total depth of $27.1 \mathrm{~m}$ sub-bottom. Three cores containing coarse rubble were obtained (Cores 629A-1H, 629A-2H, and 629A-3X).

A nearly continuous upper Neogene-Quaternary section was recovered at Site 630. Calcareous nannofossils and planktonic foraminifers are generally well to moderately preserved throughout the thick section of periplatform oozes and chalks. Hole $630 \mathrm{~A}$ was drilled to a sub-bottom depth of $172.1 \mathrm{~m}$ (Cores $630 \mathrm{~A}-1 \mathrm{H}$ to $630 \mathrm{~A}-18 \mathrm{H}$ ) with the HPC, then continued to a total depth of $250.3 \mathrm{~m}$ (Cores 630A-19X to 630A-25X) with the XCB.

Unless otherwise specified, all samples examined for this report came from core catchers.

\section{Calcareous Nannofossils}

\section{Site 629}

Cores $629 \mathrm{~A}-1 \mathrm{H}$ through $629 \mathrm{~A}-3 \mathrm{H}$ contain assemblages from Zone NN21, which is correlated to the late Pleistocene and Holocene. Winnowing of the sediment or washing during core recovery depleted the nannofossil abundance in the sediment.

\section{Site 630}

Sections $630 \mathrm{~A}-1 \mathrm{H}-1$ through $630 \mathrm{~A}-1 \mathrm{H}-2$ contain abundant Emiliania huxleyi, indicating the top ( $E$. huxleyi acme) of Zone NN21. This zone correlates with the late Pleistocene to Holocene. The core catchers from Cores $630 \mathrm{~A}-1 \mathrm{H}$ and $630 \mathrm{~A}-2 \mathrm{H}$ contain mixed assemblages having both $E$. huxleyi (NN21) and Pseudoemiliania lacunosa (NN19 to NN16). This mixing is the result of either downhole contamination or reworking. Only strongly overgrown specimens of Cyclococcolithina macintyrei were observed, suggesting that these specimens were reworked. Therefore, the flora probably belongs to the younger part of the NN19, and the sediment is most likely Pleistocene.

Cores $630 \mathrm{~A}-3 \mathrm{H}$ and $630 \mathrm{~A}-4 \mathrm{H}$ contain assemblages composed of Discoaster pentaradiatus, Discoaster brouweri, and Discoaster surculus, as well as probable Pseudoemiliania lacunosa, all suggesting Zone NN16, which correlates with the earliest part of the late Pliocene. These assemblages continue downward from Core $630 \mathrm{~A}-5 \mathrm{H}$ through $630 \mathrm{~A}-8 \mathrm{H}$, adding Reticulofenestra pseudoumbilica and Discoaster asymmetricus in the lower sections. The presence or absence of Amaurolithus tricorniculatus (which differentiates NN14 from NN15) was difficult to ascertain. As a result, this interval is assigned to Zones NN14/15, which correlates with the early Pliocene. The absence of Discoaster asymmetricus and Discoaster quinqueramus in assemblages from Cores $630 \mathrm{~A}-9 \mathrm{H}$ through $630 \mathrm{~A}-13 \mathrm{H}$ indicates that this interval is from Zones NN12/13 (latest Miocene to early Pliocene). The occurrence of Discoaster quinqueramus in assemblages from Cores $630-14 \mathrm{H}$ through $630 \mathrm{~A}-21 \mathrm{X}$ indicates Zone NN11, although the assemblage in Core $630 \mathrm{~A}-16 \mathrm{H}$ is too poorly preserved to yield a definitive age determination. No stratigraphically important species have been observed in the core catchers below Core $630 \mathrm{~A}-21 \mathrm{X}$ because of poor preservation and very low nannofossil concentrations.

\section{Foraminifers}

\section{Site 629}

Three cores of upper Pleistocene sediments were recovered from Hole 629A. Planktonic foraminifers of the Globorotalia truncatulinoides Zone (N23) are abundant. A mixture of shelf and slope taxa characterizes the benthic-foraminiferal assemblages.

\section{Site 630}

A late Pleistocene age (Globorotalia truncatulinoides Zone, N23) is assigned to Core $630 \mathrm{~A}-1 \mathrm{H}$ on the basis of the occurrence of $G$. truncatulinoides and the pink variety of Globigerinoides ruber. A hiatus may separate Quaternary from upper Pliocene sediments in Core 630A-2H. The presence of Globorotalia miocenica and the absence of $G$. truncatulinoides and early Pliocene taxa suggest a late Pliocene age (Globorotalia miocenica and Globorotalia tosaensis Zones; N19 part/N21) for the base of Core 630A-2H (18.2 m sub-bottom). The upper Pliocene Globorotalia miocenica Zone (N19 part) is recognized in Cores 630A$3 \mathrm{H}$ and $630 \mathrm{~A}-4 \mathrm{H}$ (27.8 and $37.4 \mathrm{~m}$ sub-bottom), as indicated by the abundance of $G$. miocenica and the absence of early Pliocene species. The transition from upper to lower Pliocene occurs in Cores $630 \mathrm{~A}-5 \mathrm{H}$ and $630 \mathrm{~A}-6 \mathrm{H}$. Cores $630 \mathrm{~A}-7 \mathrm{H}$ through $630 \mathrm{~A}-13 \mathrm{H}$ (56.9 to $123.9 \mathrm{~m}$ sub-bottom) are early Pliocene in age and are assigned to the Globorotalia margaritae Zone (N18/ N19 part). Diagnostic taxa include $G$. margaritae, G. plesiotumida, Globigerina nepenthes, and Globoquadrina altispira (s.1.). Globorotalia juanai characterizes the transition from upper Miocene to lowest Pliocene and is present in Cores $630 \mathrm{~A}-18 \mathrm{H}$ through $630 \mathrm{~A}-12 \mathrm{H}$.

The late Miocene Neogloboquadrina acostaensis Zone (N16/ N17) is represented in Cores 630A-14H through 630A-26X 
(123.9-250.3 m sub-bottom). Neogloboquadrina acostaensis is virtually absent in Cores $630 \mathrm{~A}-14 \mathrm{H}$ and $630 \mathrm{~A}-15 \mathrm{H}$ but increases in abundance downhole. Globorotalia lenguaensis and G. merotumida occur sporadically in Cores $630 \mathrm{~A}-18 \mathrm{H}$ through $630 \mathrm{~A}$ 26X. Other characteristic species of the late Miocene include Globorotalia scitula, G. menardii, Globigerina nepenthes, and Globigerinoides extremus.

Benthic foraminifers indicative of bathyal depths are found throughout the Neogene and Quaternary section of Hole 630A. Displaced neritic taxa occur sporadically in the upper part of the drilled interval but increase appreciably in Cores $630 \mathrm{~A}-17 \mathrm{H}$ through 630A-26X. Larger foraminifers represented by badly preserved Amphistegina sp. are present in Core 630A-25X, CC.

\section{Summary}

Among the three sites of the slope transect north of Little Bahama Bank, Site 630 on the upper slope contains fewer larger foraminifers than do the other, deeper sites. In fact, from the Holocene to the upper Miocene section $(250 \mathrm{~m})$, only one sample $(630-25 \mathrm{X}, \mathrm{CC})$ yields very badly preserved Amphistegina. This apparent lack of platform-derived material is even more unusual because turbidites are present throughout the $104 \mathrm{~m}$ of upper Miocene sediment.

\section{SEDIMENT-ACCUMULATION RATES}

An abbreviated interval of Pleistocene sediments (Cores 630A$2 \mathrm{H}$ and $630 \mathrm{~A}-1 \mathrm{H})$ overlies a thick, continuous sequence of upper Miocene-Pliocene strata (Cores 630A-26X through 630A-3H) in Hole 630A (Fig. 5). A hiatus of as much as 1 or 2 m.y. may separate the Neogene and Quaternary, although additional shorebased study is needed for better delineation of the magnitude of this suspected stratigraphic gap. A similar break occurs at Site 628 , where at $146 \mathrm{~m}$ sub-bottom a facies change from ooze and turbidites below to ooze above occurs. An average sediment-accumulation rate of $27-28 \mathrm{~m} / \mathrm{m}$.y. characterizes the entire section drilled in Hole 630A. Rates in the Pliocene ooze section may range as high as $62 \mathrm{~m} / \mathrm{m} . \mathrm{y}$, , and rates in the Miocene turbidite unit are $27 \mathrm{~m} / \mathrm{m} . \mathrm{y}$. or higher.

\section{INORGANIC GEOCHEMISTRY}

\section{Interstitial-Water Studies}

Concentrations of calcium and magnesium at Site 630 exhibit trends similar to those seen at Sites 626,627 , and 628 (Tables 3 and 4). Values of Ca gradually increase from their surface-seawater levels, whereas $\mathrm{Mg}$ concentrations decrease (see Fig. 6). The most marked change in these two elements occurs between surface seawater and water obtained from the first core. To investigate this gradient further, water samples were taken from every section in Core $630 \mathrm{C}-1 \mathrm{H}$ over the top $9 \mathrm{~m}$. Results of this investigation (see Fig. 7) confirm trends seen in previous holes. However, whereas increases in the $\mathrm{Ca}$ concentration were gradual over this depth, investigations of Hole $630 \mathrm{C}$ showed that $\mathrm{Mg}$ levels exhibited a sharp decrease over a small interval. Either diagenetic processes affecting the $\mathrm{Mg}$ concentration of interstitial waters occur rapidly, or surface waters are significantly different in $\mathrm{Mg}$ concentration from water immediately above the sediment/seawater interface. In assessing these scenarios, it is useful to normalize the concentration of $\mathrm{Ca}^{2+}$ and $\mathrm{Mg}^{2+}$ to the $\mathrm{Cl}^{-}$content. These values show that although the $\mathrm{Mg} / \mathrm{Cl}$ ratio of surface water is similar to the first sediment sample of Hole $630 \mathrm{C}$, the $\mathrm{Ca} / \mathrm{Cl}$ ratio of pore water is much higher. This difference is probably a result of the low $\mathrm{Ca} / \mathrm{Cl}$ ratio of surface waters rather than of any differential diagenetic reactions occurring in the sediments that may cause covariant trends.

\section{Sites 627, 628, and 630: Summary}

As discussed in the preceding section, interstitial waters from Sites 627,628 , and 630 exhibited similar $\mathrm{Ca}$ and $\mathrm{Mg}$ gradient trends. However, the magnitude of these gradients shows a constant change from the deeper site, Hole $627 \mathrm{~A}$, to the shallower site, Hole 630A (see Tables 5 and 6). The percentage of change in these gradients is much larger than the relative difference in water depth between the three sites (see "Operations Summary," this chapter, and Site 627 chapter, this volume). For example, the gradient in Hole $627 \mathrm{~A}$ over the top $250 \mathrm{~m}$ is $5.1 \times 10^{-2}$ $\mathrm{mmol} / \mathrm{L} / \mathrm{m}$, compared with a gradient in Hole $630 \mathrm{~A}$ over the same interval of $2.6 \times 10^{-2} \mathrm{mmol} / \mathrm{L} / \mathrm{m}$ (the normalization to $\mathrm{Cl}^{-}$does not significantly change these gradients). The Ca gradient cannot be explained by pressure alone but must result from diffusion of pore waters depleted in $\mathrm{Mg}$ and enriched in $\mathrm{Ca}$ from an underlying unit. The large difference in $\mathrm{Ca}$ gradients is therefore probably not a result of variations in sedimentation rates between the sites (see "Sedimentology" section, this chapter, and Site 627 chapter, this volume), because $\mathrm{Ca}$ concentrations reported at DSDP sites containing large amounts of carbonate (such as Site 245; Gieskes et al., 1981) show concentrations typically of $30 \mathrm{mmol} / \mathrm{L}$ adjacent to oceanic basalts. In Hole $627 \mathrm{~A}$, however, $\mathrm{Ca}$ concentrations of $35 \mathrm{mmol} / \mathrm{L}$ were reported within the Cenomanian marl section, which is at least $1 \mathrm{~km}$ above basement. This suggests that the Cenomanian interval, which is rich in igneous and terrigenous materials, may influence the $\mathrm{Ca}$ rise and $\mathrm{Mg}$ depletion in the overlying sediments. Using the difference in gradients between Sites 627 and 630 and assuming that the Cenomanian is indeed the source of $\mathrm{Ca}$, we can estimate that approximately $600 \mathrm{~m}$ of sediments lies above the Cenomanian at Hole 630 . This is the approximate thickness of sediments estimated from seismic profiles (see "Seismic Stratigraphy" section, this chapter).

A further important observation made at the three sites off Little Bahama Bank, as well as at Site 626 , is the apparent absence of significant amounts of sulfate depletion in the interstitial pore waters (Figs. 8 and 9). This lack of depletion may be a result of the low initial amounts of organic matter, the low sedimentation rates, and/or an external source of sulfate ions.

\section{X-Ray Studies}

Sediments from Site 630 can be divided into two units, according to changes in the percentage of aragonite and calcite (see Figs. 10-12). The uppermost unit, corresponding to the Pleistocene and the lower to the upper(?) Pliocene section, is characterized by amounts of aragonite greater than $40 \%$. Beneath this interval, aragonite content falls to levels of between $0 \%$ and $20 \%$. Dolomite forms a small but persistent proportion of the sediments throughout Hole $630 \mathrm{~A}$, yet shows no consistent pattern with depth or age (see Tables 7-9).

High-Mg calcite was detected only in the top $5 \mathrm{~m}$ of the section (Table 9). Its disappearance may be attributed to either a change of sedimentation patterns or a removal through diagenetic processes.

\section{Summary of X-Ray Data: Sites 627, 628, and 630}

In all three sites across the Little Bahama Bank transect, consistent changes were visible in the proportions of aragonite, calcite, dolomite, and quartz (see Fig. 13). The first change correlatable between the three sites occurs in the Pleistocene section, the uppermost part of which is typified by low aragonite concentrations. Proportions of aragonite increase downhole and reach a maximum at the Pliocene-Pleistocene boundary. The Pliocene is characterized by a sudden reduction in the amount of aragonite from approximately $70 \%$ to between $0 \%$ and $20 \%$ toward 


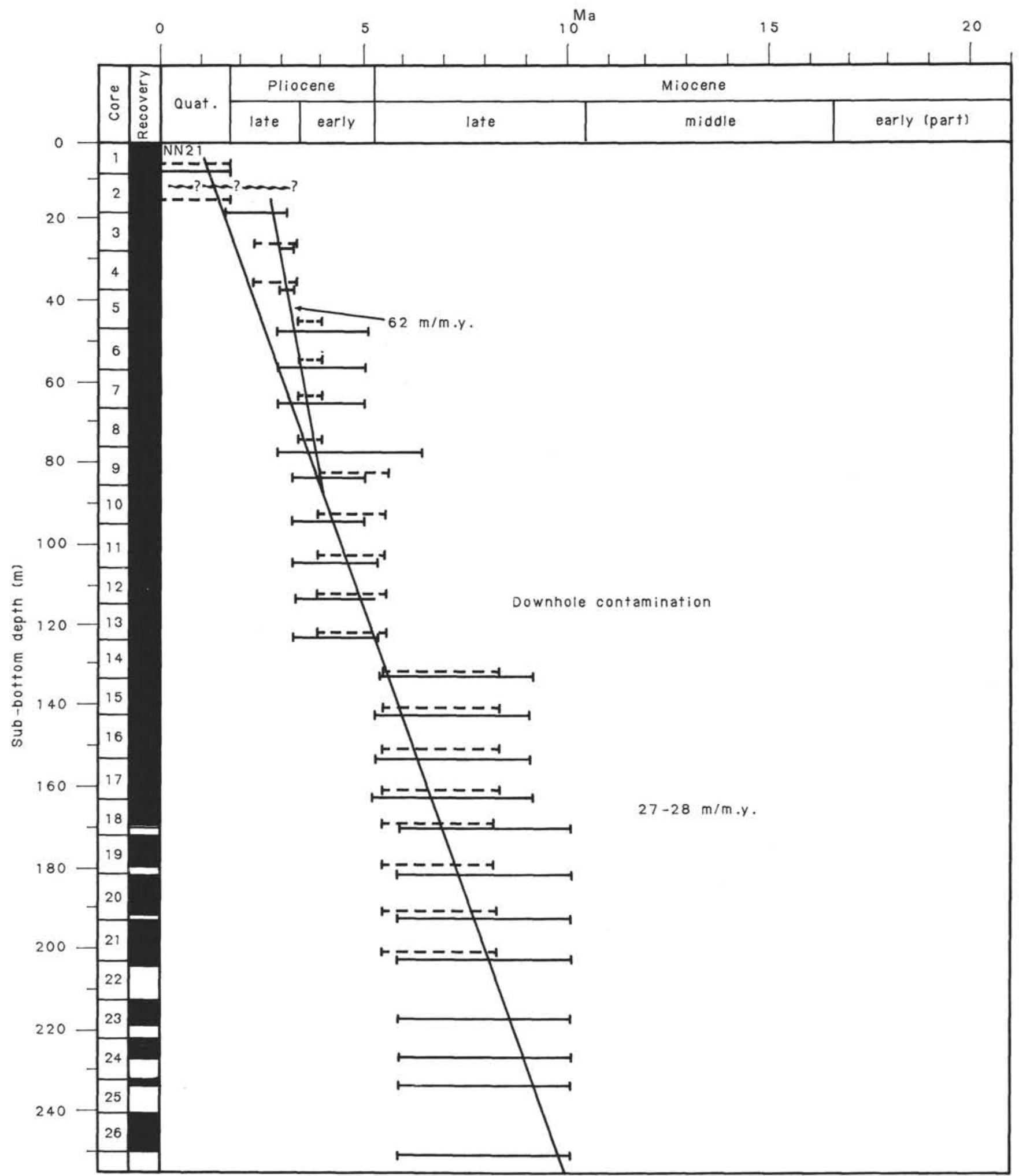

Figure 5. Sediment-accumulation rates, Site 630.

the start of the Miocene section. The third unit, present in all three holes, extends downward through the Miocene to the upper(?) Oligocene and also contains aragonite but in reduced and somewhat variable amounts (see Fig. 13). Absent at Site 630, the Oligocene in Holes 627 and 628 consists predominantly of low-Mg calcite and a small amount of quartz.
The cause of the decline in aragonite content near the surface at these three sites is unknown; perhaps because of the proximity to the surface, it is not primarily diagenetic. In the PliocenePleistocene, the changes in mineralogy are consistent with a reduction in the transport of platform sediment and a general trend from distal to oceanic slope facies. The appearance of 
Table 3. Analyses of interstitial waters from Hole 630A.

\begin{tabular}{cccccccc}
\hline $\begin{array}{c}\text { Sub-bottom } \\
\text { depth } \\
(\mathrm{m})\end{array}$ & $\mathrm{pH}$ & $\begin{array}{c}\text { Alkalinity } \\
(\mathrm{meq} / \mathrm{kg})\end{array}$ & $\begin{array}{c}\text { Salinity } \\
(\%)\end{array}$ & $\begin{array}{c}\text { Chlorinity } \\
(\% 0)\end{array}$ & $\begin{array}{c}\mathrm{Ca} \\
(\mathrm{mmol} / \mathrm{L})\end{array}$ & $\begin{array}{c}\mathrm{Mg} \\
(\mathrm{mmol} / \mathrm{L})\end{array}$ & $\begin{array}{c}\mathrm{SO}_{4} \\
(\mathrm{mmol} / \mathrm{L})\end{array}$ \\
\hline Surface seawater & 8.21 & 2.41 & 36.2 & 21.05 & 10.43 & 58.00 & 29.48 \\
7.4 & 7.65 & 3.00 & 35.0 & 20.81 & 11.44 & 52.87 & 25.05 \\
16.0 & 7.67 & 2.89 & 35.2 & 20.28 & 12.03 & 52.45 & 28.95 \\
25.6 & 7.72 & 3.09 & 35.1 & 19.27 & 11.78 & 52.65 & 29.08 \\
35.2 & 7.80 & 3.29 & 35.0 & 20.18 & 11.57 & 54.39 & 28.54 \\
44.8 & 7.63 & 3.08 & 35.1 & 20.56 & 12.25 & 53.12 & 28.81 \\
64.3 & 7.55 & 2.99 & 35.7 & 20.07 & 12.52 & 52.82 & 28.78 \\
83.3 & 7.35 & 3.41 & 35.9 & 20.84 & 14.30 & 50.71 & 27.38 \\
112.1 & 7.47 & 3.80 & 36.2 & 20.63 & 14.97 & 49.81 & 26.93 \\
140.9 & 7.36 & 4.05 & 37.0 & 21.16 & 14.64 & 48.96 & 27.49 \\
169.8 & 7.43 & 4.22 & 37.5 & 21.82 & 16.58 & 50.55 & 29.08 \\
200.6 & 7.51 & 4.69 & 37.8 & 21.58 & 16.20 & 50.93 & 25.68 \\
224.8 & 7.52 & 5.07 & 39.6 & 21.33 & 17.07 & 51.36 & 27.31 \\
\hline
\end{tabular}

Table 4. Analyses of interstitial waters from Hole 630C.

\begin{tabular}{cccccccc}
\hline $\begin{array}{c}\text { Sub-bottom } \\
\text { depth } \\
(\mathrm{m})\end{array}$ & $\mathrm{pH}$ & $\begin{array}{c}\text { Alkalinity } \\
(\mathrm{meq} / \mathrm{kg})\end{array}$ & $\begin{array}{c}\text { Salinity } \\
(\% 00)\end{array}$ & $\begin{array}{c}\text { Chlorinity } \\
(\% 00)\end{array}$ & $\begin{array}{c}\mathrm{Ca} \\
(\mathrm{mmol} / \mathrm{L})\end{array}$ & $\begin{array}{c}\mathrm{Mg} \\
(\mathrm{mmol} / \mathrm{L})\end{array}$ & $\begin{array}{c}\mathrm{SO}_{4} \\
(\mathrm{mmol} / \mathrm{L})\end{array}$ \\
\hline 1.45 & 7.75 & 3.03 & 34.8 & 19.72 & 10.74 & 53.92 & 28.49 \\
2.95 & 7.70 & 2.87 & 34.8 & 19.34 & 10.85 & 53.72 & 34.17 \\
4.45 & 7.62 & 2.78 & 34.8 & 20.00 & 10.78 & 53.85 & 23.24 \\
5.95 & 7.62 & 2.89 & 35.0 & 20.72 & 10.97 & 52.51 & 31.72 \\
7.45 & 7.65 & 3.08 & 35.0 & 20.14 & 11.42 & 51.94 & 32.00 \\
8.95 & 7.61 & 2.85 & 35.2 & 20.49 & 11.50 & 52.69 & 32.93 \\
\hline
\end{tabular}

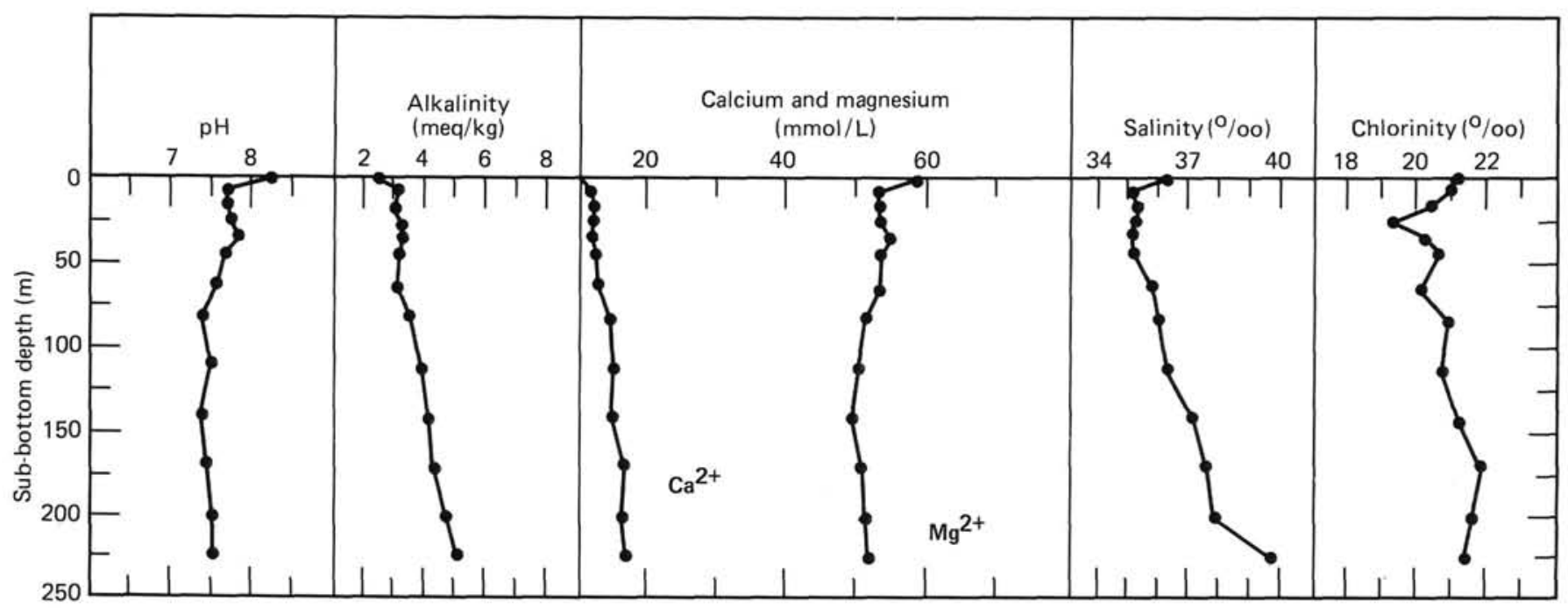

Figure 6. Summary of interstitial-water analyses, Hole 630A.

quartz in the lower Oligocene sediments could indicate the influence of deep oceanic currents in this area at that time.

The dolomite, typically moderately calcian (45-47 mol\% $\mathrm{MgCO}_{3}$ ), found in these sediments may be either detrital or diagenetic and occurs only within the Quaternary and Tertiary of Holes 627 and 628 to the Pleistocene and late Pliocene. In contrast, dolomite is ubiquitously distributed within Hole 630. Dolomite is also present in Albian rocks recovered from Hole 627B, although these rocks are clearly of a different origin than those of the Pliocene-Pleistocene occurrences.

\section{Carbonate-Bomb Data}

The percentage of carbonate was generally significantly lower at Site 630 than at either Site 627 or 628 (Fig. 14 and Table 10).
Although this may be a result of the proximal nature of the site, it should also be recognized that extremely rough surface conditions prevailed during drilling, making accurate weighing impossible. Results are therefore subject to confirmation by further shore-based studies.

\section{ORGANIC GEOCHEMISTRY}

Twenty-three rock samples were taken from Hole 630A for Rock-Eval analysis (see Figs. 15-18). The lithology consists essentially of periplatform carbonate ooze (late Miocene to Holocene).

The organic material, as in most of the Neogene-Holocene sites investigated on Leg 101, consists of low amounts of detri- 

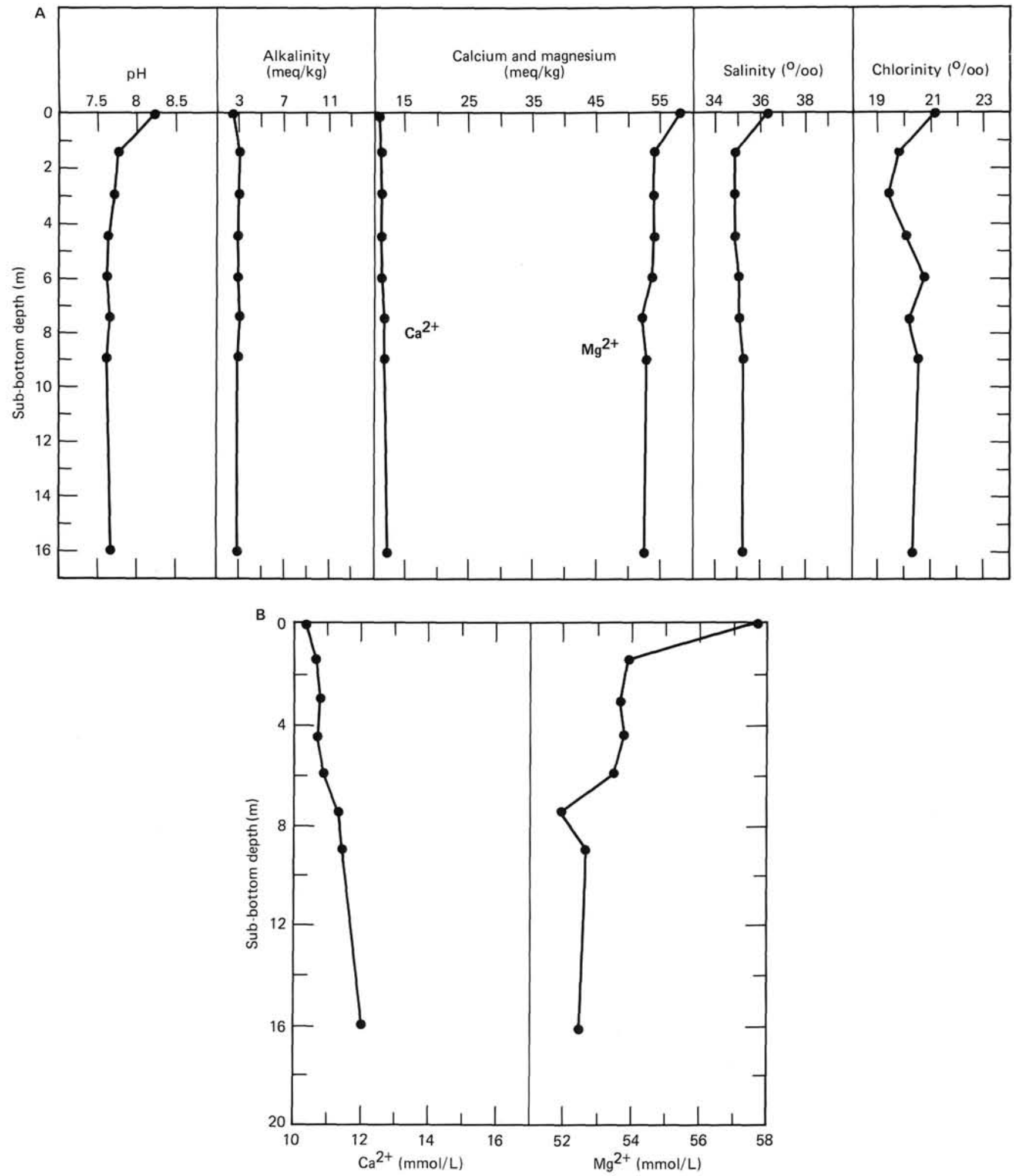

Figure 7. A. Summary of interstitial-water analyses, Hole $630 \mathrm{C}$. B. Interstitial $\mathrm{Ca}^{2+}$ and $\mathrm{Mg}^{2+}$ concentrations, Hole $630 \mathrm{C}$.

tal, oxidized, terrestrial organic matter (see Fig. 16). $\mathrm{T}_{\max }$ investigations showed a great mixture of material of differing maturities and probably different provenances (see Fig. 17).

An increased lipid component was somewhat indicated in the kerogen of the lower part of Unit II (late Miocene ooze and turbidites, see "Sedimentology" section, this chapter; Fig. 18).

\section{PALEOMAGNETISM}

Hole 630A yielded an expanded Pliocene and upper Miocene sedimentary section that may be useful for magnetostratigraphic studies and their correlation with other contemporary phenomena. However, the material recovered from Hole $630 \mathrm{~A}$ was 
Table 5. Summary of calcium gradients, Sites 627,628 , and 630.

\begin{tabular}{lcc}
\hline Site & $\begin{array}{c}10-\mathrm{m} \\
\text { sub-bottom } \\
\text { depth }\end{array}$ & $\begin{array}{c}250-\mathrm{m} \\
\text { sub-bottom } \\
\text { depth }\end{array}$ \\
\hline 627 & 7.5 & $5.1 \times 10^{-2}$ \\
628 & 14.0 & $3.2 \times 10^{-2}$ \\
630 & 13.5 & $2.6 \times 10^{-2}$ \\
\hline${ }^{2}$ Units expressed in mmol L $\mathrm{L}^{-1}$ \\
$\mathrm{~m}^{-1}$.
\end{tabular}

Table 6. Summary of magnesium gradients, Sites 627,628 , and $630 .^{a}$

\begin{tabular}{lcc}
\hline Site & $\begin{array}{c}\text { 10-m } \\
\text { sub-bottom } \\
\text { depth }\end{array}$ & $\begin{array}{c}\text { 250-m } \\
\text { sub-bottom } \\
\text { depth }\end{array}$ \\
\hline 627 & -53 & $\mathrm{~b}-2 \times 10^{-2}$ \\
628 & -73 & $-3 \times 10^{-2}$ \\
630 & -69 & $-1 \times 10^{-2}$ \\
\hline${ }^{\text {a Units }}$ \\
$\mathrm{m}^{-1}$ expressed in mmol $\mathrm{L}^{-1}$ \\
${ }^{\mathrm{D}}$ Data averaged over entire core \\
depth.
\end{tabular}

primarily calcareous ooze, which seemed unlikely to contain a magnetization of sufficient strength to be detectable by the shipboard Molspin spinner magnetometer. Consequently, only seven $7-\mathrm{cm}^{3}$ oriented samples were taken from two cores to aid in determining whether or not further sampling was warranted. A detailed paleomagnetic analysis of these cores was deferred until a later date contingent on the results of these sample analyses and on the usefulness of paleomagnetic data from the same types of sediments in other holes from Leg 101.

Because the magnetic-susceptibility measurements in Hole $628 \mathrm{~A}$ suggested that very little magnetic material would be in the sediments at Site 630 , the number of measurements taken from Hole 630A cores was reduced. Only Sections 2, 4, and 6 of each core were measured. As in Hole $628 \mathrm{~A}$, the susceptibility shows virtually no variation from a value of approximately -0.4 $\times 10^{-6} \mathrm{G} / \mathrm{Oe}$. However, unlike those for the previous holes, the susceptibility vs. depth plot shows few large amplitude spikes (Fig. 19). This is undoubtedly the effect of the exclusion of the data from the first section of each core that commonly appears to be contaminated with metallic flakes.

\section{PHYSICAL PROPERTIES}

Physical-property measurements were made on sediment recovered from Site 630A (see Table 11) as described in the "Introduction and Explanatory Notes" (this volume).

\section{Compressional Wave Velocity}

Compressional wave velocities measured on samples removed from the core liner average $1700 \mathrm{~m} / \mathrm{s}$ and show little variation with increasing depth (Fig. 20).

Compressional wave velocities measured on sediment in the core liner (three measurements each on Sections 2, 4, and 6 of each core) show two zones of constant velocity. From 0 to $150 \mathrm{~m}$ sub-bottom, values average $1700 \mathrm{~m} / \mathrm{s}$. Between 150 and $200 \mathrm{~m}$ sub-bottom, velocities average $1800 \mathrm{~m} / \mathrm{s}$.

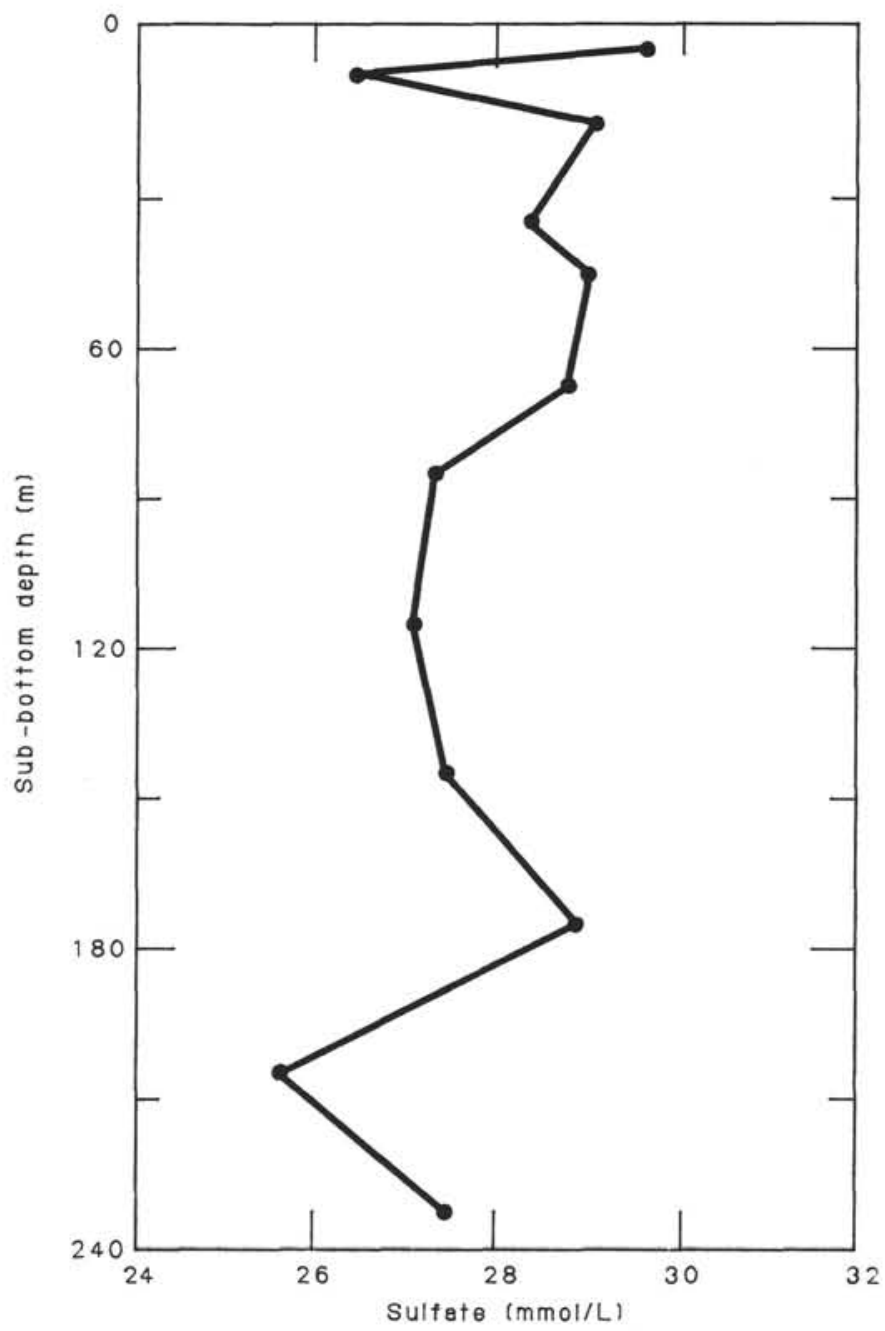

Figure 8. Interstitial-sulfate concentrations, Hole 630A.

\section{Wet-Bulk Density, Porosity, and Water Content}

Density values increase steadily with increasing depth from $1.6 \mathrm{~g} / \mathrm{cm}^{3}$ at $1.5 \mathrm{~m}$ sub-bottom to $1.9 \mathrm{~g} / \mathrm{cm}^{3}$ at $250 \mathrm{~m}$ sub-bottom. There is very little variation around the mean (Fig. 20).

Porosity values decrease with depth from $60 \%$ at $1.5 \mathrm{~m}$ subbottom to $50 \%$ at $250 \mathrm{~m}$ sub-bottom. The two low values of $40 \%$ at $85 \mathrm{~m}$ and $40 \%$ at $220 \mathrm{~m}$ are single samples.

Water content decreases regularly with depth from $53 \%$ at $1.5 \mathrm{~m}$ sub-bottom to $35 \%$ at $250 \mathrm{~m}$ sub-bottom. The decrease in water content correlates with the decrease in porosity and increase in density.

\section{Thermal Conductivity}

Conductivity increases regularly and slowly with increasing depth from $2.7 \times 10^{-3} \mathrm{cal} \times{ }^{\circ} \mathrm{C}^{-1} \times \mathrm{cm}^{-1} \times \mathrm{s}^{-1}$ at $1 \mathrm{~m}$ subbottom to $3 \times 10^{-3} \mathrm{cal} \times{ }^{\circ} \mathrm{C}^{-1} \times \mathrm{cm}^{-1} \times \mathrm{s}^{-1}$ at $250 \mathrm{~m}$ subbottom. Values vary little except in the deepest parts of the hole (more than $240 \mathrm{~m}$ sub-bottom) where measurements were made on core catchers.

\section{Shear Strength}

Shear strength increases slowly and regularly with increasing depth from $4 \mathrm{kPa}$ at $1.5 \mathrm{~m}$ sub-bottom to $7 \mathrm{kPa}$ at $250 \mathrm{~m}$ sub-bottom. 


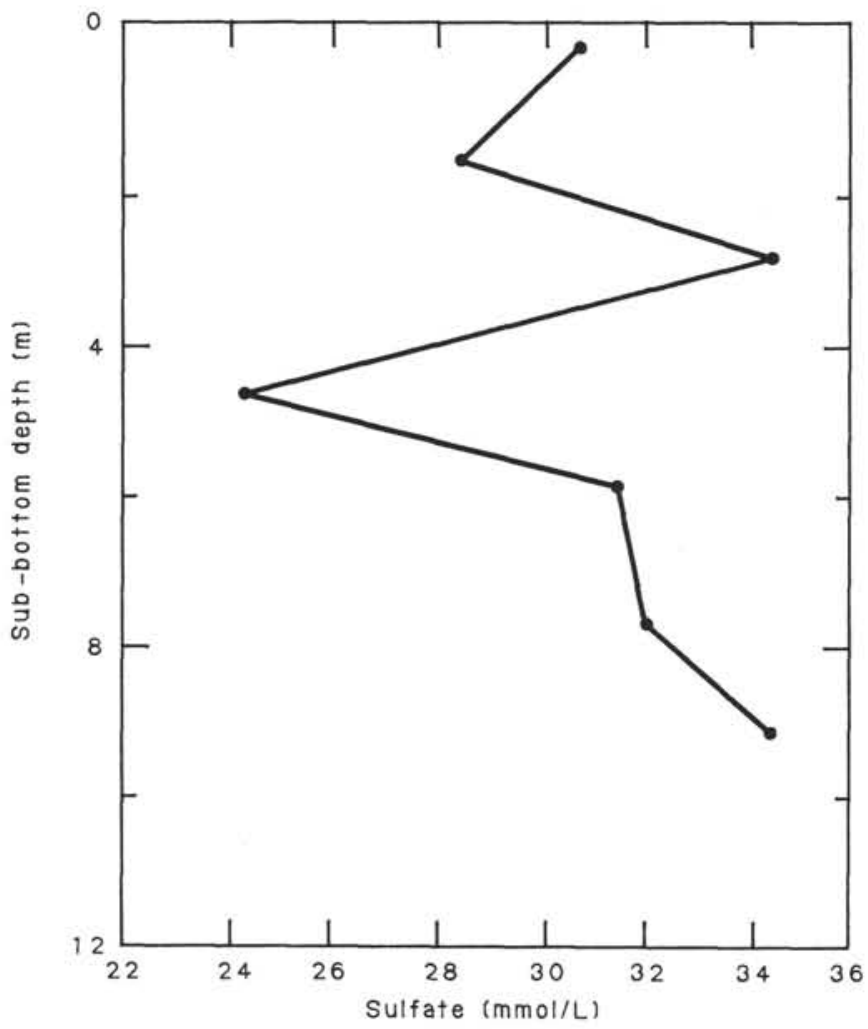

Figure 9. Interstitial-sulfate concentrations, Hole $630 \mathrm{C}$.

\section{Discussion}

Physical-property parameters reflect general trends with depth, as would be expected of a homogeneous lithologic section having increasing overburden pressure. Only compressional wave velocity measurements made within the core liner show a change in overall trend. At $148 \mathrm{~m}$ sub-bottom, higher velocity averages $(1800 \mathrm{~m} / \mathrm{s})$ correlate with an increase in induration of the background sedimentation and an increase in number of turbidite layers.

\section{SEISMIC STRATIGRAPHY}

\section{Introduction}

Site 630 completely sampled the top $200-300 \mathrm{~m}$ of the upper part of an accretionary carbonate slope. Because this site is located on an interfluve between gullies (see "Operations Summary," this chapter), regional seismic stratigraphic correlations could be made with confidence only along the trend of the interfluve (i.e., upslope/downslope) or laterally within it (i.e., along the slope contours). Despite this complexity, we propose that a sequence boundary sampled at the bottom of Site 630 immediately overlies the B/C sequence boundary at Site 628 approximately five $\mathrm{n}$. mi downslope.

\section{Seismic Correlations: Hole 630A}

Site 630 lies just west of the intersection of site-survey lines LBB-05 and LBB-10 (Fig. 1, this chapter). Two sequence boundaries are recognized in the upper $300 \mathrm{~m}$ of section at this intersection. The upper surface is discernible only on LBB-10, occurring at $0.06 \mathrm{~s}$ sub-bottom (Fig. 21). At an interval velocity of $1.75 \mathrm{~km} / \mathrm{s}$, equal to that used for upper sequences on LBB-18 at Sites 627 and 628 , the converted depth is $52 \mathrm{~m}$. Neither a lithologic boundary nor a biostratigraphic hiatus exists within this depth range in Hole 630A. However, this seismic boundary ap-

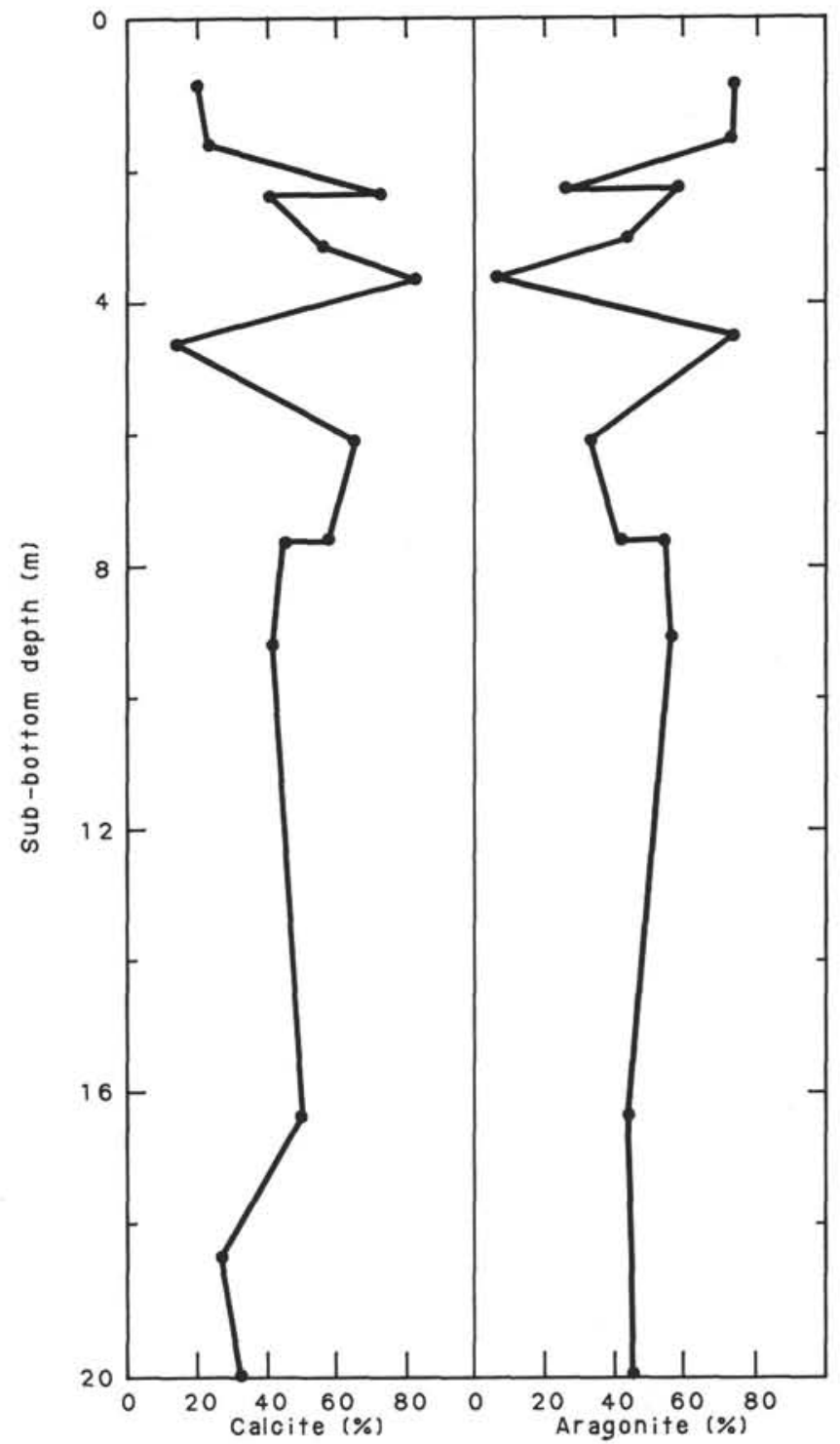

Figure 10. Percentages of calcite and aragonite from Holes 630A and $630 \mathrm{C}$ as measured by $\mathrm{x}$-ray diffraction for the top $20 \mathrm{~m}$.

pears to intersect the seafloor downslope of LBB-05 (Fig. 21), suggesting that its sub-bottom depth may decrease rapidly with increasing water depth. Hole $630 \mathrm{~A}$ is slightly downslope of the line intersection (see "Operations Summary," this chapter). Perhaps this upper sequence boundary was produced by the same erosional episode that caused an abbreviation of the Quaternary sequence between Cores 630A-1H and 630A-2H (see "Biostratigraphy" section, this chapter).

The deeper sequence boundary visible on LBB-10 is a prominent impedance contrast and apparent unconformity, which occurs at $0.28 \mathrm{~s}$ sub-bottom and $0.26 \mathrm{~s}$ sub-bottom on LBB- 05 , in both cases at the base of an acoustically transparent interval (Figs. 21 and 22). If a compressional wave velocity of $1.75 \mathrm{k} / \mathrm{s}$ is used to convert the entire overlying section from traveltime to depth, the sequence boundary occurs at $228-245 \mathrm{~m}$ sub-bottom, within a zone of poor recovery in Hole 630A (Cores 630A-22X through $630 \mathrm{~A}-26 \mathrm{X}, 202.9-240.9 \mathrm{~m}$ sub-bottom). If this poor recovery is caused by either lithologic or diagenetic changes, then a possible correlation with those changes and the acoustic horizon is suggested. 


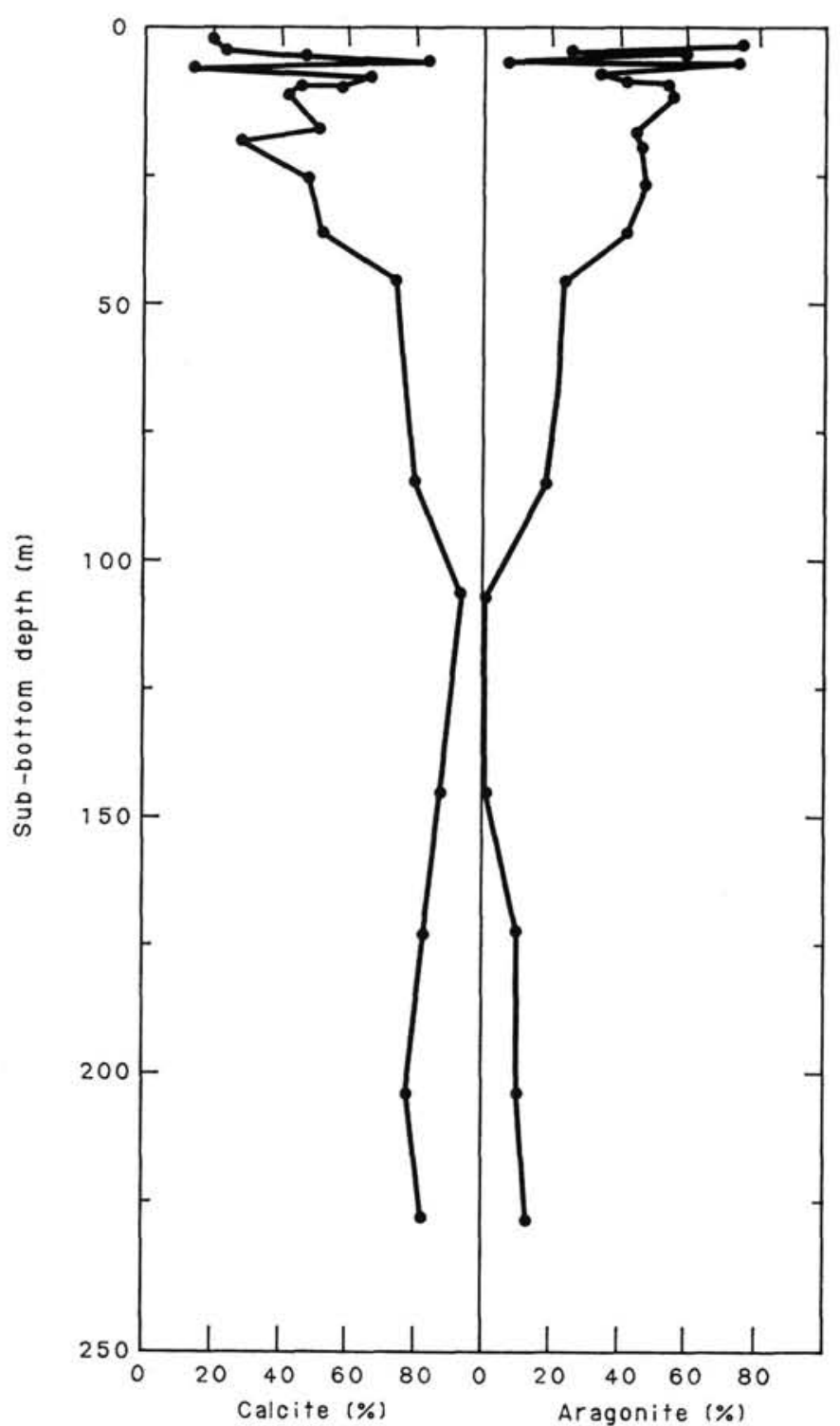

Figure 11. Percentages of calcite and aragonite from Holes 630A and $630 \mathrm{C}$ as measured by $\mathrm{x}$-ray diffraction.

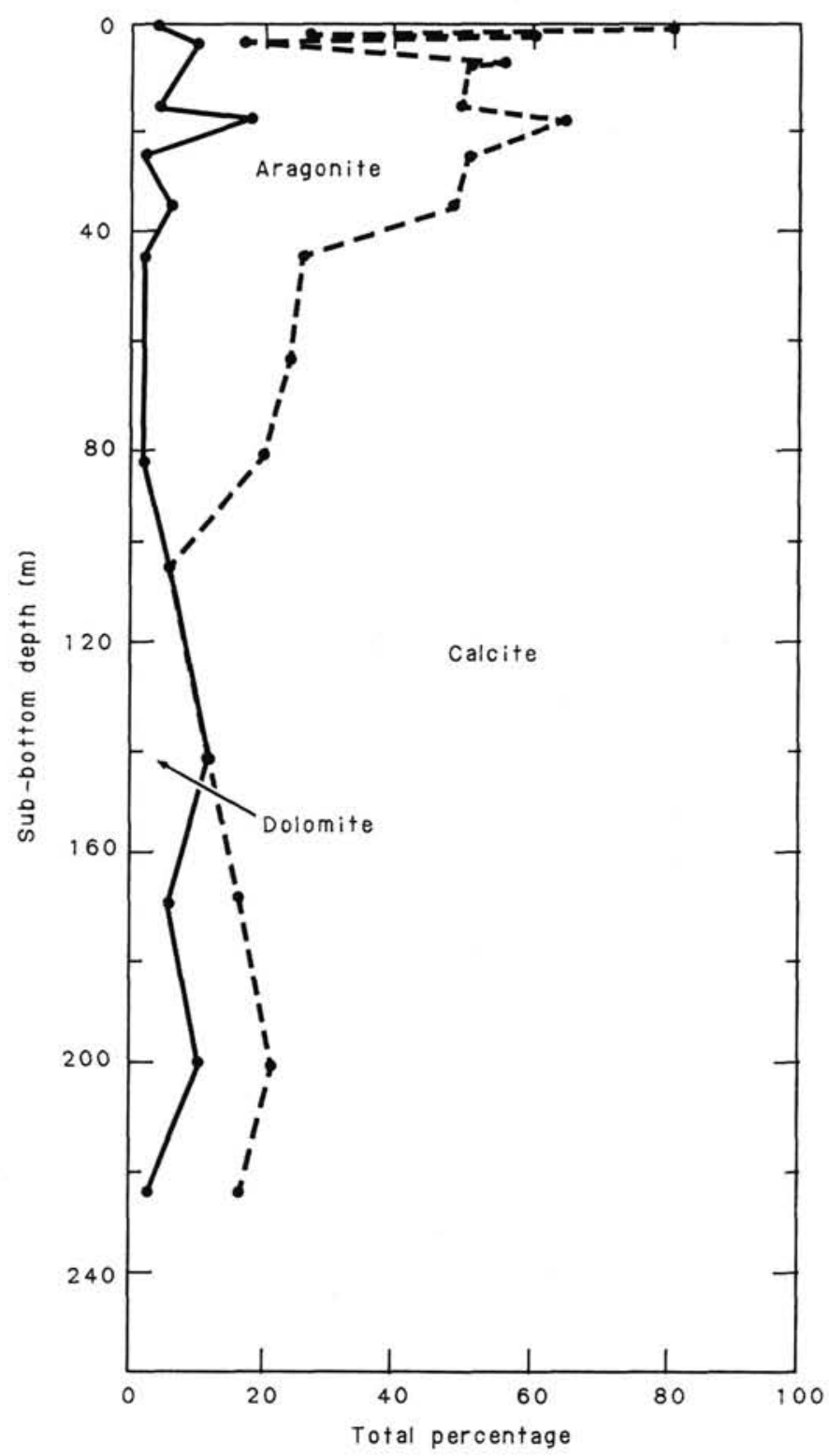

Figure 12. X-ray data, Site 630.

Table 7. X-ray analyses of samples from Hole 630A.

\begin{tabular}{cccccl}
\hline $\begin{array}{c}\text { Sub-bottom } \\
\text { depth } \\
(\mathrm{m})\end{array}$ & $\begin{array}{c}\text { Calcite } \\
(\%)\end{array}$ & $\begin{array}{c}\text { Aragonite } \\
(\%)\end{array}$ & $\begin{array}{c}\text { Dolomite } \\
(\%)\end{array}$ & $\begin{array}{c}\text { Quartz } \\
(\%)\end{array}$ & $\begin{array}{c}\text { Other minerals } \\
\text { present }\end{array}$ \\
\hline 0.7 & 21 & 76 & 4 & 0 & Mixed-layer illite-montmorillonite \\
2.2 & 77 & 27 & 0 & 0 & Mixed-layer illite-montmorillonite \\
2.22 & 41 & 59 & 0 & 0 & Mixed-layer illite-montmorillonite \\
3.5 & 83 & 7 & 10 & 0 & Mixed-layer illite-montmorillonite \\
7.4 & 45 & 55 & 0 & 0 & \\
8.1 & 50 & 50 & 0 & 0 & \\
16.0 & 51 & 45 & 4 & 0 & Plagioclase \\
18.2 & 28 & 46 & 18 & 0 & \\
25.6 & 48 & 48 & 2 & 0 & Palygorskite \\
35.2 & 52 & 42 & 6 & 0 & \\
44.8 & 74 & 24 & 2 & 0 & Mixed-layer illite-montmorillonite \\
64.3 & 77 & 22 & 2 & 0 & \\
83.3 & 80 & 18 & 2 & 0 & \\
105.1 & 94 & 0 & 6 & 0 & \\
140.9 & 88 & 0 & 12 & 0 & Sepiolite \\
169.8 & 83 & 11 & 6 & 0 & \\
200.6 & 78 & 11 & 11 & 0 & \\
224.8 & 83 & 14 & 3 & 0 & \\
\hline
\end{tabular}


Table 8. X-ray analyses of samples from Hole 630B.

\begin{tabular}{ccccc}
\hline $\begin{array}{c}\text { Sub-bottom } \\
\text { depth } \\
(\mathrm{m})\end{array}$ & $\begin{array}{c}\text { Calcite } \\
(\%)\end{array}$ & $\begin{array}{c}\text { Aragonite } \\
(\%)\end{array}$ & $\begin{array}{c}\text { Dolomite } \\
(\%)\end{array}$ & $\begin{array}{c}\text { Quartz } \\
(\%)\end{array}$ \\
\hline 3.04 & 64 & 36 & 0 & 0 \\
3.34 & 47 & 51 & 2 & 0 \\
\hline
\end{tabular}

\section{Possible Tie with Site 628}

Because Site 630 was located on LBB-10, possible correlations downslope with Site 628 involve tying LBB-10 to LBB-18 along LBB-05 (Fig. 1, this chapter). In an attempt to do this, the $A / B$ and $B / C$ sequence boundaries were first carried on LBB-18 from Site 628 approximately $9 \mathrm{~km}$ upslope to LBB-05 (Fig. 23). Only the B/C boundary, correlated with a late middle-early late Miocene hiatus in Hole $628 \mathrm{~A}$, could be carried for the entire distance. At the LBB-05/LBB-18 intersection, the $\mathrm{B} / \mathrm{C}$ boundary occurs at $0.305-0.325 \mathrm{~s}$, suggesting a depth range of 267-284 m sub-bottom, again according to a conversion velocity of $1.75 \mathrm{k} / \mathrm{s}$.

Along LBB-0 5 between LBB-18 and LBB-10, the B/C boundary exhibits as much as $0.06 \mathrm{~s}$ of relief (Fig. 22). At Site 630, the $\mathrm{B} / \mathrm{C}$ boundary occurs at a depth of $0.315 \mathrm{~s}$, or $276 \mathrm{~m}$ sub-bottom. This is approximately $26 \mathrm{~m}$ below the total depth drilled in Hole $630 \mathrm{~A}$, which translates to approximately $1 \mathrm{~m} . \mathrm{y}$. of section using the $27-28 \mathrm{~m} / \mathrm{m}$.y. sedimentation rate derived for the lower part of Hole 630A (see "Sediment-Accumulation Rate" section, this chapter). Core 630A-26X, the deepest core of Hole $630 \mathrm{~A}$, is dated as earliest late to late Miocene, which is consistent with the late middle-early late Miocene age postulated for the $\mathrm{B} / \mathrm{C}$ boundary at Site 628 . Although the B/C sequence boundary was not actually sampled at Site 630, a tie between Sites 628 and 630 using the $\mathrm{B} / \mathrm{C}$ boundary as a marker seems reasonable at this time.

\section{SUMMARY AND CONCLUSIONS}

Site 630 is at the upslope end of the three-site slope transect north of Little Bahama Bank. Hole $630 \mathrm{~A}$ penetrated $250 \mathrm{~m}$ of sediment with HPC/XCB coring. Hole $630 \mathrm{~B}$ duplicated the top $80 \mathrm{~m}$ of Hole $630 \mathrm{~A}$ with the HPC. Finally, Hole $630 \mathrm{C}$ recovered a mud-line core.

The stratigraphic section at Site 630 consists of the following units ("Sedimentology" and "Biostratigraphy" sections, this chapter, and Fig. 24): (1) periplatform ooze (nannofossil-foraminifer ooze plus bank-derived aragonite) with some chalk, steplike decrease of aragonite from $40 \%$ to $50 \%$ at the top to below XRD detection limits near $100 \mathrm{~m}$, late Miocene to Holocene, $146 \mathrm{~m}$; and (2) periplatform ooze and chalk with $40 \%$ turbidites of mainly bank-derived skeletal material, late Miocene, $104 \mathrm{~m}$.
Unlike Sites 627 and 628 , which are on the rise at the foot of the Little Bahama Bank platform, Site 630 lies on the slope (s.s.) at an angle of $2^{\circ}$ to $3^{\circ}$. Present-day slope topography shows widely spaced gullies that are interpreted as being the erosional pathways of turbidity currents (Mullins et al., 1984). Quaternary sediment cover on this gullied slope consists mainly of periplatform ooze. The coarser debris shed by the platform bypasses the slope in turbidity currents, forming an apron of turbidites and debris sheets on the rise (Mullins et al., 1984). An undisturbed section of upper Miocene-Holocene periplatform ooze at Site 630 indicates that bypassing has persisted for the last 6 m.y. Before $6 \mathrm{Ma}$, the site formed part of the turbidite apron on the rise. This succession is consistent with the progradation of the platform flank inferred from the lithologic and seismic facies at Sites 627 and 628 (see Site 627 and 628 chapters, this volume).

Despite bypassing by sandy turbidity currents, sedimentation rates in the periplatform ooze are high, somewhere between 27 and $62 \mathrm{~m} / \mathrm{m}$.y. (see "Sediment-Accumulation Rate" section, this chapter). Rates in the underlying turbidite facies are not well constrained. Biostratigraphic studies indicate, however, that they are at least as high as in the overlying unit of periplatform ooze.

Superimposed on the changes of depositional facies is a diagenetic trend that converts periplatform ooze rich in bank-derived aragonite into chalk ("Inorganic Geochemistry" section, this chapter). Major factors in this process seem to be dissolution of aragonite and upward migration of calcium-rich pore waters from the Cretaceous.

The correlation of borehole and seismic stratigraphy is more ambiguous at Site 630 than at the preceding sites ("Physical Properties" and "Seismic Stratigraphy" sections, this chapter). A seismic unconformity on LBB-10 corresponds to an early Pleistocene hiatus probably between Cores $630 \mathrm{~A}-1 \mathrm{H}$ and $630 \mathrm{~A}-2 \mathrm{H}$. Another seismic unconformity at the top of an interval of highamplitude reflections at $0.28 \mathrm{~s}$ correlates either with a bundle of turbidites having a top at $203 \mathrm{~m}$ sub-bottom or with an increase in lithification, i.e., a diagenetic boundary, below $200 \mathrm{~m}$ subbottom that is represented by a zone of poor recovery in Hole $630 \mathrm{~A}$.

\section{REFERENCES}

Gieskes, J. M., 1981. Deep-sea drilling interstitial water studies: Implications for chemical alteration of the oceanic crust, Layers 1 and 2. SEPM Spec. Publ., 32:149-167.

Mullins, H. T., Heath, K. C., Van Buren, H. M., and Newton, C. R., 1984. Anatomy of a modern open-ocean carbonate slope: northern Little Bahama Bank. Sedimentology, 31:141-168.

Van Buren, H. M., and Mullins, H. T., 1983. Seismic stratigraphy and geologic development of an open-ocean carbonate slope: The northern margin of Little Bahama Bank. In Sheridan, R. E., Gradstein, F. M., et al., Init. Repts. DSDP, 76: Washington (U.S. Govt. Printing Office), 749-762.

Table 9. X-ray analyses of samples from Hole $630 \mathrm{C}$.

\begin{tabular}{|c|c|c|c|c|c|}
\hline $\begin{array}{l}\text { Sub-bottom } \\
\text { depth } \\
\text { (m) }\end{array}$ & $\begin{array}{c}\text { Calcite } \\
(\%)\end{array}$ & $\begin{array}{c}\text { Aragonite } \\
(\%)\end{array}$ & $\begin{array}{c}\text { Dolomite } \\
(\%)\end{array}$ & $\begin{array}{c}\text { Quartz } \\
(\%)\end{array}$ & Comments \\
\hline 1.45 & 23 & 75 & 3 & 0 & $\begin{array}{l}\text { Illite-montmorillonite present; } \\
\text { high-Mg calcite, } 16 \% \text {; } \\
\text { low-Mg calcite, } 7 \%\end{array}$ \\
\hline 2.95 & 56 & 44 & 0 & 0 & Illite-montmorillonite present \\
\hline 4.45 & 21 & 75 & 4 & 0 & $\begin{array}{l}\text { Illite-montmorillonite present; } \\
\text { high-Mg calcite, } 7 \% \text {; low- } \\
\mathrm{Mg} \text { calcite, } 14 \%\end{array}$ \\
\hline 5.95 & 66 & 34 & 0 & 0 & \\
\hline 7.45 & 58 & 42 & 0 & 0 & \\
\hline 8.95 & 42 & 57 & 1 & 0 & \\
\hline
\end{tabular}




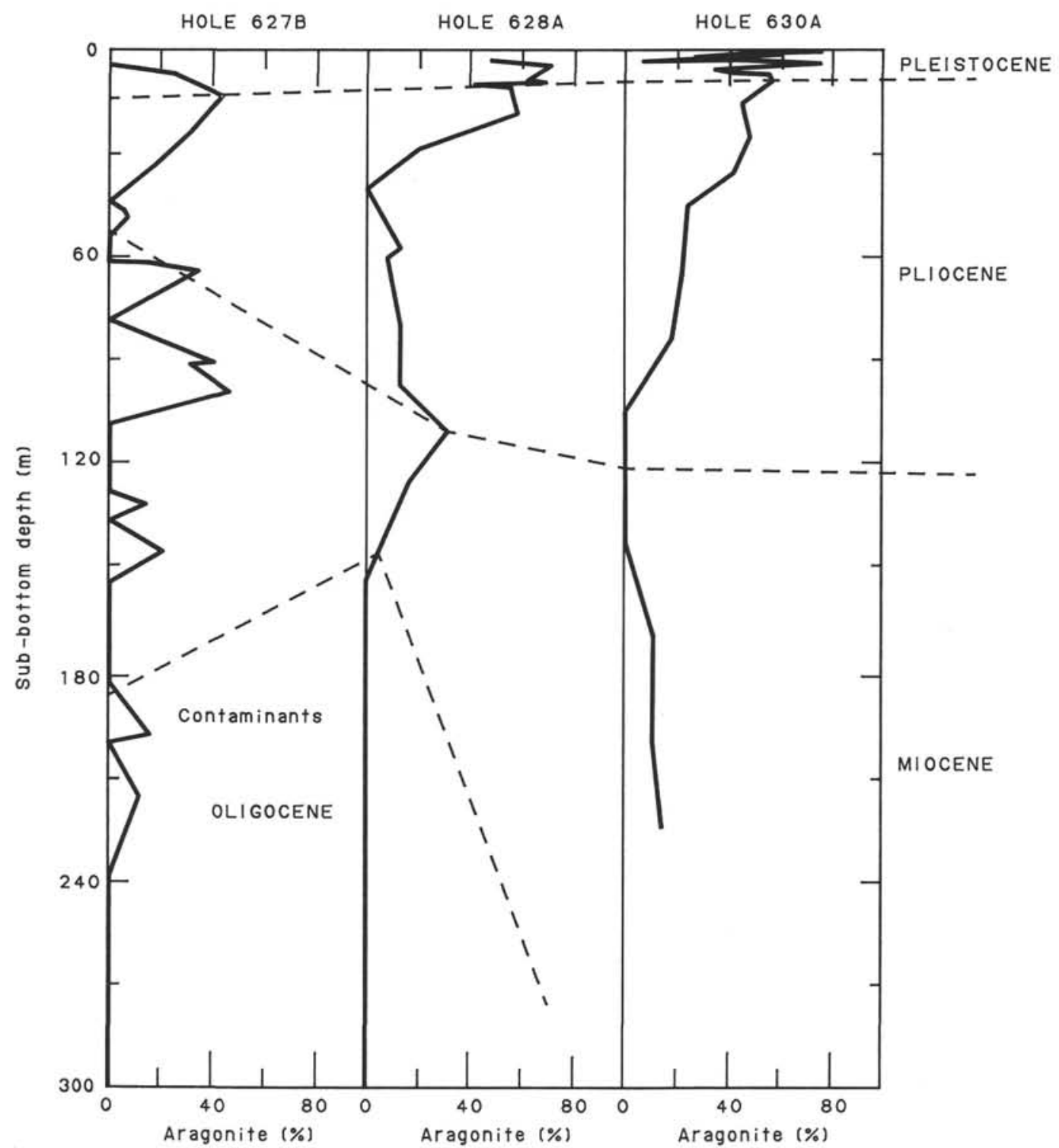

Figure 13. Summary of percentages of aragonite at Sites 627,628 , and 630 . Stratigraphic lines are based on ages reported in the "Biostratigraphy" section (this chapter). 


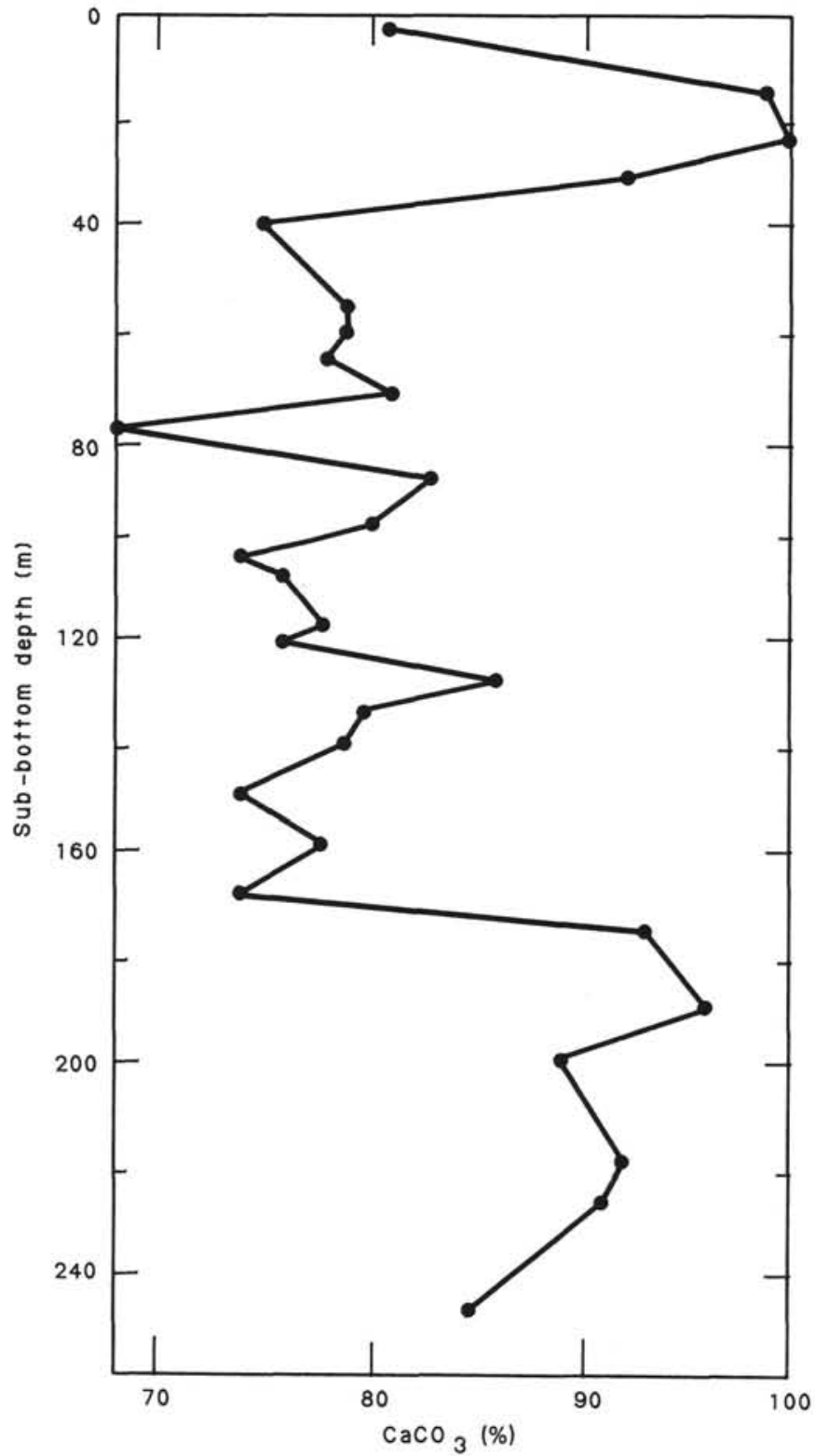

Figure 14. Carbonate-bomb data, Site 630.
Table 10. Carbonate-bomb data, Site 630.

\begin{tabular}{cr}
\hline $\begin{array}{c}\text { Sub-bottom depth } \\
(\mathrm{m})\end{array}$ & $\begin{array}{c}\mathrm{CaCO}_{3} \text { content } \\
(\%)\end{array}$ \\
\hline 2.2 & 81 \\
13.8 & 99 \\
23.4 & 100 \\
30.0 & 92 \\
39.6 & 75 \\
55.2 & 79 \\
59.1 & 79 \\
65.1 & 78 \\
71.5 & 81 \\
78.1 & 68 \\
87.9 & 83 \\
97.3 & 80 \\
100.3 & 77 \\
103.3 & 74 \\
106.9 & 76 \\
116.5 & 78 \\
119.5 & 76 \\
126.1 & 86 \\
132.1 & 80 \\
138.7 & 79 \\
148.3 & 74 \\
158.0 & 78 \\
167.6 & 74 \\
174.1 & 93 \\
188.8 & 96 \\
198.4 & 89 \\
217.7 & 92 \\
225.6 & 91 \\
246.1 & 85 \\
&
\end{tabular}




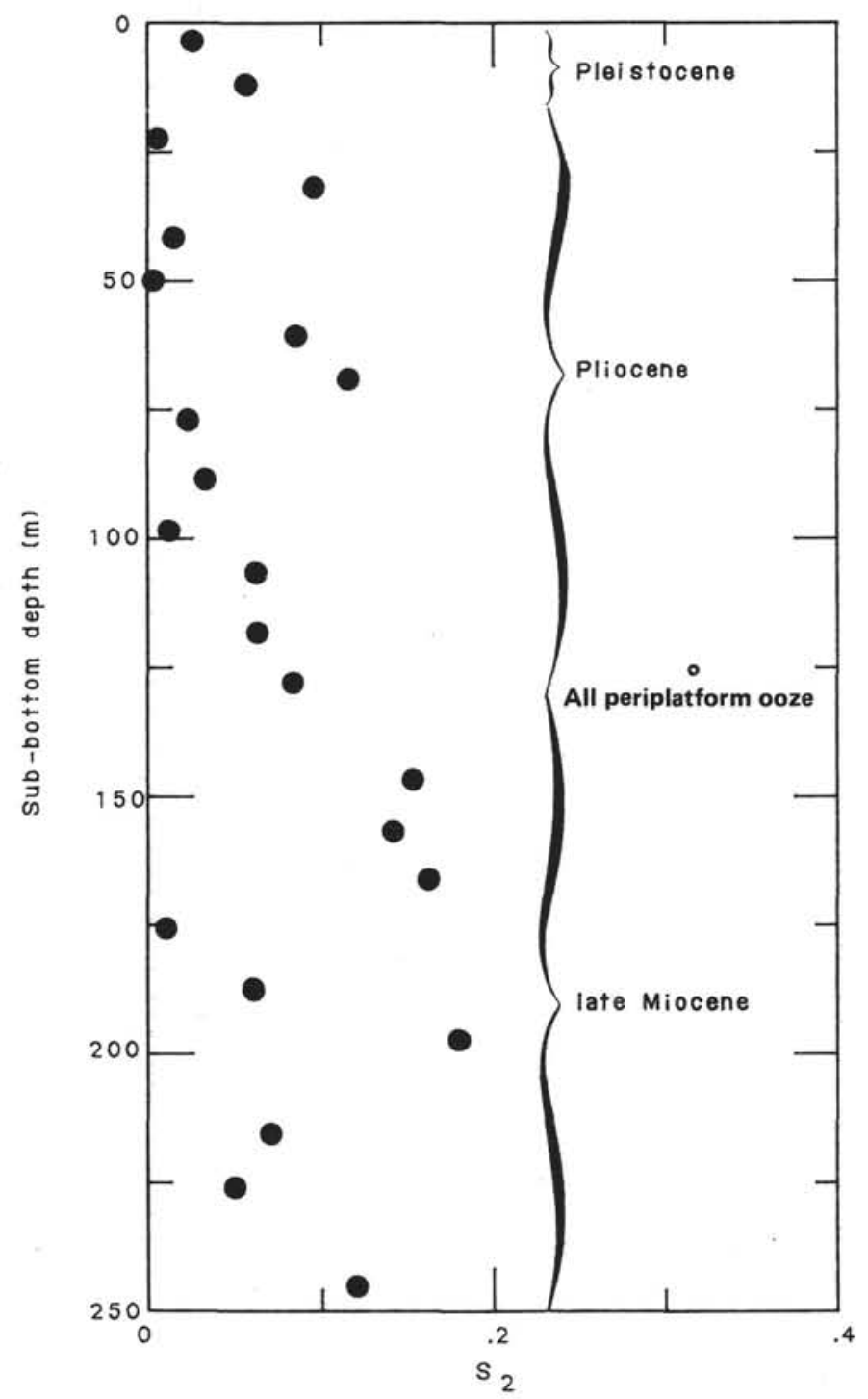

Figure 15. $\mathrm{S}_{2}$ downhole variation, Hole 630A.

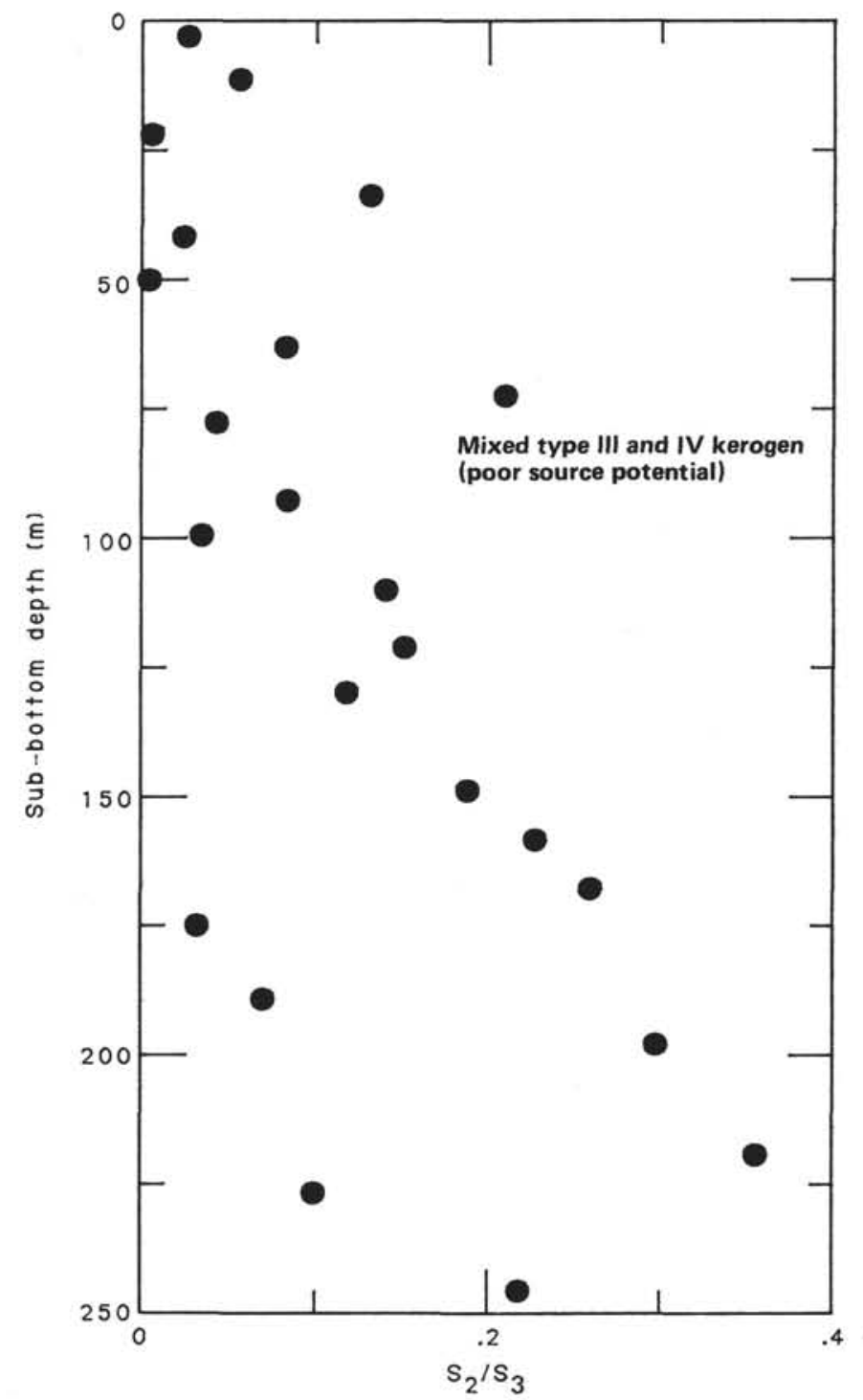

Figure 16. $S_{2} / S_{3}$ (kerogen typing) downhole, Hole 630A. 


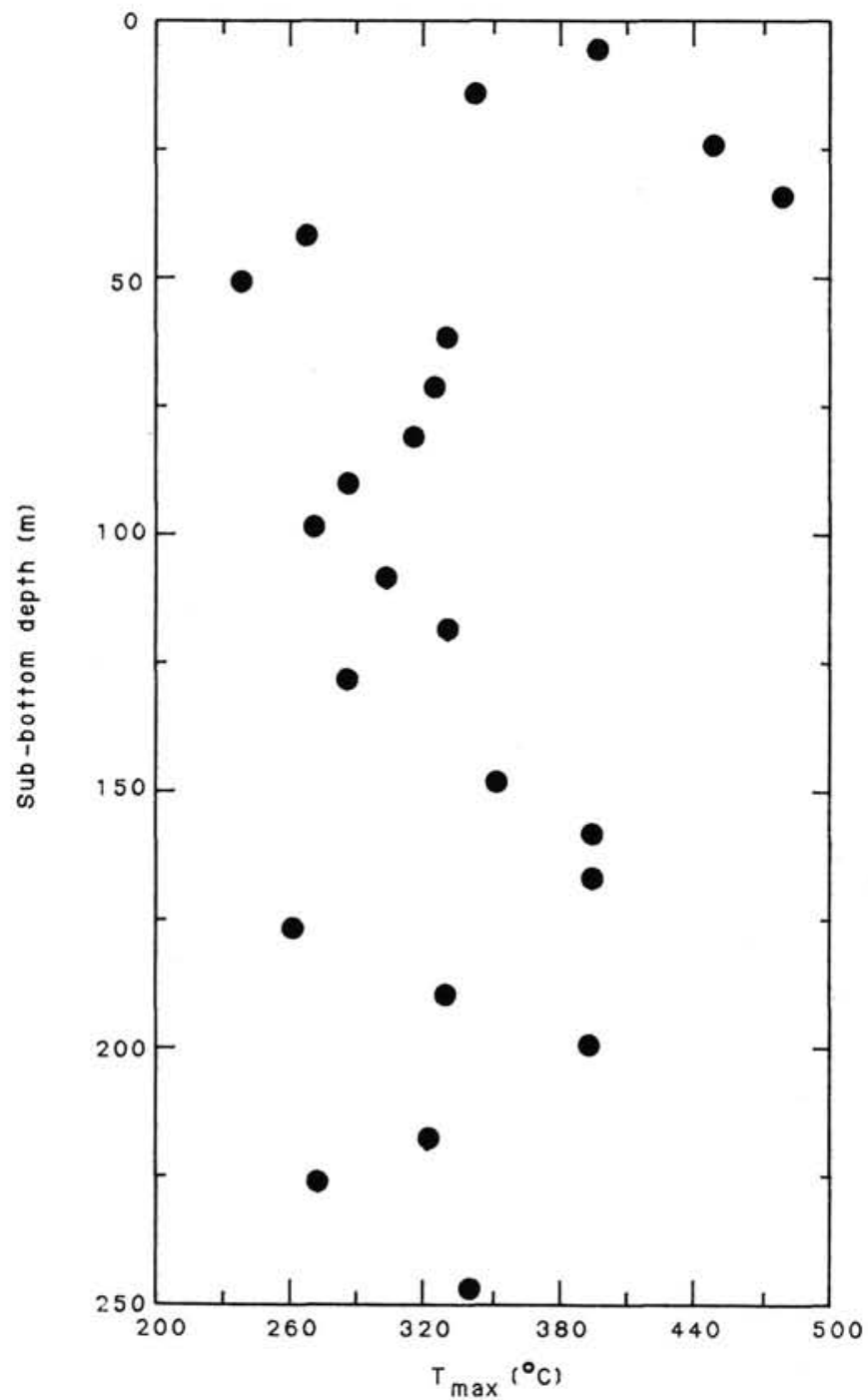

Figure 17. Downhole variation in $T_{\max }$, Hole 630A. Note random $T_{\max }$ values, indicating mixed detrital sources.

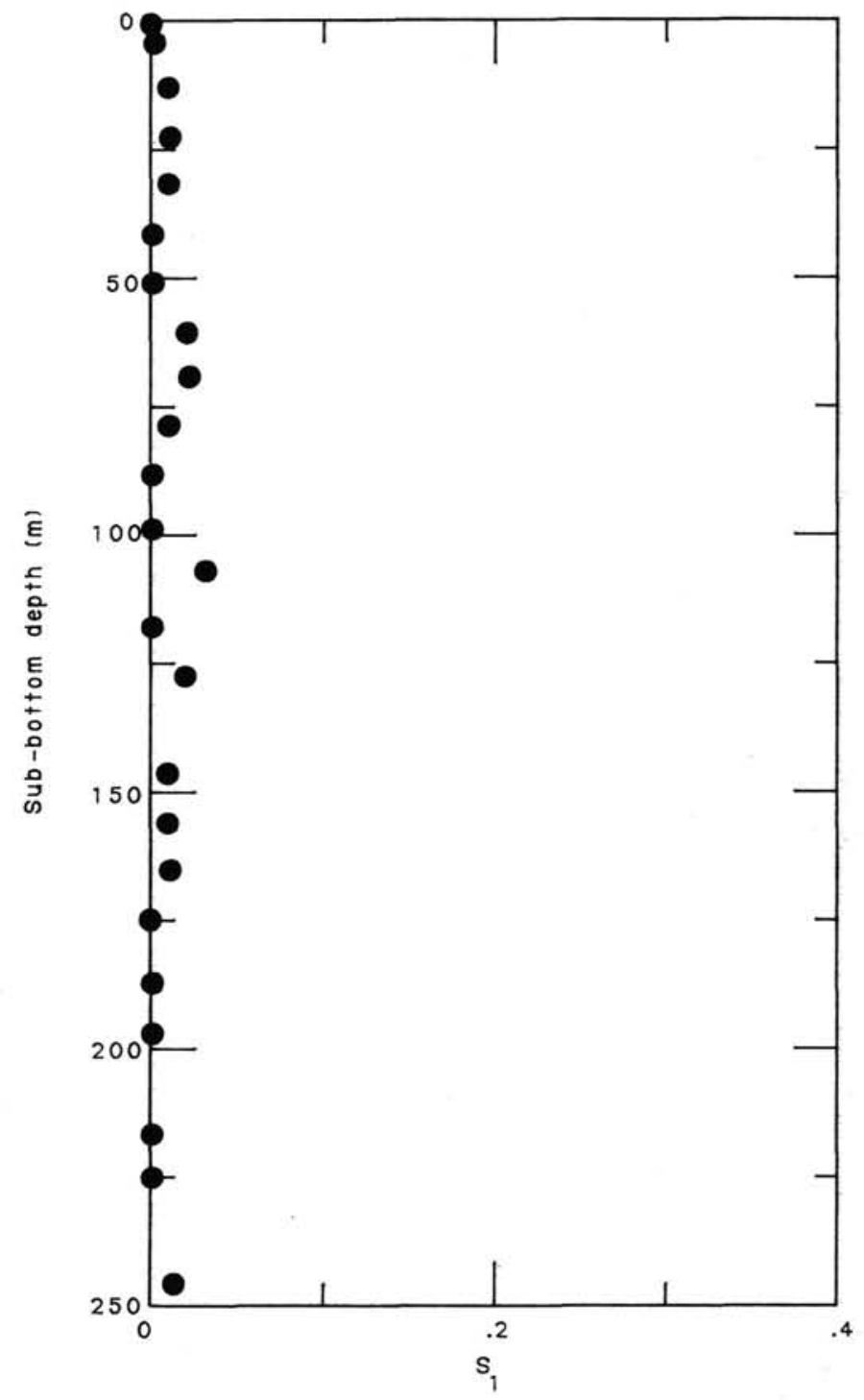

Figure $18 . \mathrm{S}_{1}$ content (bitumen) downhole, Hole 630A, showing negligible bitumen content. 


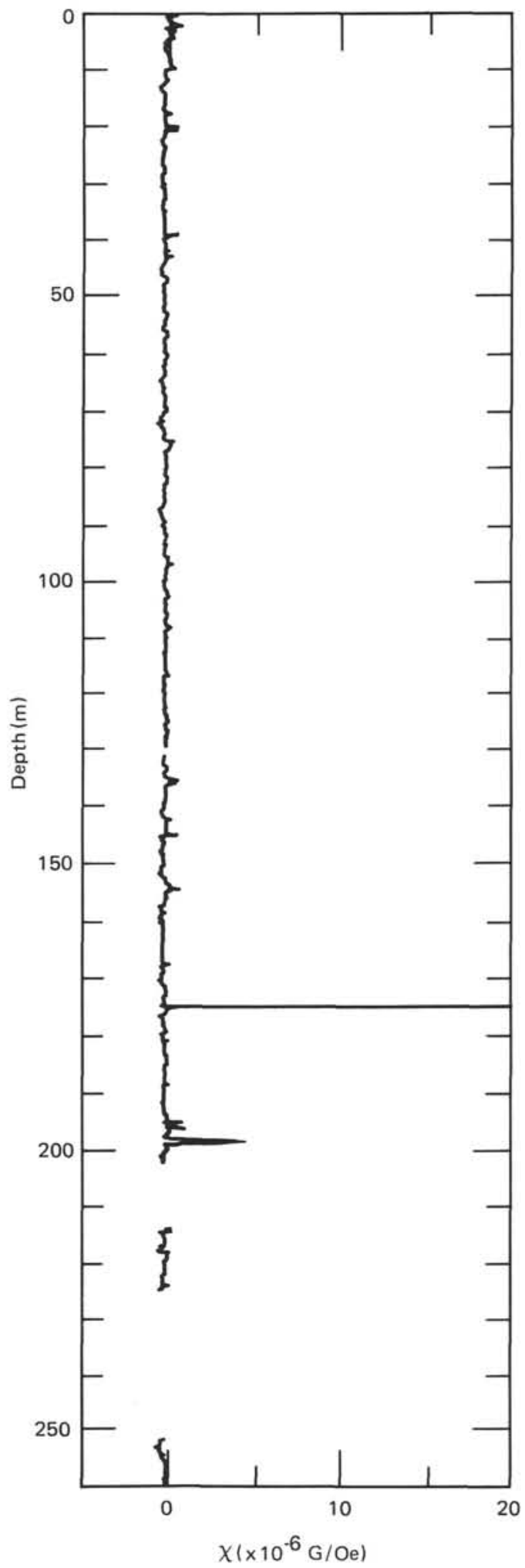

Figure 19. Magnetic-susceptibility values $\left(\times 10^{-6} \mathrm{G} / \mathrm{Oe}\right)$ plotted vs. sub-bottom depth in Hole 630A. Spikes related to rust contamination have been mostly eliminated by excluding Section 1 of each core from measurement. 


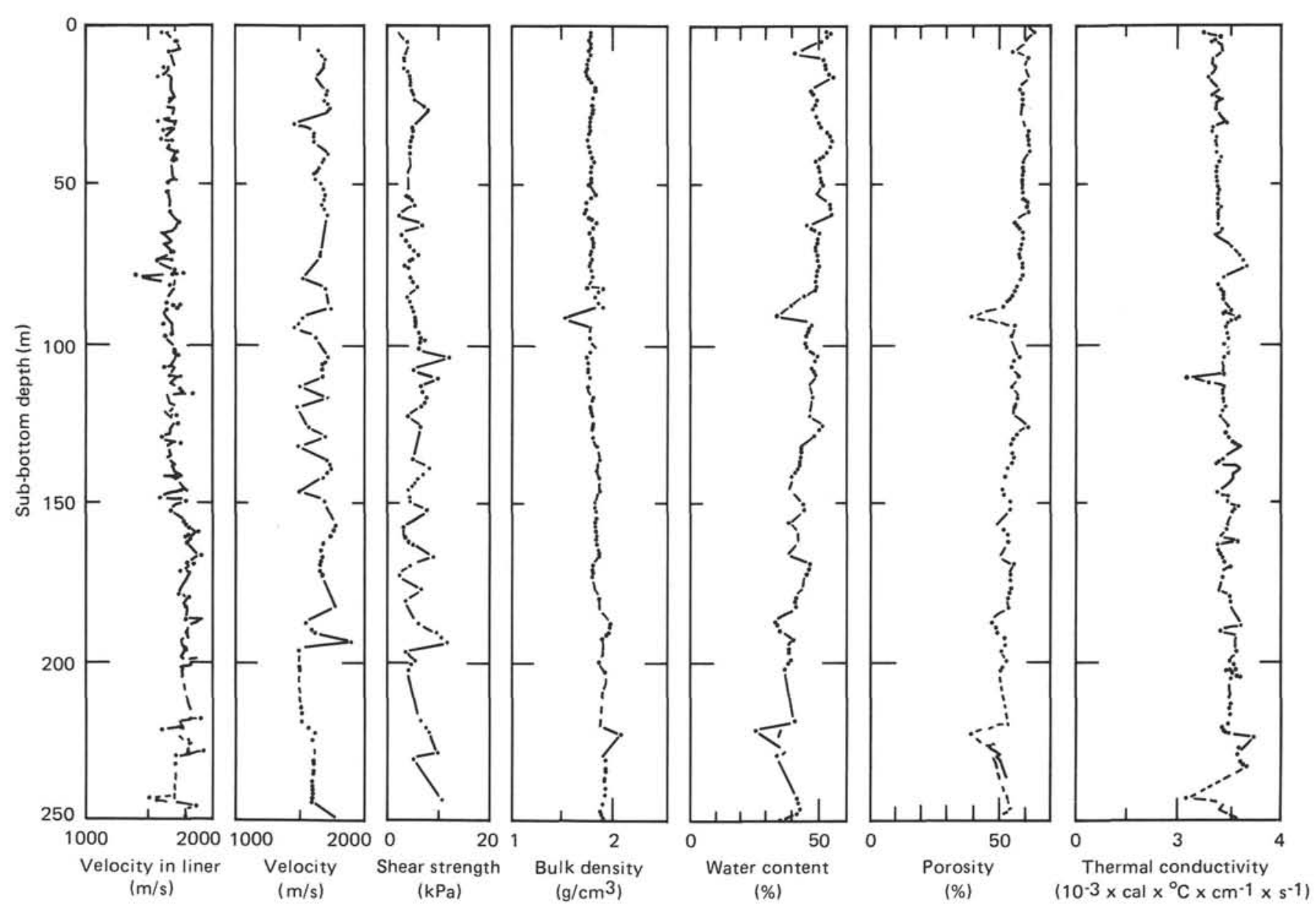

Figure 20. Graphic summary of the physical properties of Hole 630A. Density, water content, and porosity values were determined by gravimetric and volumetric techniques. 
Table 11. Physical properties of sediments, Site 630.

\begin{tabular}{|c|c|c|c|c|c|c|c|c|}
\hline $\begin{array}{c}\text { Sample } \\
\text { (level in cm) }\end{array}$ & $\begin{array}{l}\text { Sub-bottom } \\
\text { depth } \\
\text { (m) }\end{array}$ & $\begin{array}{l}\text { Velocity } \\
(\mathrm{m} / \mathrm{s})\end{array}$ & $\begin{array}{l}\text { Velocity } \\
\text { in liner } \\
(\mathrm{m} / \mathrm{s})\end{array}$ & $\begin{array}{l}\text { Wet-bulk } \\
\text { density } \\
\left(\mathrm{g} / \mathrm{cm}^{3}\right)\end{array}$ & $\begin{array}{l}\text { Dry water } \\
\text { content } \\
(\%)\end{array}$ & $\begin{array}{c}\text { Porosity } \\
(\%)\end{array}$ & $\begin{array}{c}\text { Thermal } \\
\text { conductivity } \\
\left(10^{-3} \times \mathrm{cal}^{-} \times{ }^{\circ} \mathrm{C}^{-1}\right. \\
\left.\times \mathrm{cm}^{-1} \times \mathrm{s}^{-1}\right)\end{array}$ & $\begin{array}{c}\text { Shear } \\
\text { strength } \\
(\mathrm{kPa})\end{array}$ \\
\hline $1-1,20$ & & & 1695 & & & & & \\
\hline $1-2,75$ & 2.2 & & & 1.76 & 54.87 & 62.62 & 2.511 & 1.93 \\
\hline $1-2,100$ & & & 1603 & & & & & \\
\hline $1-3,75$ & 3.7 & & & & & & 2.794 & \\
\hline $1-4,20$ & & & 1713 & & & & & \\
\hline $1-4,70$ & 5.2 & 1681 & 1696 & 1.76 & 50.48 & 59.10 & 2.647 & 3.62 \\
\hline $1-4,100$ & & & 1714 & & & & & \\
\hline $1-5,75$ & 6.7 & & & & & & 2.853 & \\
\hline $1-6,20$ & & & 1728 & & & & & \\
\hline $1-6,70$ & 8.2 & 1655 & 1659 & 1.89 & 40.98 & 54.78 & 2.853 & 9.40 \\
\hline $2-2,20$ & & & 1668 & & & & & \\
\hline $2-2,70$ & 10.3 & 1696 & & 1.78 & 51.77 & 60.91 & 2.655 & 2.94 \\
\hline $2-3,75$ & 11.8 & & & & & & 2.666 & \\
\hline $2-4,20$ & & & $\begin{array}{l}1691 \\
1614\end{array}$ & & & & & \\
\hline $2-4,70$ & 13.3 & 1669 & 1614 & 1.74 & 53.35 & 60.41 & & 3.51 \\
\hline $2-4,100$ & & & 1649 & & & & 2.703 & \\
\hline $2-5,75$ & 14.8 & & & & & & 2.682 & \\
\hline $2-6,20$ & & & 1611 & & & & & \\
\hline $\begin{array}{l}2-6,70 \\
2-6,100\end{array}$ & 16.3 & 1635 & $\begin{array}{l}1582 \\
1677\end{array}$ & 1.75 & 54.59 & 61.72 & 2.534 & 4.42 \\
\hline $3-2,70$ & 20.3 & 1722 & 1679 & 1.82 & 46.49 & 57.75 & & 4.76 \\
\hline $3-2,100$ & & & 1678 & & & & 2.751 & \\
\hline $3-3,75$ & 21.8 & & & & & & 2.682 & \\
\hline $3-4,20$ & & & 1687 & & & & & \\
\hline $3-4,70$ & 23.3 & 1697 & 1667 & 1.79 & 48.72 & 58.88 & 2.866 & 5.44 \\
\hline $3-4,100$ & & & 1679 & & & & & \\
\hline $3-5,75$ & 24.8 & & & & & & 2.692 & \\
\hline $3-6,20$ & & 1732 & $\begin{array}{l}1636 \\
1649\end{array}$ & 1.80 & & & & \\
\hline $\begin{array}{l}3-6,70 \\
3-6,100\end{array}$ & 26.3 & & 1687 & 1.80 & 48.28 & 58.55 & 2.686 & 7.70 \\
\hline $4-2,20$ & & & 1656 & & & & & \\
\hline $4-2,70$ & 30.3 & 1449 & 1579 & 1.76 & 50.08 & 58.81 & 2.888 & 4.76 \\
\hline $4-2,100$ & & & 1709 & & & & & \\
\hline $4-3,75$ & 31.8 & & & & & & 2.643 & \\
\hline $4-4,20$ & & & 1690 & & & & & \\
\hline $\begin{array}{l}4-4,70 \\
4-4,100\end{array}$ & 33.3 & 1622 & $\begin{array}{l}1623 \\
1668\end{array}$ & 1.76 & 53.23 & 61.01 & 2.669 & 4.87 \\
\hline $4-5,75$ & 34.8 & & & & & & 2.697 & \\
\hline $4-6,70$ & 36.3 & 1625 & 1595 & 1.74 & 54.5 & 61.32 & 2.693 & 4.30 \\
\hline $4-6,100$ & & & 1679 & & & & & \\
\hline $5-2,20$ & & & 1635 & & & & & \\
\hline $5-2,70$ & 39.7 & 1715 & 1724 & 1.77 & 52.82 & 61.30 & 2.704 & 4.08 \\
\hline $5-2,100$ & & & 1707 & & & & & \\
\hline $5-3,75$ & 41.2 & & 1714 & & & & 2.795 & \\
\hline $5-4,20$ & 42.7 & 1680 & 1668 & 1.80 & 48.98 & 59.05 & 2.783 & \\
\hline $\begin{array}{l}4-4,70 \\
5-4,100\end{array}$ & & & 1682 & & & & & 3.96 \\
\hline $5-5,75$ & 44.2 & & & & & & 2.704 & \\
\hline $5-6,20$ & & & 1670 & & & & & \\
\hline $5-6,70$ & 45.7 & 1619 & 1678 & 1.77 & 49.98 & 58.94 & 2.688 & 3.85 \\
\hline $5-6,100$ & & & 1678 & & & & & \\
\hline $6-2,20$ & & & 1712 & & & & & \\
\hline $6-2,70$ & 49.7 & 1667 & 1636 & 1.77 & 50.92 & 59.63 & & 3.17 \\
\hline $\begin{array}{l}6-2,100 \\
6-3,75\end{array}$ & 51.2 & & 1664 & & & & 2.759 & \\
\hline $6-4,20$ & & & 1656 & & & & & \\
\hline $\begin{array}{l}6-4,70 \\
6-4,100\end{array}$ & 52.7 & 1703 & $\begin{array}{l}1635 \\
1635\end{array}$ & 1.82 & 48.56 & 59.27 & 2.762 & 3.62 \\
\hline $\begin{array}{l}6-4,100 \\
6-5,75\end{array}$ & 54.2 & & 1635 & & & & 2.763 & \\
\hline $6-6,20$ & & & 1654 & & & & & \\
\hline $6-6,70$ & 55.7 & 1675 & & 1.75 & 53.7 & 61.13 & 2.756 & 5.44 \\
\hline $6-6,100$ & & & 1666 & & & & & \\
\hline $6-7,15$ & 56.6 & & & & & & 2.794 & \\
\hline $7-2,20$ & & & 1647 & & & & & \\
\hline $7-2,70$ & 59.1 & 1714 & 1681 & 1.72 & 55.13 & 61.36 & 2.751 & 1.93 \\
\hline $7-2,100$ & & & 1666 & & & & & \\
\hline $7-3,75$ & 60.6 & & 1736 & & & & 2.759 & \\
\hline $7-4,20$ & & & 1746 & 1.82 & 45.07 & 56.34 & 2.78 & \\
\hline $7-4,70$ & 62.1 & & 1721 & & & & & 6.68 \\
\hline $\begin{array}{l}7-4,100 \\
7-5,75\end{array}$ & 63.6 & & & & & & 2.806 & \\
\hline $7-6,20$ & & & 1676 & & & & & \\
\hline $7-6,70$ & 65.1 & & 1588 & 1.77 & 49.63 & 58.72 & 2.693 & 2.6 \\
\hline $7-6,100$ & & & 1600 & & & & & \\
\hline $8-2,20$ & & & 1669 & & & & & \\
\hline $8-2,70$ & 68.6 & 1672 & 1646 & 1.79 & 49.37 & 59.27 & 2.994 & 4.19 \\
\hline $8-2,100$ & & & 1626 & & & & & \\
\hline $8-3,75$ & 70.1 & & & & & & 3.141 & \\
\hline $8-4,20$ & & & 1701 & & & & & \\
\hline $8-4,70$ & 71.6 & 1655 & 1667 & 1.77 & 48.81 & 58.14 & 3.189 & 5.66 \\
\hline $8-4,100$ & & & 1681 & & & & & \\
\hline $8-5,75$ & 73.1 & & & & & & 3.286 & \\
\hline
\end{tabular}


Table 11 (continued).

\begin{tabular}{|c|c|c|c|c|c|c|c|c|}
\hline $\begin{array}{c}\text { Sample } \\
\text { (level in } \mathrm{cm} \text { ) }\end{array}$ & $\begin{array}{l}\text { Sub-bottom } \\
\text { depth } \\
\text { (m) }\end{array}$ & $\begin{array}{l}\text { Velocity } \\
(\mathrm{m} / \mathrm{s})\end{array}$ & $\begin{array}{c}\text { Velocity } \\
\text { in liner } \\
(\mathrm{m} / \mathrm{s})\end{array}$ & $\begin{array}{l}\text { Wet-bulk } \\
\text { density } \\
\left(\mathrm{g} / \mathrm{cm}^{3}\right)\end{array}$ & $\begin{array}{c}\text { Dry water } \\
\text { content } \\
(\%)\end{array}$ & $\begin{array}{c}\text { Porosity } \\
(\%)\end{array}$ & $\begin{array}{l}\text { Thermal } \\
\text { conductivity } \\
\left(10^{-3} \times \mathrm{cal}^{\circ} \times{ }^{\circ} \mathrm{C}^{-1}\right. \\
\left.\times \mathrm{cm}^{-1} \times \mathrm{s}^{-1}\right)\end{array}$ & $\begin{array}{c}\text { Shear } \\
\text { strength } \\
(\mathrm{kPa})\end{array}$ \\
\hline $8-6,20$ & & & 1636 & & & & & \\
\hline $8-6,70$ & 74.6 & & 1673 & 1.77 & 50.20 & 59.08 & 3.318 & 3.17 \\
\hline $8-6,100$ & & & 1562 & & & & & \\
\hline $9-2,20$ & & & 1752 & & & & & \\
\hline $9-2,70$ & 78.5 & 1508 & 1673 & 1.79 & 49.02 & 58.84 & 2.861 & 4.30 \\
\hline $9-3,75$ & 80.0 & & & & & & 2.749 & \\
\hline $9-4,20$ & & & 1700 & & & & & \\
\hline $9-4,70$ & 81.5 & 1700 & 1644 & 1.74 & 49.41 & 57.62 & 2.803 & 5.89 \\
\hline $9-4,100$ & & & 1655 & & & & & \\
\hline $9-5,75$ & 83.0 & & & & & & 2.882 & \\
\hline $9-6,20$ & & & 1697 & & & & & \\
\hline $8-6,70$ & 84.5 & & 1683 & 1.82 & 43.91 & 55.37 & 2.865 & \\
\hline $9-6,100$ & & & 1717 & & & & & 3.62 \\
\hline $10-2,20$ & & & 1641 & & & & & \\
\hline $10-2,70$ & 87.9 & & 1736 & 1.90 & 38.37 & 52.37 & 3.003 & 4.76 \\
\hline $10-2,100$ & & & 1642 & & & & & \\
\hline $10-3,75$ & 89.4 & & & & & & 2.867 & \\
\hline $10-4,20$ & & & 1612 & & & & & \\
\hline $10-4,70$ & 90.9 & 1516 & 1491 & 1.51 & 35.37 & 39.17 & 3.091 & 4.98 \\
\hline $10-5,75$ & 92.4 & & & & & & 2.949 & \\
\hline $10-6,20$ & & & 1645 & & & & & \\
\hline $10-6,70$ & 93.9 & 1452 & 1609 & 1.76 & 46.48 & 55.74 & 2.919 & 5.10 \\
\hline $10-6,100$ & & & 1679 & & & & & \\
\hline $11-2,20$ & & & 1670 & & & & & \\
\hline $11-2,70$ & 97.1 & 1623 & 1659 & 1.78 & 45.23 & 55.26 & 2.941 & 6.23 \\
\hline $11-2,100$ & & & 1620 & & & & & \\
\hline $\begin{array}{l}11-3,75 \\
11-4,20\end{array}$ & 98.6 & & 1645 & & & & 2.856 & \\
\hline $11-4,70$ & 100.1 & 1612 & 1681 & 1.81 & 44.81 & 55.95 & 2.970 & 5.66 \\
\hline $11-5,75$ & 101.6 & & & & & & 2.946 & \\
\hline $11-6,20$ & & & 1703 & & & & & \\
\hline $11-6,70$ & 103.1 & 1723 & 1723 & 1.74 & 48.8 & 57.03 & 2.875 & 11.78 \\
\hline $11-6,100$ & & & 1715 & & & & & \\
\hline $12-2,20$ & & & 1676 & & & & & \\
\hline $12-2,70$ & 106.8 & 1676 & 1626 & 1.75 & 46.62 & 55.41 & 2.870 & 4.76 \\
\hline $12-2,100$ & & & 1699 & & & & & \\
\hline $12-3,75$ & 108.3 & & & & & & 2.829 & \\
\hline $12-4,20$ & & & 1654 & & & & & \\
\hline $\begin{array}{l}12-4,70 \\
12-4,100\end{array}$ & 109.8 & 1679 & $\begin{array}{l}1729 \\
1663\end{array}$ & 1.78 & 48.68 & 58.25 & 2.117 & 9.17 \\
\hline $12-5,75$ & 111.3 & & & & & & 2.581 & \\
\hline $12-6,20$ & & & 1653 & & & & & \\
\hline $12-6,70$ & 112.8 & 1486 & 1675 & 1.74 & 46.01 & 54.6 & 2.842 & 6.34 \\
\hline $12-6,100$ & & & 1690 & & & & & \\
\hline $13-2,20$ & & & 1833 & & & & & \\
\hline $13-2,70$ & 116.1 & 1709 & 1643 & 1.8 & 46.44 & 56.96 & 2.843 & 7.53 \\
\hline $13-2,100$ & & & 1643 & & & & & \\
\hline $13-3,75$ & 117.6 & & & & & & 2.842 & \\
\hline $\begin{array}{l}13-4,20 \\
13-4,70\end{array}$ & 119.1 & 1466 & $\begin{array}{l}1659 \\
1661\end{array}$ & 1.78 & 46.5 & 56.27 & 2.907 & 6.53 \\
\hline $13-4,100$ & & & 1701 & 1.70 & . & & & \\
\hline $13-5,75$ & 120.6 & & & & & & 2.859 & \\
\hline $13-6,20$ & & & 1659 & & & & & \\
\hline $13-6,70$ & 122.1 & & 1606 & 1.79 & 45.99 & 56.4 & 2.816 & 3.77 \\
\hline $13-6,100$ & & & 1719 & & & & & \\
\hline $14-2,20$ & & & 1709 & & & & & \\
\hline $14-2,70$ & 125.7 & 1571 & 1673 & 1.8 & 51.6 & 61.25 & 2.934 & 6.28 \\
\hline $14-2,100$ & & & 1638 & & & & & \\
\hline $14-3,75$ & 127.2 & & & & & & 2.895 & \\
\hline $14-4,20$ & & & 1645 & & & & & \\
\hline $14-4,70$ & 128.7 & 1704 & 1657 & 1.79 & 47.58 & 57.55 & 2.938 & 32.32 \\
\hline $14-4,100$ & & & 1597 & & & & & \\
\hline $14-5,75$ & 130.2 & & & & & & 3.065 & \\
\hline $14-6,20$ & & & $\begin{array}{l}1739 \\
1644\end{array}$ & & & & & \\
\hline $\begin{array}{l}14-6,70 \\
14-6,100\end{array}$ & 131.7 & 1476 & $\begin{array}{l}1644 \\
1637\end{array}$ & 1.84 & 43.05 & 55.08 & 3.210 & \\
\hline $15-2,20$ & & & 1662 & & & & & \\
\hline $15-2,70$ & 135.6 & & 1828 & 1.86 & 43.15 & 55.95 & 2.850 & 4.77 \\
\hline $15-2,100$ & & 1687 & 1630 & & & & & \\
\hline $15-3,75$ & 137.1 & & & & & & 2.763 & \\
\hline $15-4,20$ & 138.6 & & 1700 & & & & & \\
\hline $15-4,70$ & & 1729 & 1678 & 1.84 & 42.06 & 54.25 & $\begin{array}{l}3.177 \\
3.053\end{array}$ & 7.79 \\
\hline $\begin{array}{l}15-5,75 \\
15-6,20\end{array}$ & 140.1 & & 1738 & & & & 3.053 & \\
\hline $15-6,70$ & 141.6 & 1678 & 1606 & 1.87 & 39.73 & 52.99 & 3.032 & 5.78 \\
\hline $15-6,100$ & & & 1723 & & & & & \\
\hline $16-2,20$ & & & 1759 & & & & & \\
\hline $\begin{array}{l}16-2,70 \\
16-2,100\end{array}$ & 145.4 & 1504 & $\begin{array}{l}1735 \\
1791\end{array}$ & 1.86 & 39.16 & 52.17 & 2.773 & 3.77 \\
\hline $\begin{array}{l}16-2,100 \\
16-3,75\end{array}$ & 146.9 & & 1791 & & & & 2.980 & \\
\hline $16-4,20$ & & & 1575 & & & & & \\
\hline $16-4,70$ & 148.4 & 1706 & 1768 & 1.82 & 43.42 & 54.93 & 2.958 & 4.02 \\
\hline
\end{tabular}


Table 11 (continued).

\begin{tabular}{|c|c|c|c|c|c|c|c|c|}
\hline $\begin{array}{c}\text { Sample } \\
\text { (level in } \mathrm{cm} \text { ) }\end{array}$ & $\begin{array}{l}\text { Sub-bottom } \\
\text { depth } \\
\text { (m) }\end{array}$ & $\begin{array}{l}\text { Velocity } \\
(\mathrm{m} / \mathrm{s})\end{array}$ & $\begin{array}{c}\text { Velocity } \\
\text { in liner } \\
(\mathrm{m} / \mathrm{s})\end{array}$ & $\begin{array}{l}\text { Wet-bulk } \\
\text { density } \\
\left(\mathrm{g} / \mathrm{cm}^{3}\right)\end{array}$ & $\begin{array}{l}\text { Dry water } \\
\text { content } \\
(\%)\end{array}$ & $\begin{array}{c}\text { Porosity } \\
(\%)\end{array}$ & $\begin{array}{c}\text { Thermal } \\
\text { conductivity } \\
\left(10^{-3} \times \mathrm{cal}^{\circ} \times{ }^{\circ} \mathrm{C}^{-1}\right. \\
\left.\times \mathrm{cm}^{-1} \times \mathrm{s}^{-1}\right)\end{array}$ & $\begin{array}{l}\text { Shear } \\
\text { strength } \\
(\mathrm{kPa})\end{array}$ \\
\hline $16-5,75$ & 149.9 & & & & & & 3.135 & \\
\hline $16-6,70$ & 151.4 & & 1683 & 1.82 & 43.63 & 55.24 & 3.046 & 7.53 \\
\hline $16-6,100$ & & & 1652 & & & & & \\
\hline $17-2,20$ & & & 1789 & & & & & \\
\hline $17-2,70$ & 156.0 & 1788 & 1799 & 1.83 & 38.00 & 50.04 & 2.888 & 2.76 \\
\hline $17-2,100$ & & & 1780 & & & & & \\
\hline $17-3,75$ & 156.6 & & & & & & 2.944 & \\
\hline $17-4,20$ & & & 1874 & & & & & \\
\hline $17-4,70$ & 158.0 & 1746 & 1833 & 1.85 & 41.59 & 54.29 & 2.811 & 3.01 \\
\hline $17-4,100$ & & & 1788 & & & & & \\
\hline $17-5,75$ & 159.5 & & & & & & 3.136 & \\
\hline $17-6,20$ & & & 1829 & & & & & \\
\hline $17-6,30$ & 160.5 & 1668 & & 1.84 & 41.93 & 54.26 & 2.756 & 4.78 \\
\hline $17-6,46$ & & & 1803 & & & & & \\
\hline $18-2,20$ & & & 1854 & & & & & \\
\hline $18-2,70$ & 164.6 & 1681 & 2005 & 1.87 & 38.14 & 51.37 & 2.867 & 8.79 \\
\hline $18-2,100$ & & & 1894 & & & & & \\
\hline $18-3,75$ & 166.1 & & & & & & 2.919 & \\
\hline $18-4,20$ & & & 1791 & & & & & \\
\hline $18-4,70$ & 167.6 & 1653 & 1834 & 1.79 & 46.02 & 56.31 & 3.014 & 4.27 \\
\hline $18-4,100$ & & & 1841 & & & & & \\
\hline $18-5,75$ & 169.1 & & & & & & 2.848 & \\
\hline $18-6,20$ & & & 1743 & & & & & \\
\hline $18-6,70$ & 170.6 & 1669 & 1820 & 1.79 & 45 & 55.53 & 2.871 & 2.51 \\
\hline $18-6,100$ & & & 1813 & & & & & \\
\hline $19-2,75$ & 174.1 & & & 1.83 & 43.8 & 55.50 & 2.803 & 6.53 \\
\hline $19-3,75$ & 175.6 & & & & & & 3.024 & \\
\hline $19-4,20$ & & & 1743 & & & & & \\
\hline $19-4,70$ & 177.1 & & 1796 & 1.87 & 40.66 & 53.74 & 2.994 & 3.01 \\
\hline $19-4,100$ & & & 1769 & & & & & \\
\hline $19-5,75$ & 179.6 & & & & & & 3.097 & \\
\hline $19-6,20$ & & & 1756 & & & & & \\
\hline $19-6,70$ & 181.1 & 1768 & 1797 & 1.86 & 41.21 & 53.95 & 3.214 & \\
\hline $19-6,100$ & & & 1774 & & & & & \\
\hline $20-2,20$ & & & 1873 & & & & & \\
\hline $20-2,70$ & 185.8 & 1548 & 1908 & 1.98 & 32.44 & 48.19 & 3.219 & 5.78 \\
\hline $20-2,100$ & & & 1781 & & & & & \\
\hline $20-3,75$ & 187.3 & & & & & & 2.798 & \\
\hline $20-4,20$ & & & 1804 & & & & & \\
\hline $20-4,70$ & 188.8 & 1604 & 1791 & 1.95 & 34.47 & 49.69 & 3.107 & 9.54 \\
\hline $20-5,75$ & 190.3 & & & & & & 3.108 & \\
\hline $20-6,20$ & & & 1805 & & & & & \\
\hline $20-6,70$ & 191.7 & 1894 & 1745 & 1.89 & 39.65 & 53.44 & 3.013 & 11.05 \\
\hline $21-2,20$ & & & 1775 & & & & & \\
\hline $21-2,70$ & 195.7 & 1500 & 1764 & 1.90 & 38.06 & 52.02 & 3.100 & 3.01 \\
\hline $21-2,100$ & & & 1778 & & & & & \\
\hline $21-3,75$ & 197.2 & & & & & & 2.998 & \\
\hline $21-4,20$ & & & 1732 & & & & & \\
\hline $21-4,70$ & 198.7 & 1495 & 1752 & 1.88 & 39.07 & 52.53 & 3.078 & 5.22 \\
\hline $21-4,100$ & & & 1856 & & & & & \\
\hline $21-5,75$ & 200.2 & & & & & & 2.911 & \\
\hline $21-6,20$ & & & 1809 & & & & & \\
\hline $21-6,70$ & 201.7 & 1505 & 1744 & 1.91 & 37.18 & 51.39 & 3.033 & 3.77 \\
\hline $21-6,100$ & & & 1749 & & & & & \\
\hline $22-1,50$ & 211.8 & & & & & & & \\
\hline $23-1,75$ & 213.3 & & & & & & 2.979 & \\
\hline $23-2,20$ & & & 1808 & 1.87 & 40.96 & 54.16 & & \\
\hline $23-2,70$ & 214.7 & 1512 & 1896 & & & & 2.848 & 6.53 \\
\hline $23-2,100$ & & & 1743 & & & & & \\
\hline $23-3,75$ & 216.3 & & & & & & 2.902 & \\
\hline $23-3,100$ & 218.8 & 1620 & & 2.06 & 24.49 & 40.10 & 3.464 & \\
\hline $24-1,75$ & 222.6 & & & & & & 3.162 & \\
\hline $24-2,20$ & & & 1793 & & & & & \\
\hline $24-2,70$ & 224.1 & & 1923 & 1.90 & 36.94 & 51.02 & 2.959 & 9.79 \\
\hline $24-2,100$ & & & 1803 & & & & & \\
\hline $24-3,20$ & & & 1809 & & & & & \\
\hline $24-3,70$ & 225.6 & & 1802 & 1.93 & 33.76 & 48.49 & 3.260 & 4.77 \\
\hline $24-3,100$ & & & 1685 & & & & & \\
\hline $24-4,20$ & 227.1 & & & & & & 3.305 & \\
\hline $25-1,15$ & 231.5 & & & & & & 2.147 & \\
\hline $26-2,20$ & & & 1706 & & & & & \\
\hline $26-2,70$ & 243.1 & 1596 & 1500 & 1.89 & 41.28 & 55.00 & 2.961 & 10.55 \\
\hline $26-2,100$ & & & 1707 & & & & & \\
\hline $26-3,75$ & 244.6 & & & & & & 2.792 & \\
\hline $26-4,20$ & & & 1867 & & & & & \\
\hline $26-4,70$ & 246.1 & & 1813 & 1.86 & 42.64 & 55.34 & 2.89 & \\
\hline $26-4,100$ & & & 1766 & & & & & \\
\hline $26-5,75$ & 247.6 & & & & & & 3.081 & \\
\hline $26-6,20$ & & & 1778 & & & & & \\
\hline $26-6,70$ & 249.1 & 1820 & 1487 & 1.92 & 34.29 & 48.83 & 3.136 & \\
\hline $26-6,100$ & & & 1970 & & & & & \\
\hline
\end{tabular}


Line LBB-10

Water depth $=1.11 \mathrm{~s}=832.5 \mathrm{~m}$

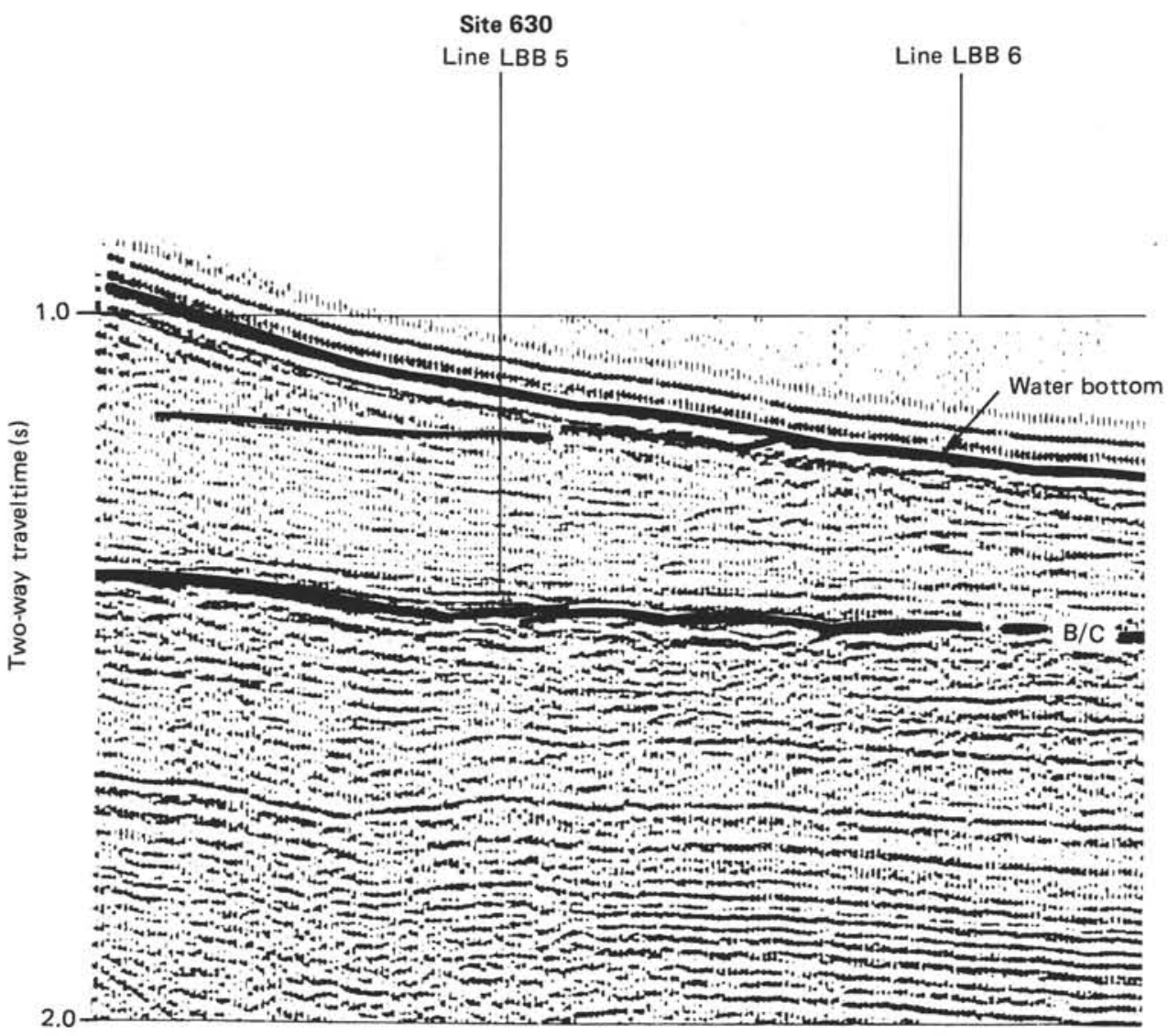

Figure 21. Part of line LBB-10, showing both sequence boundaries sampled at Site 630 (total depth of penetration is shown by a vertical line). The B/C sequence boundary lies slightly deeper than the postulated total depth of this site. 


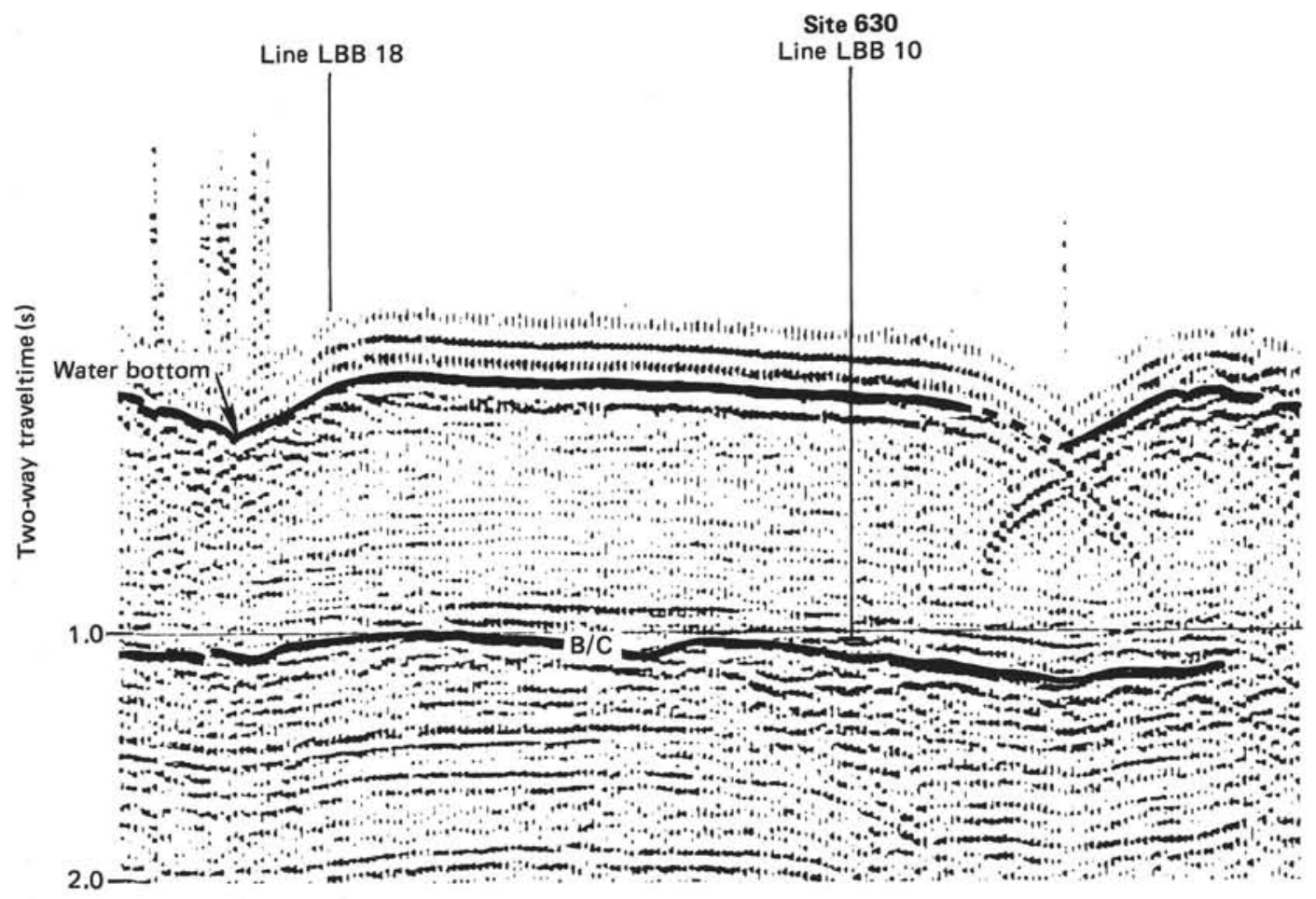

Figure 22. Part of line LBB-05, illustrating relief on the B/C sequence boundary between lines LBB-18 and LBB-10. Note that $\mathrm{B} / \mathrm{C}$ lies slightly deeper than the total depth at Site 630 .

Line LBB 18

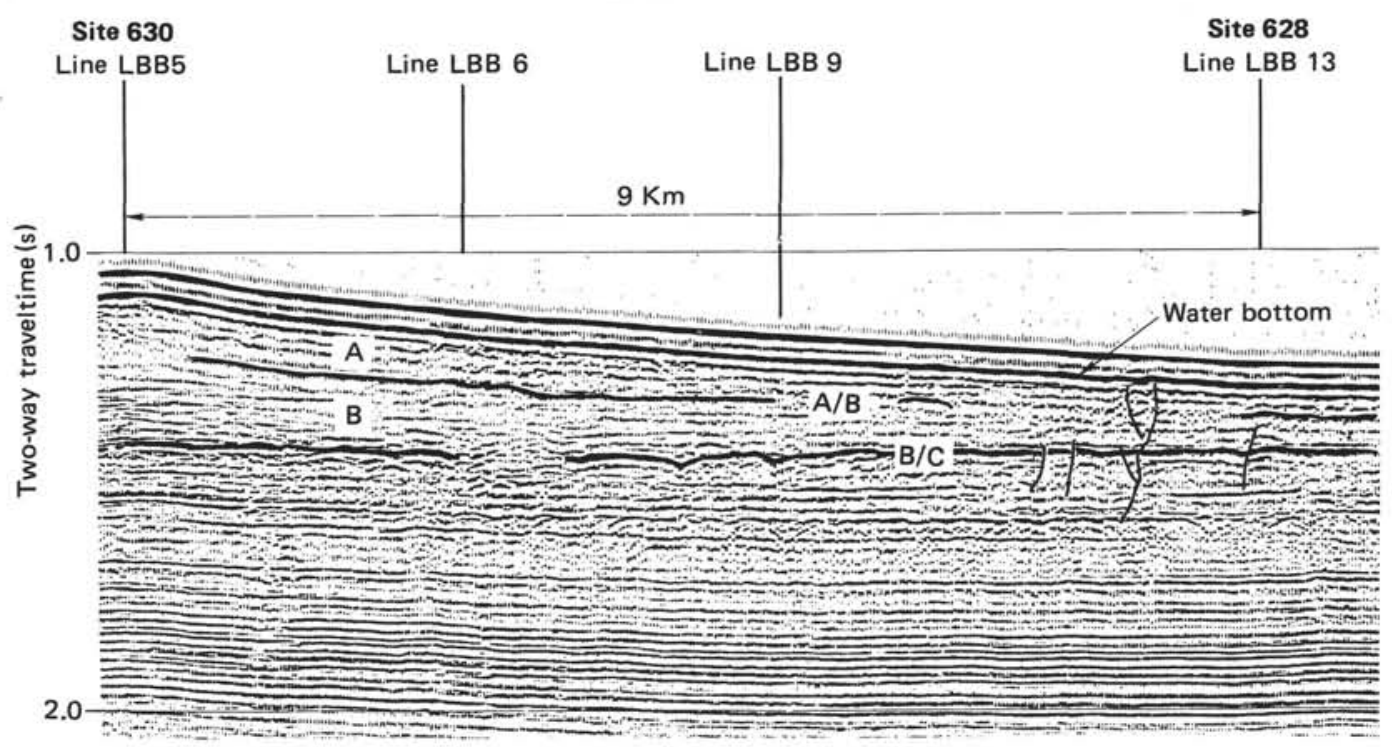

Figure 23. Part of line L.BB-18, showing the lateral expression of the $\mathrm{A} / \mathrm{B}$ and $\mathrm{B} / \mathrm{C}$ sequence boundaries between Site 628 and survey line LBB-05. Only the B/C boundary can be carried with confidence. 


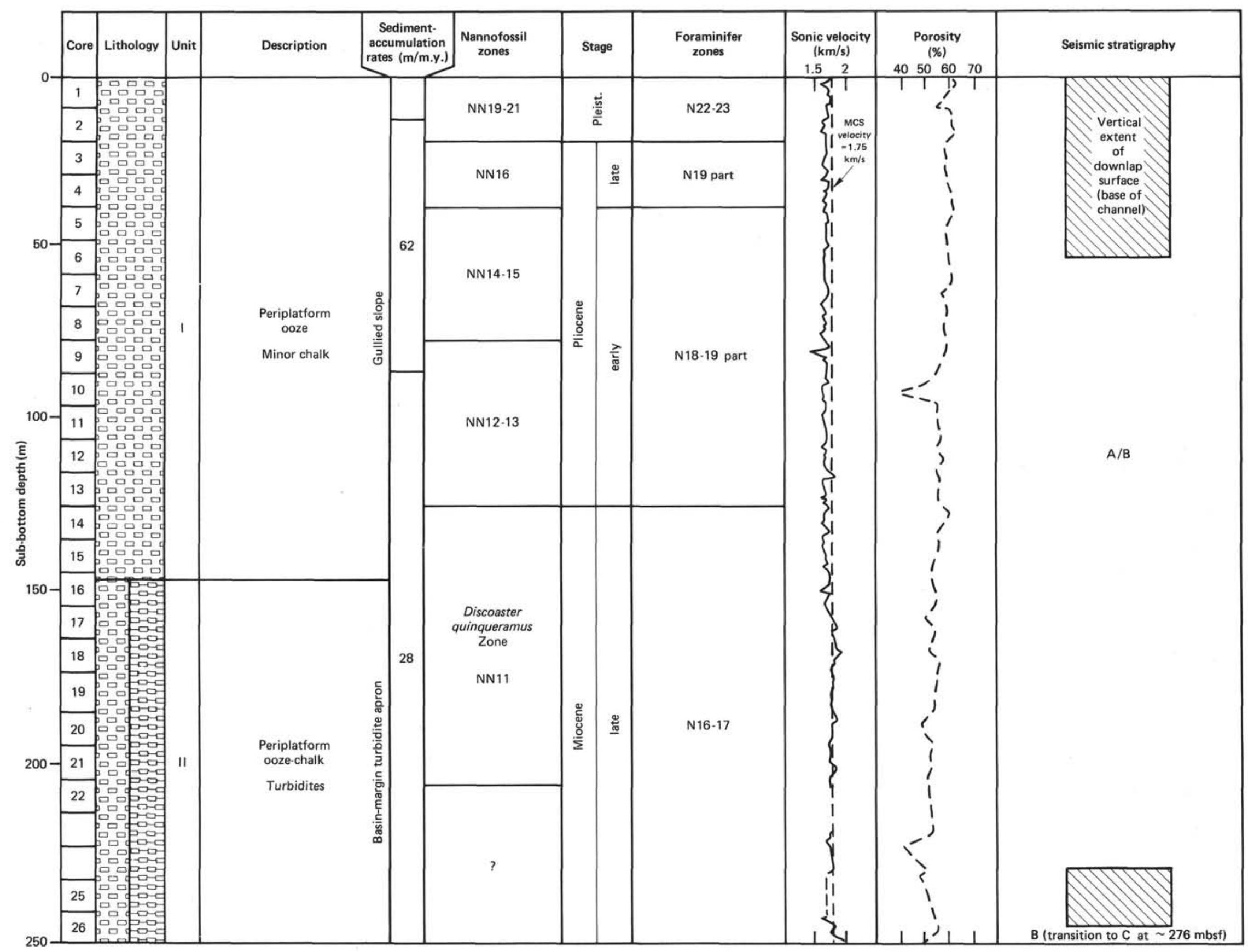



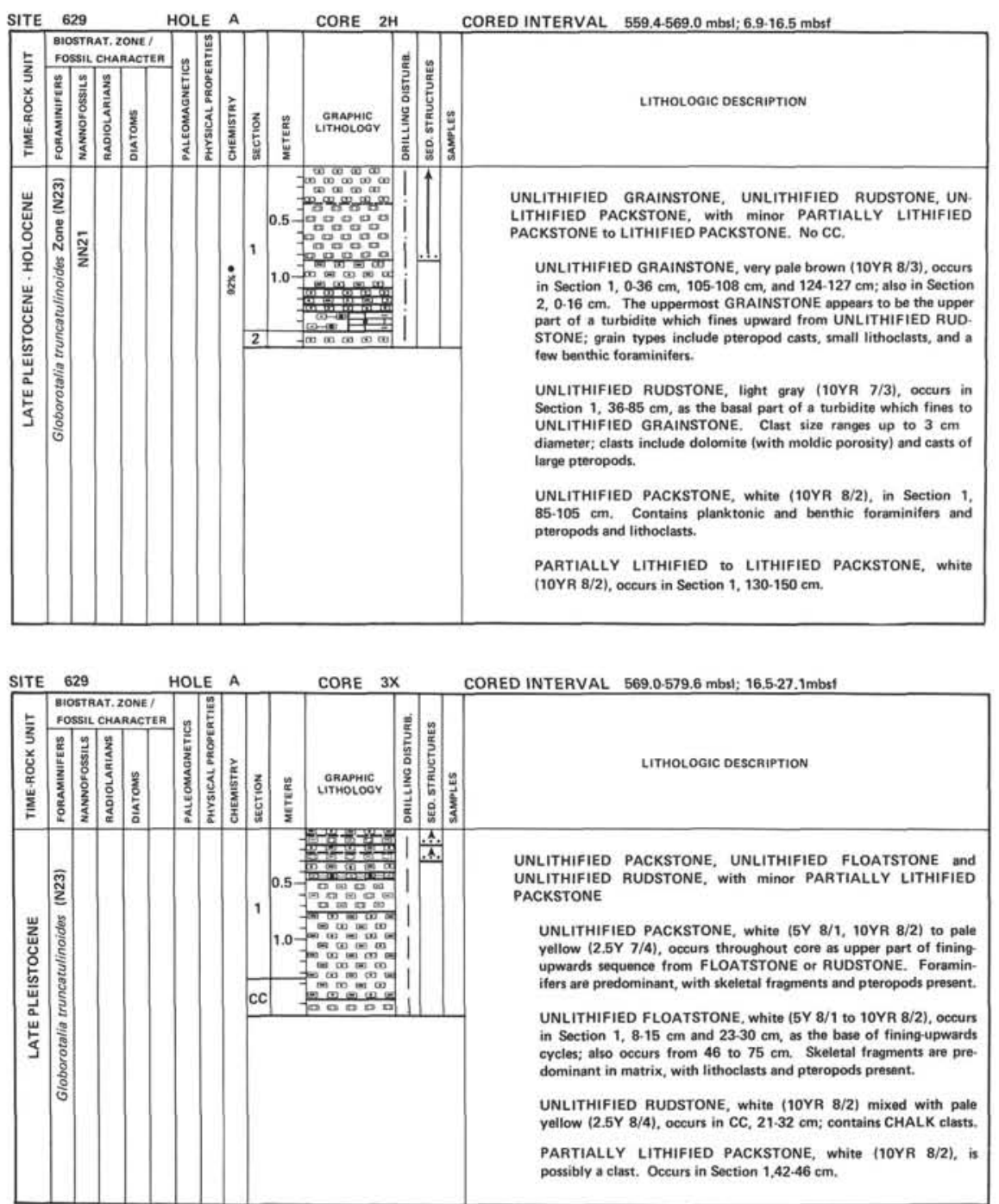


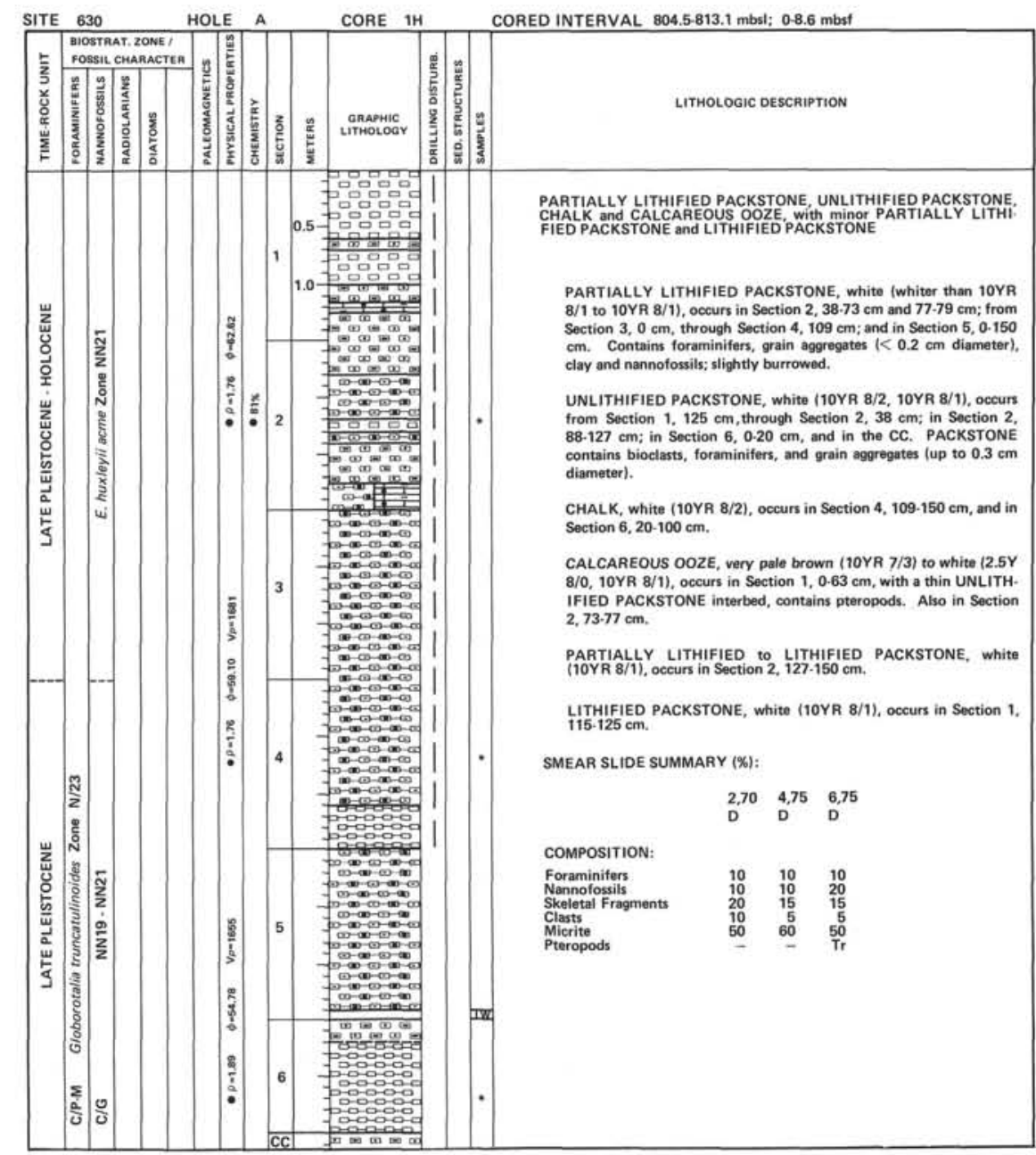

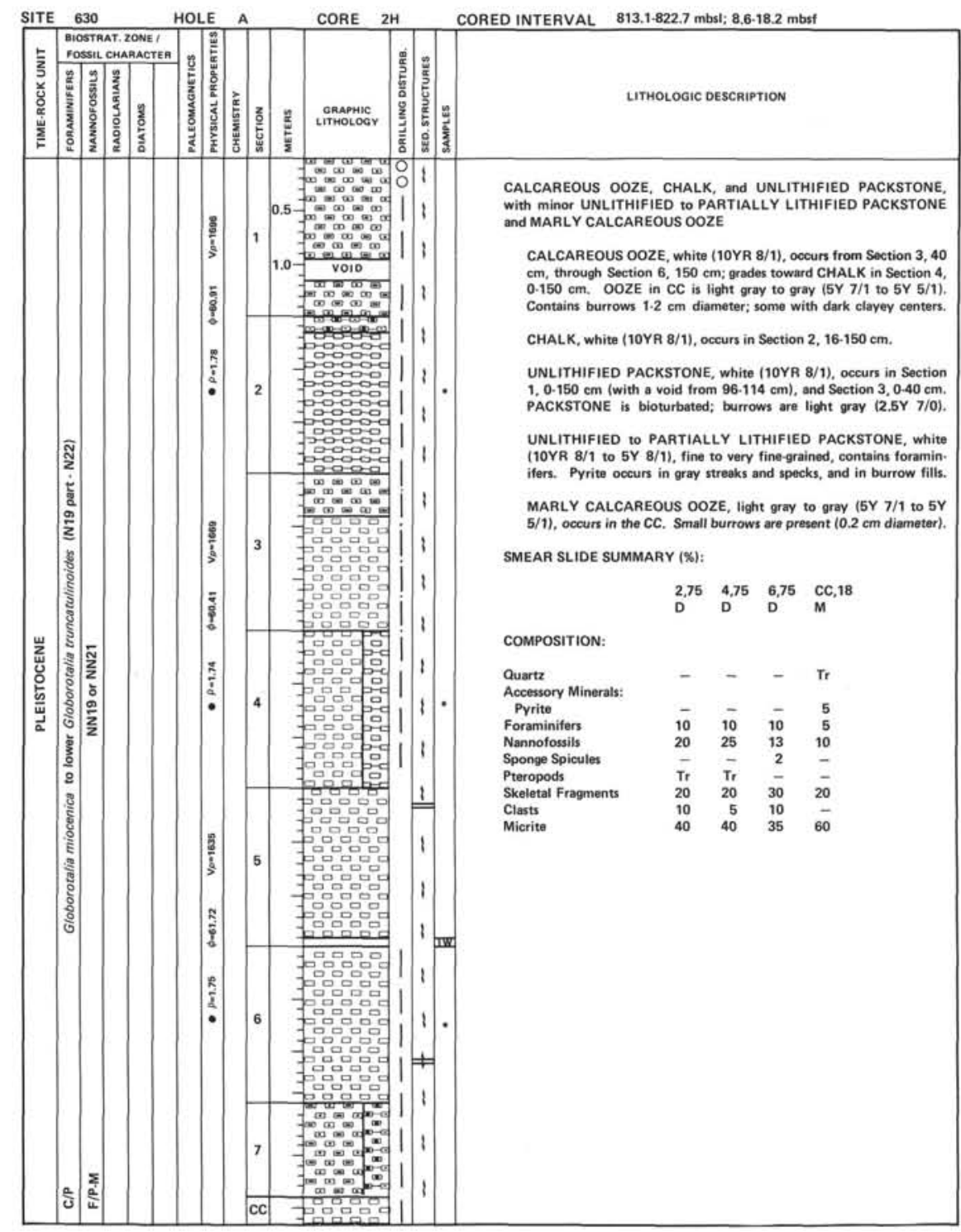



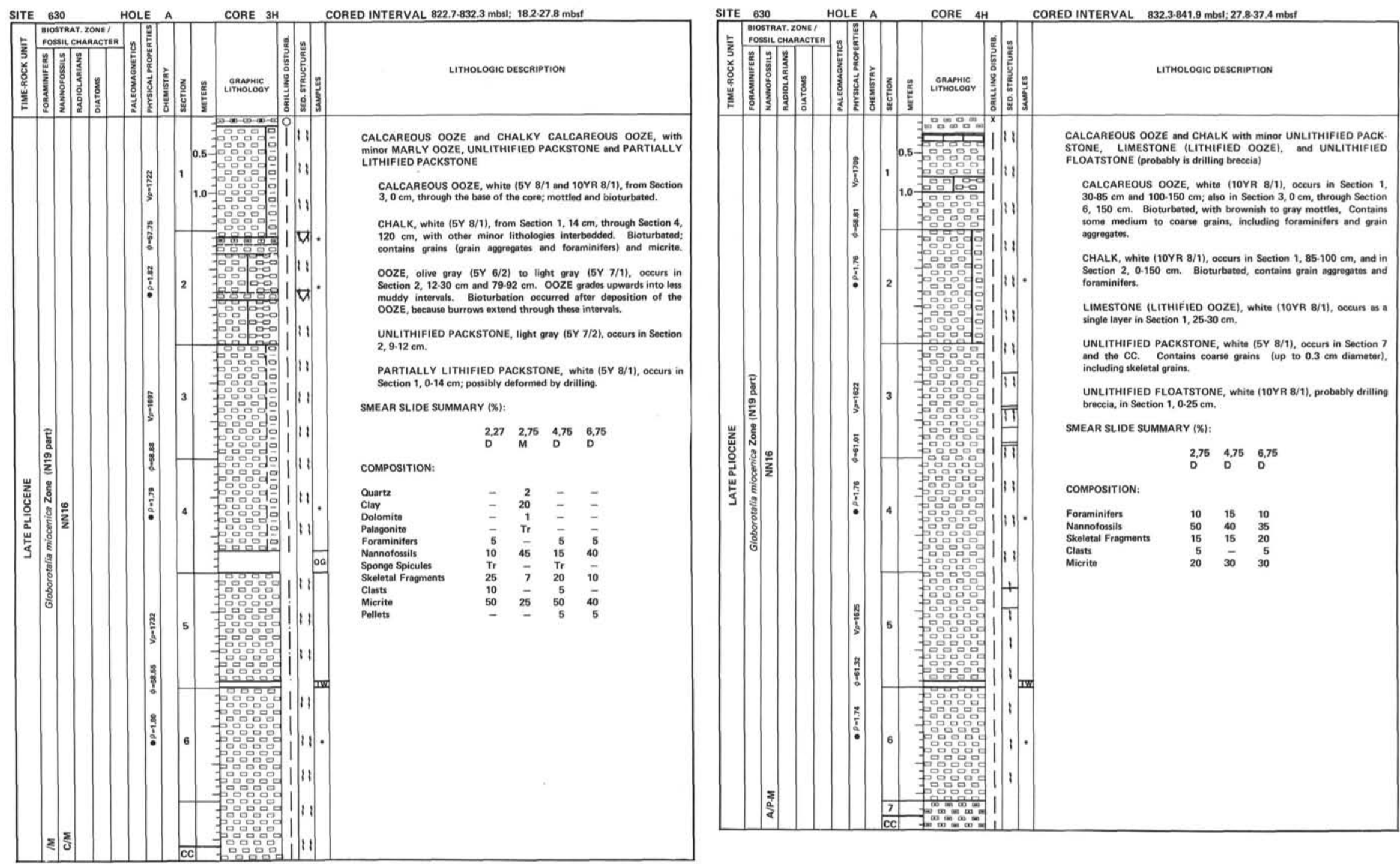

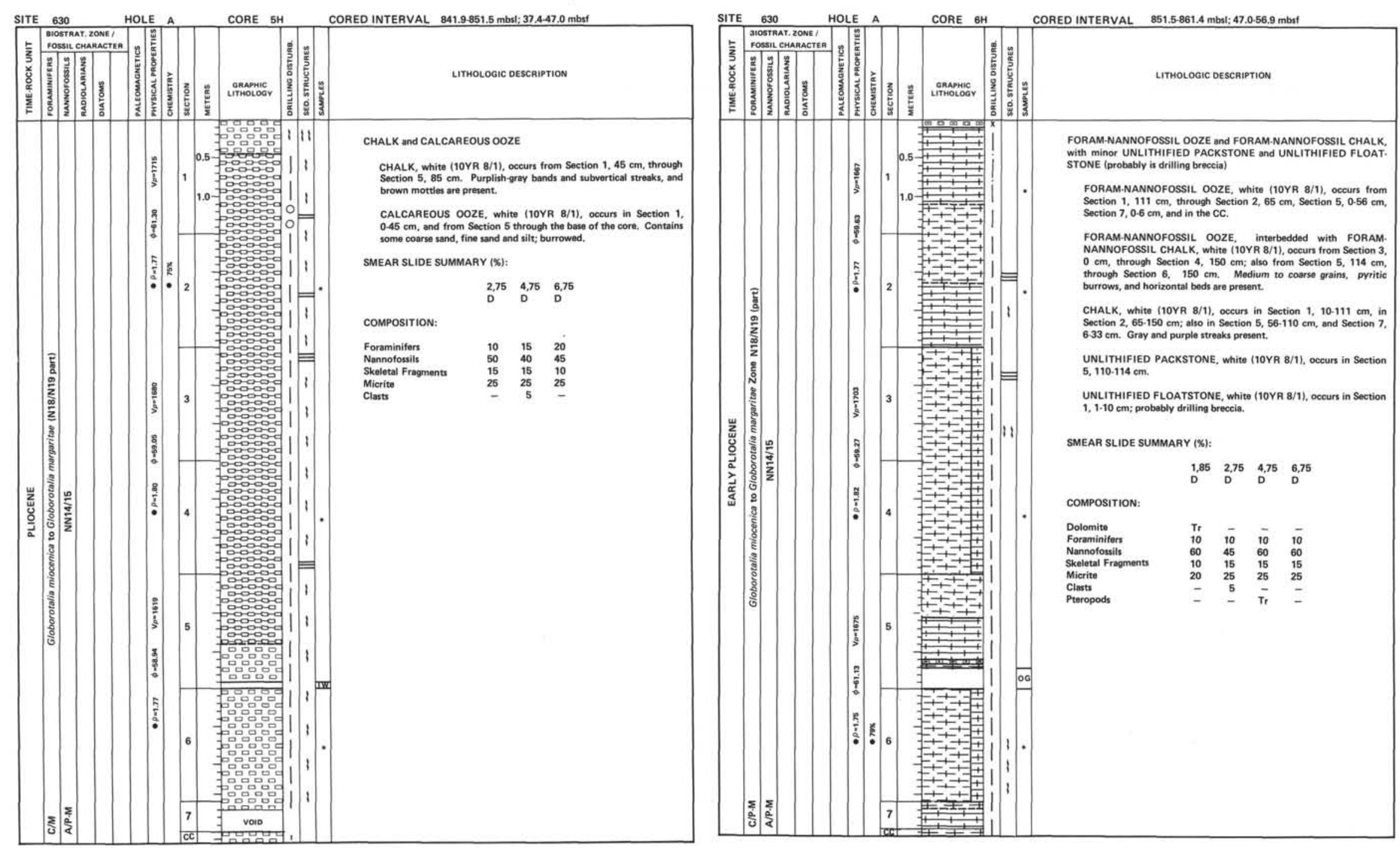


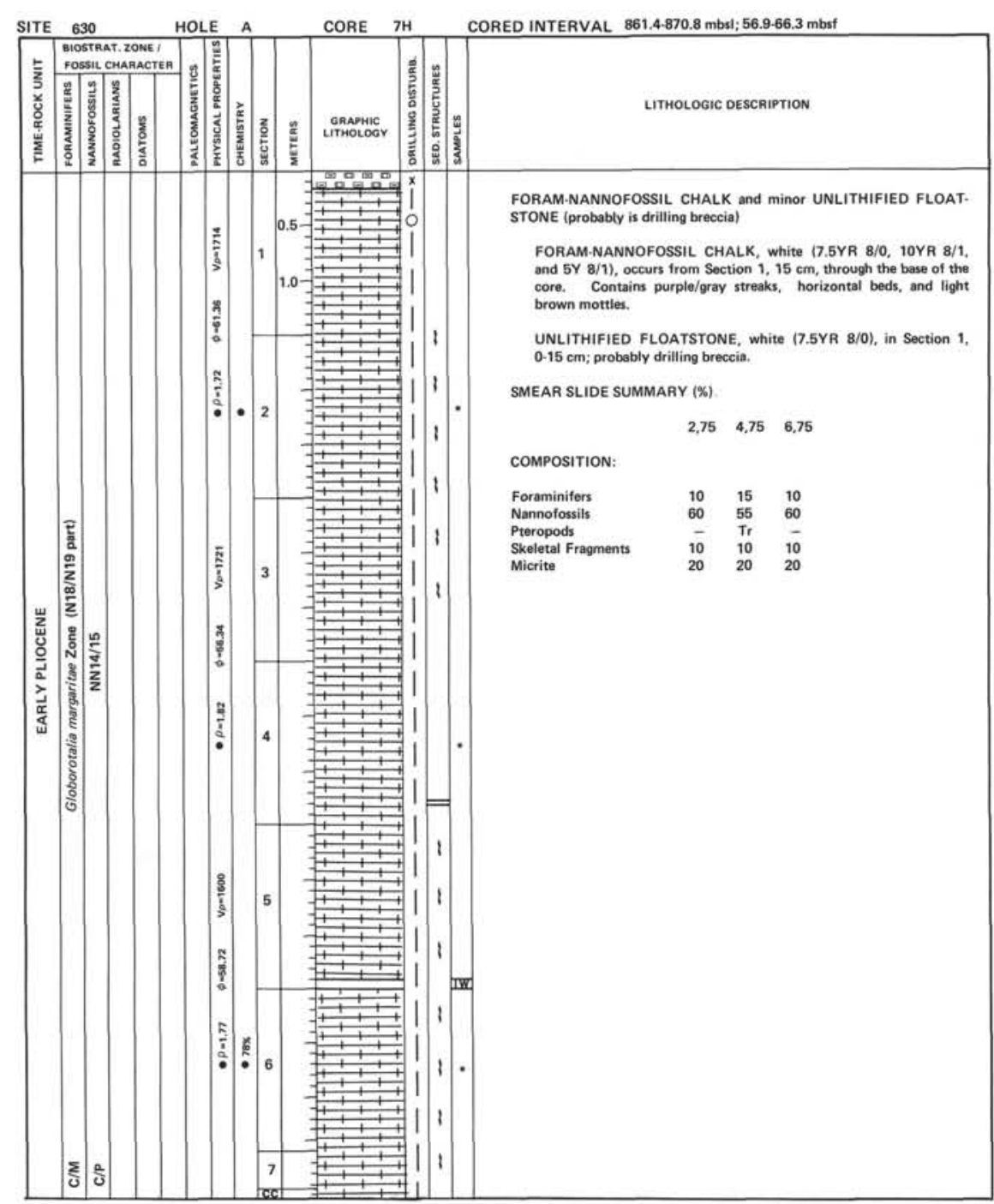

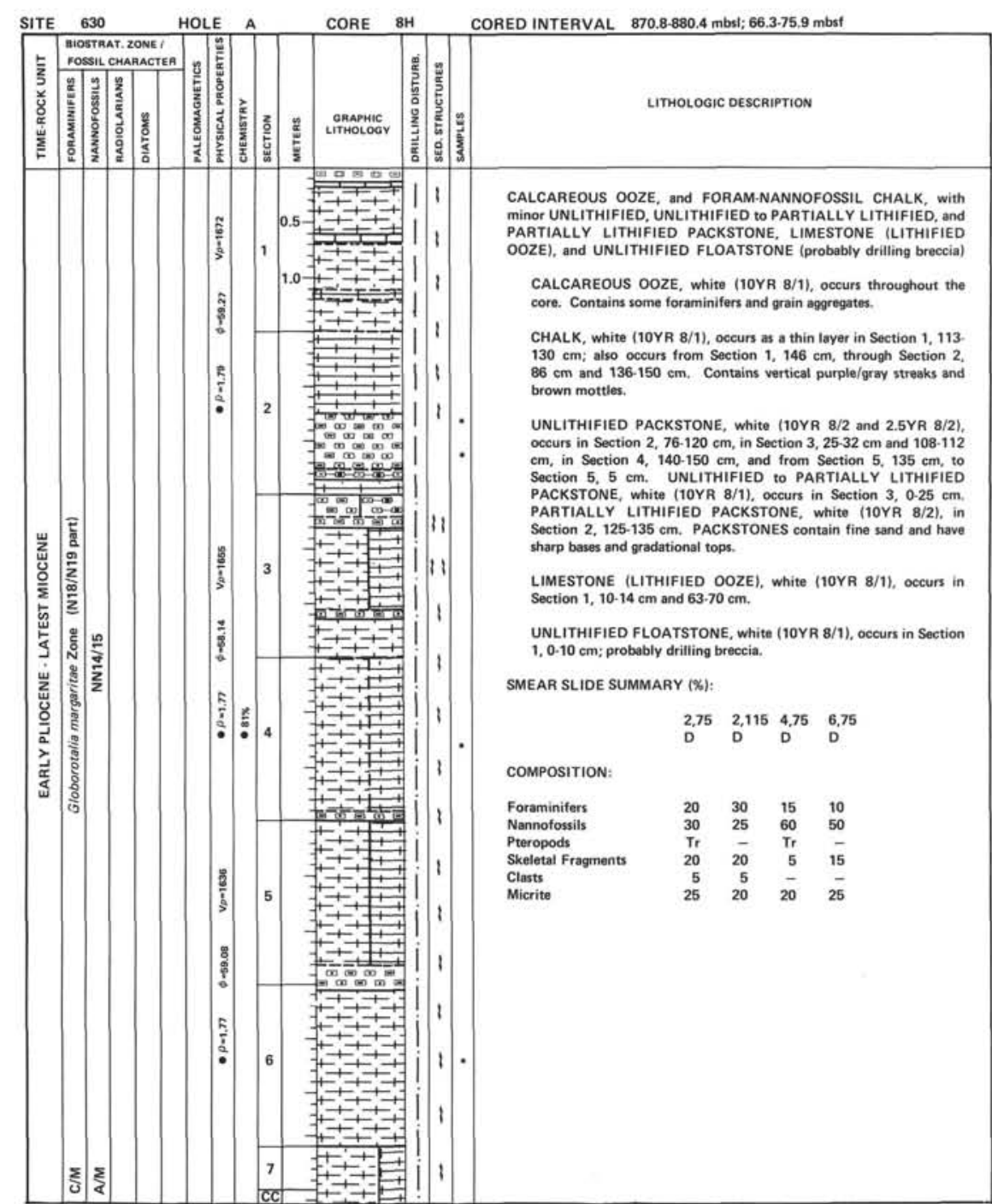




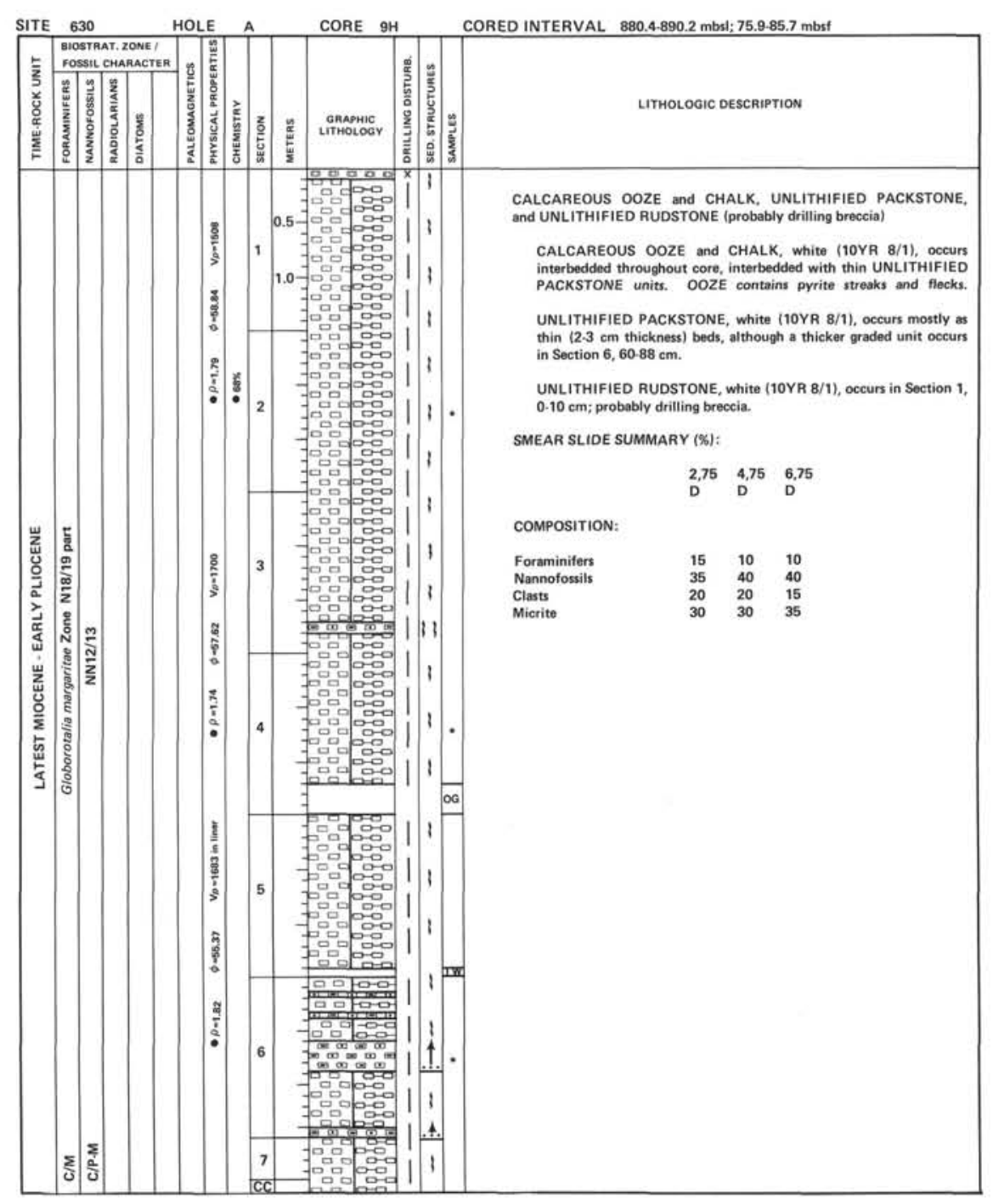

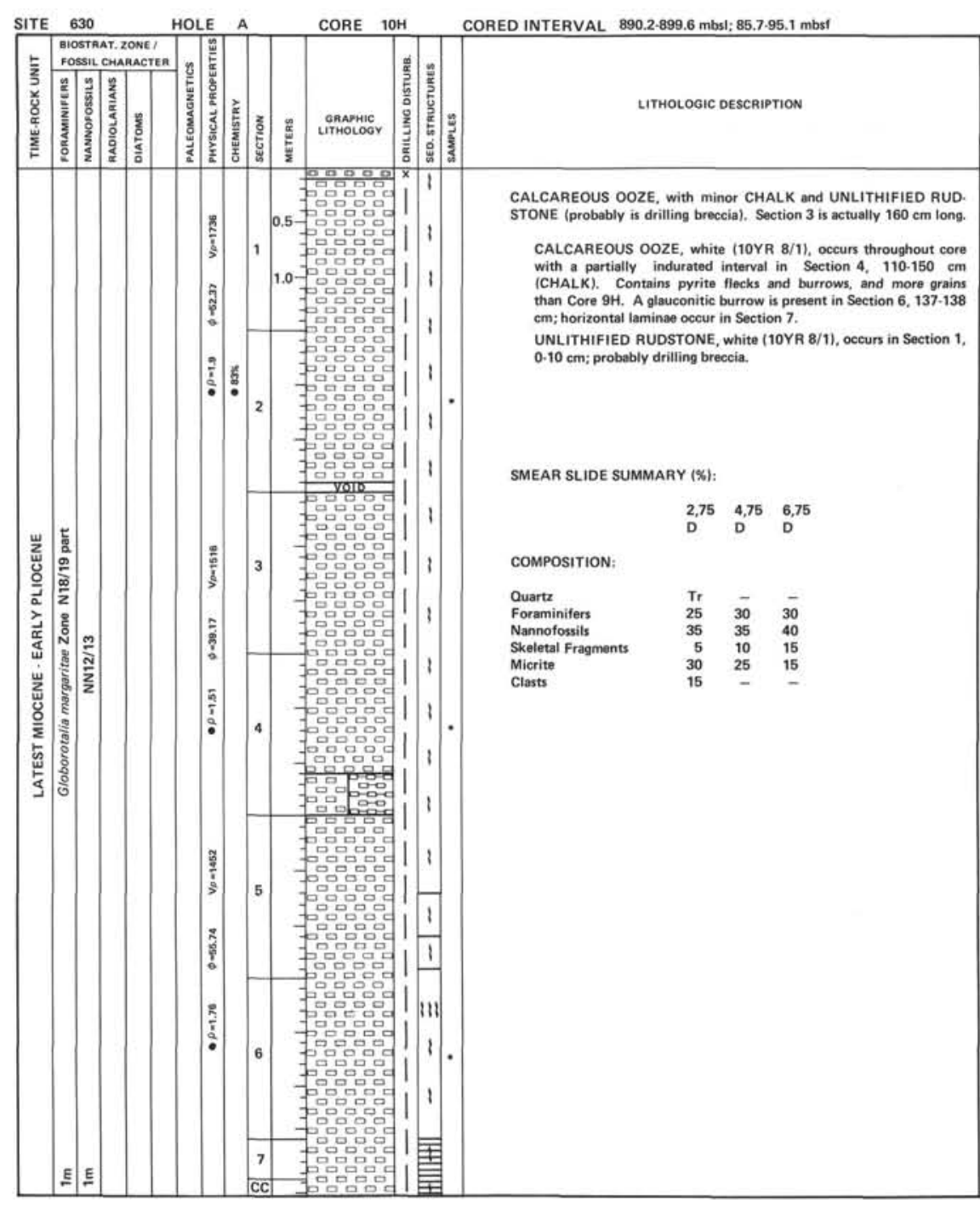



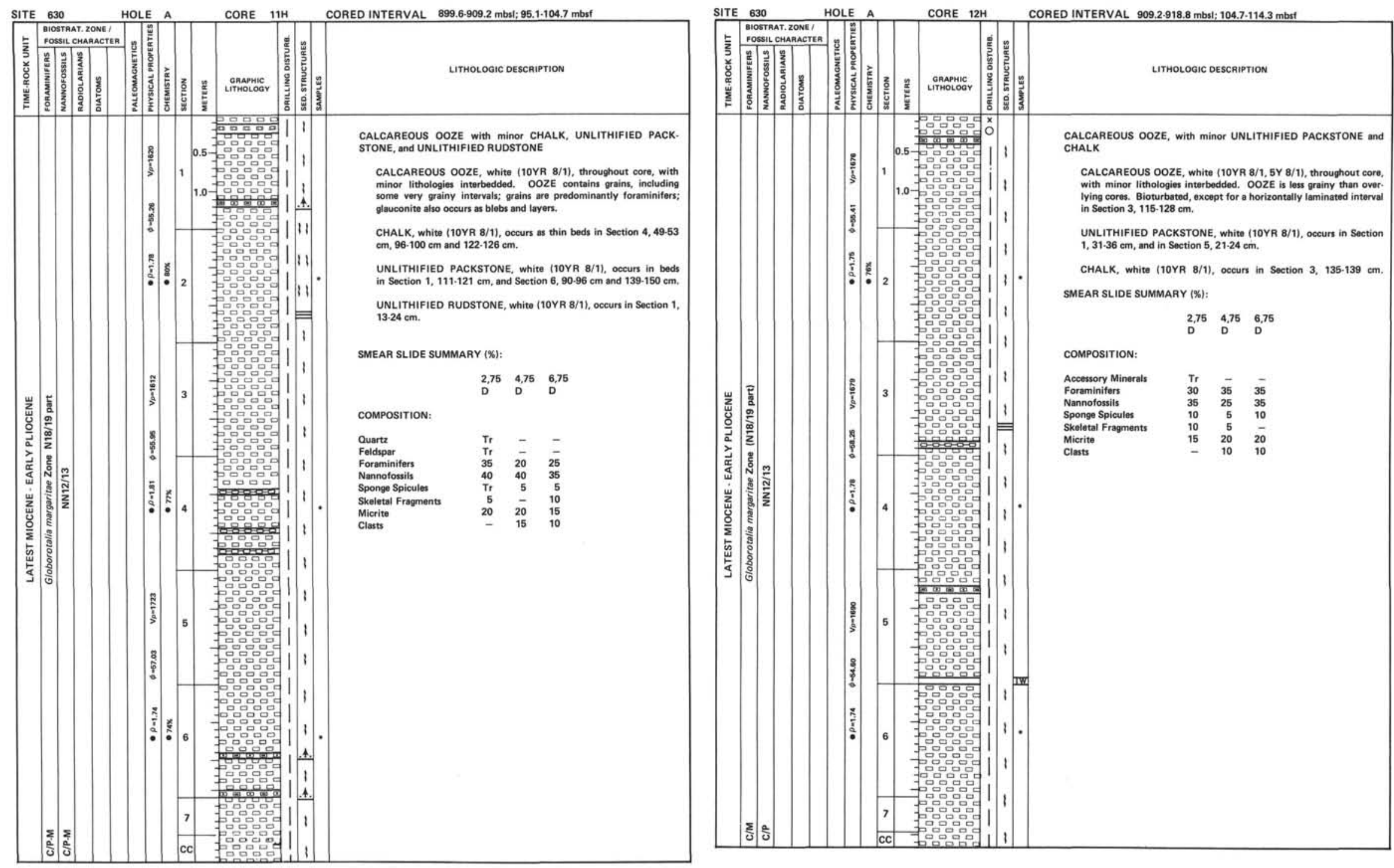


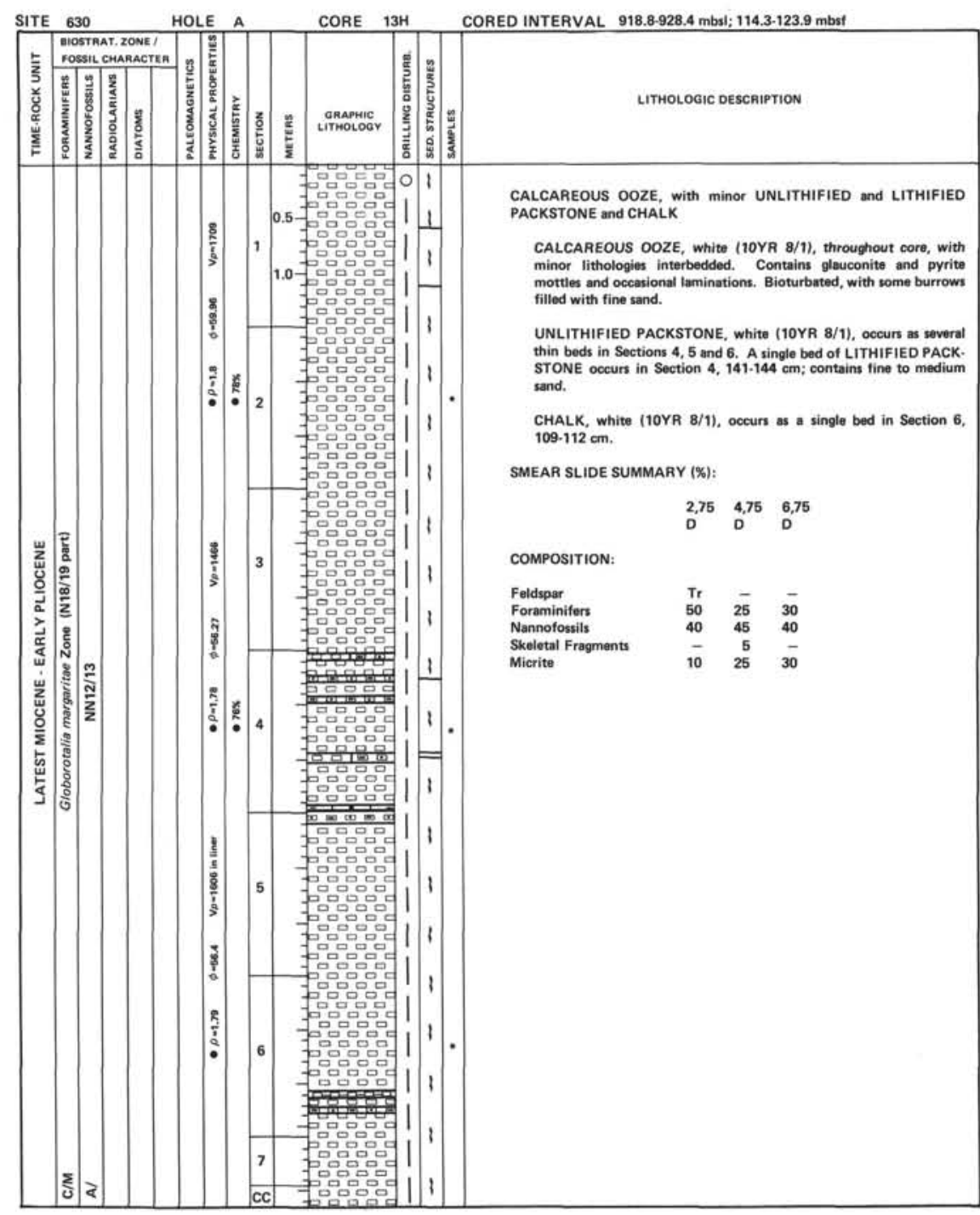

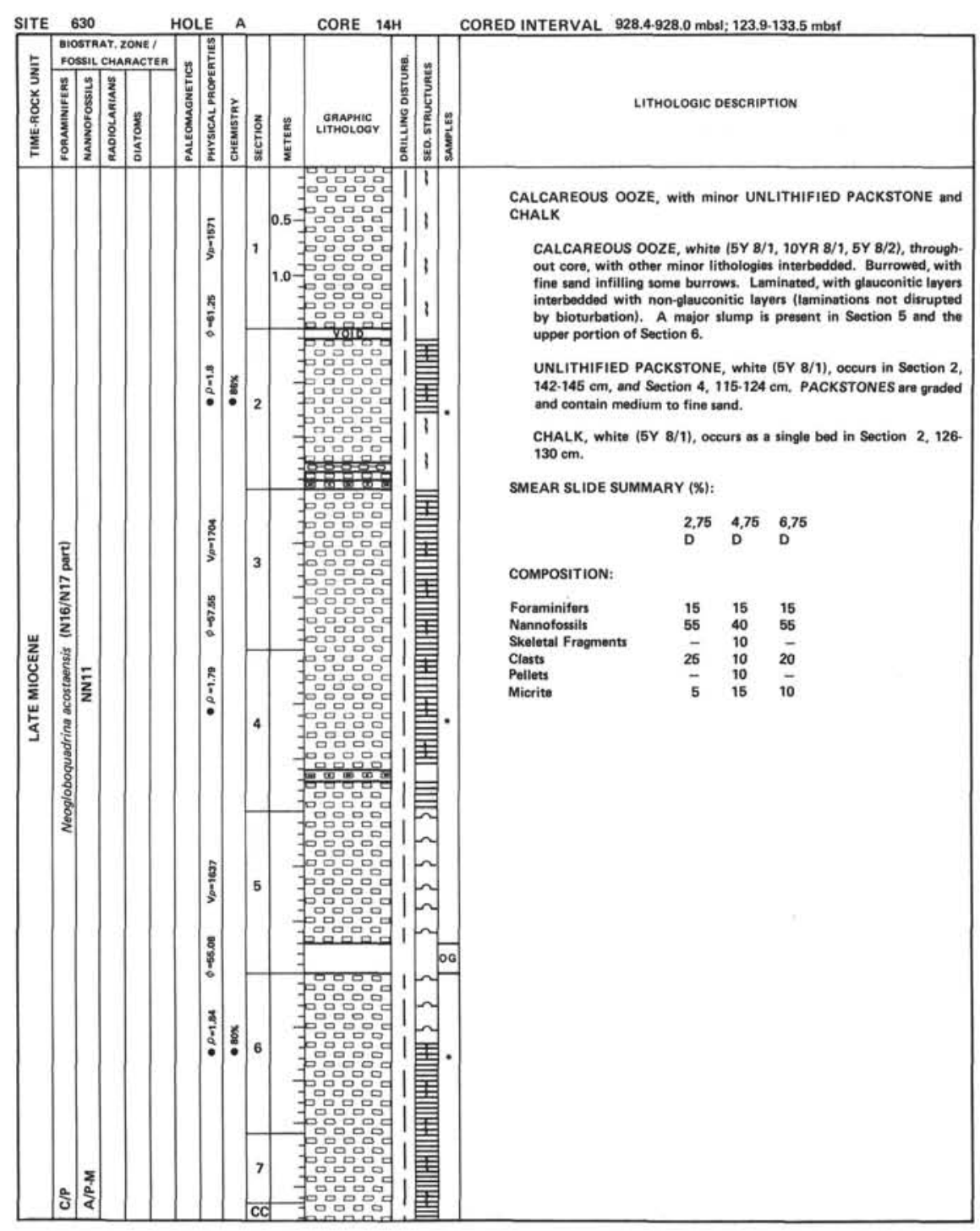



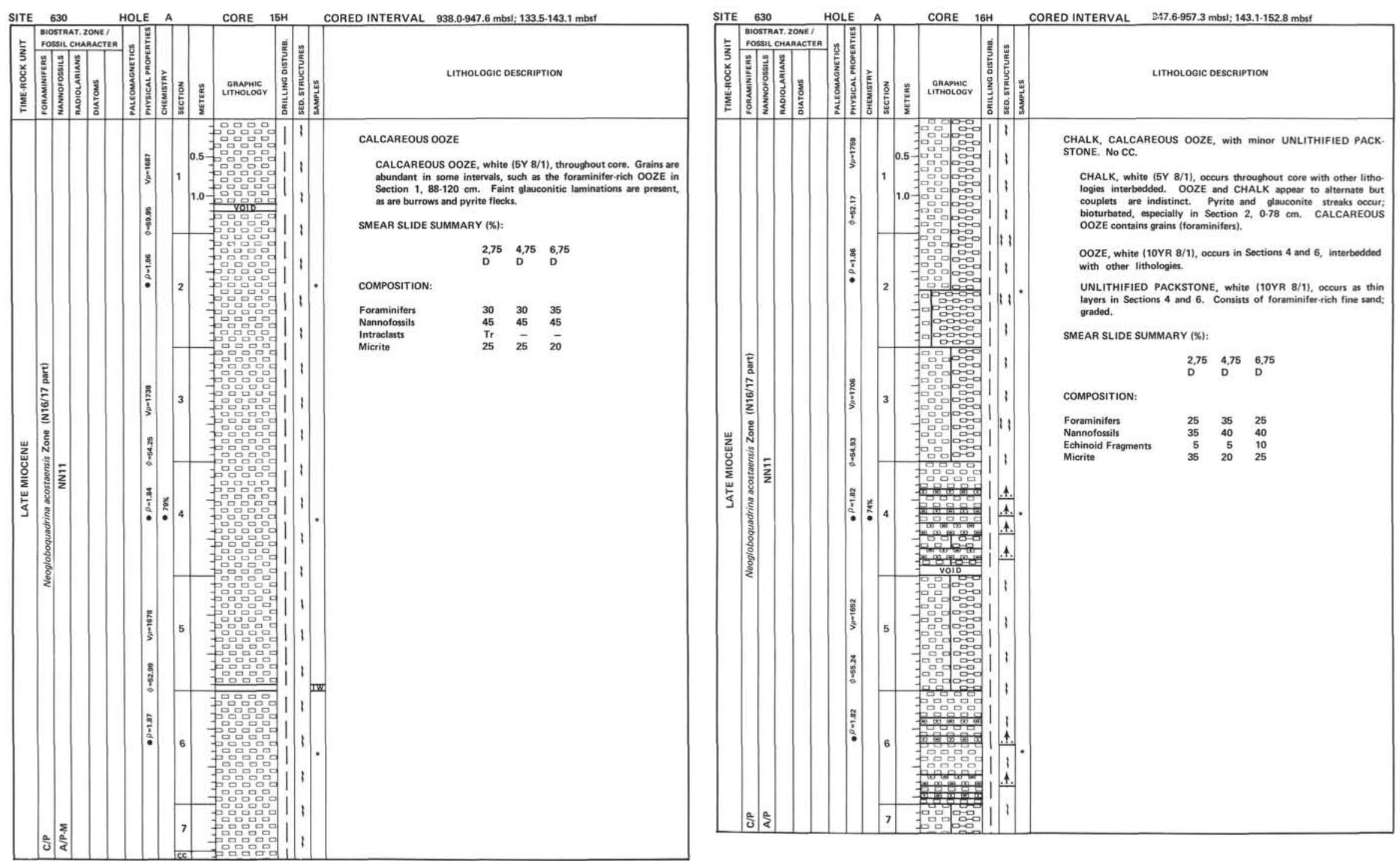

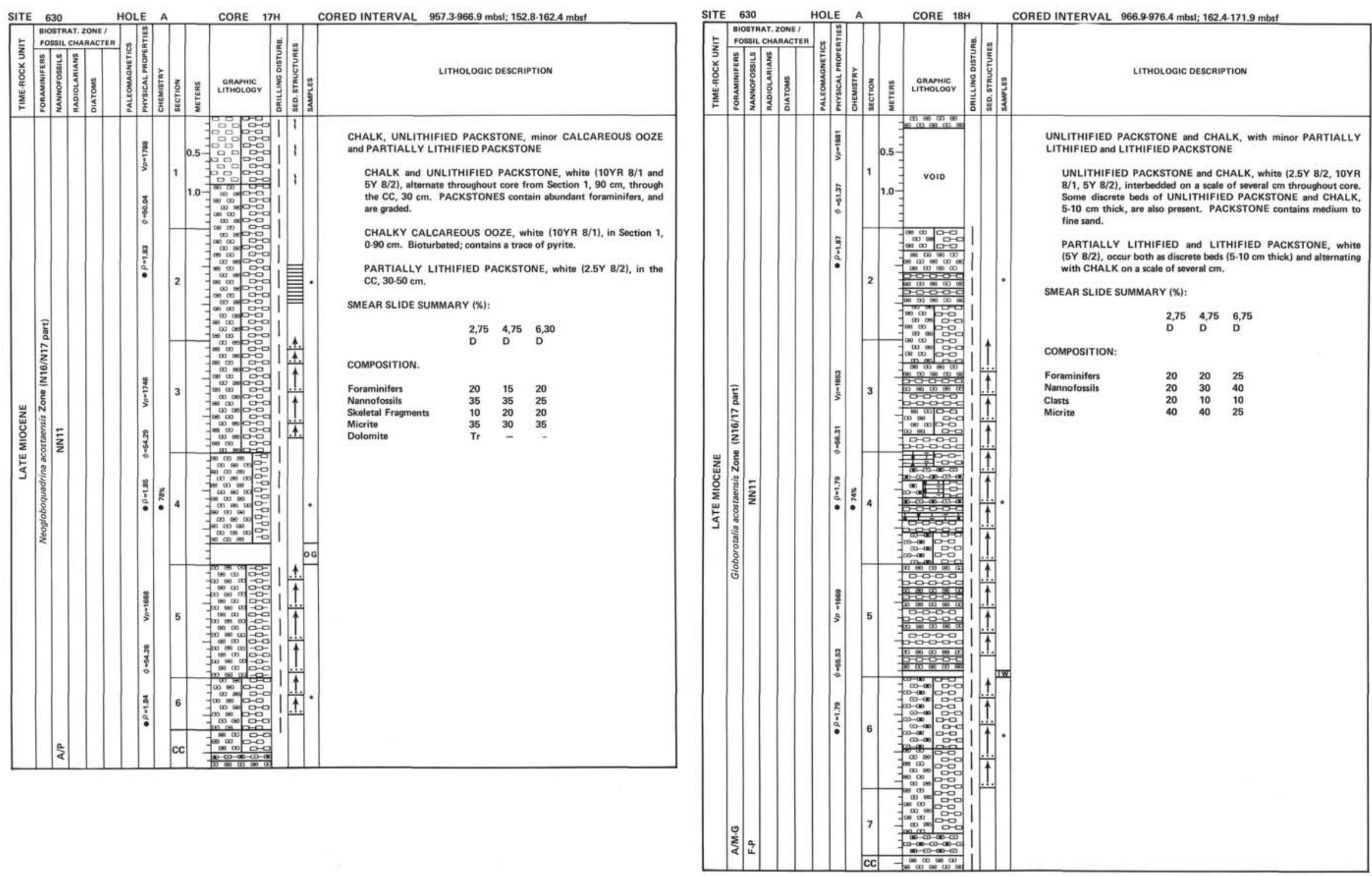


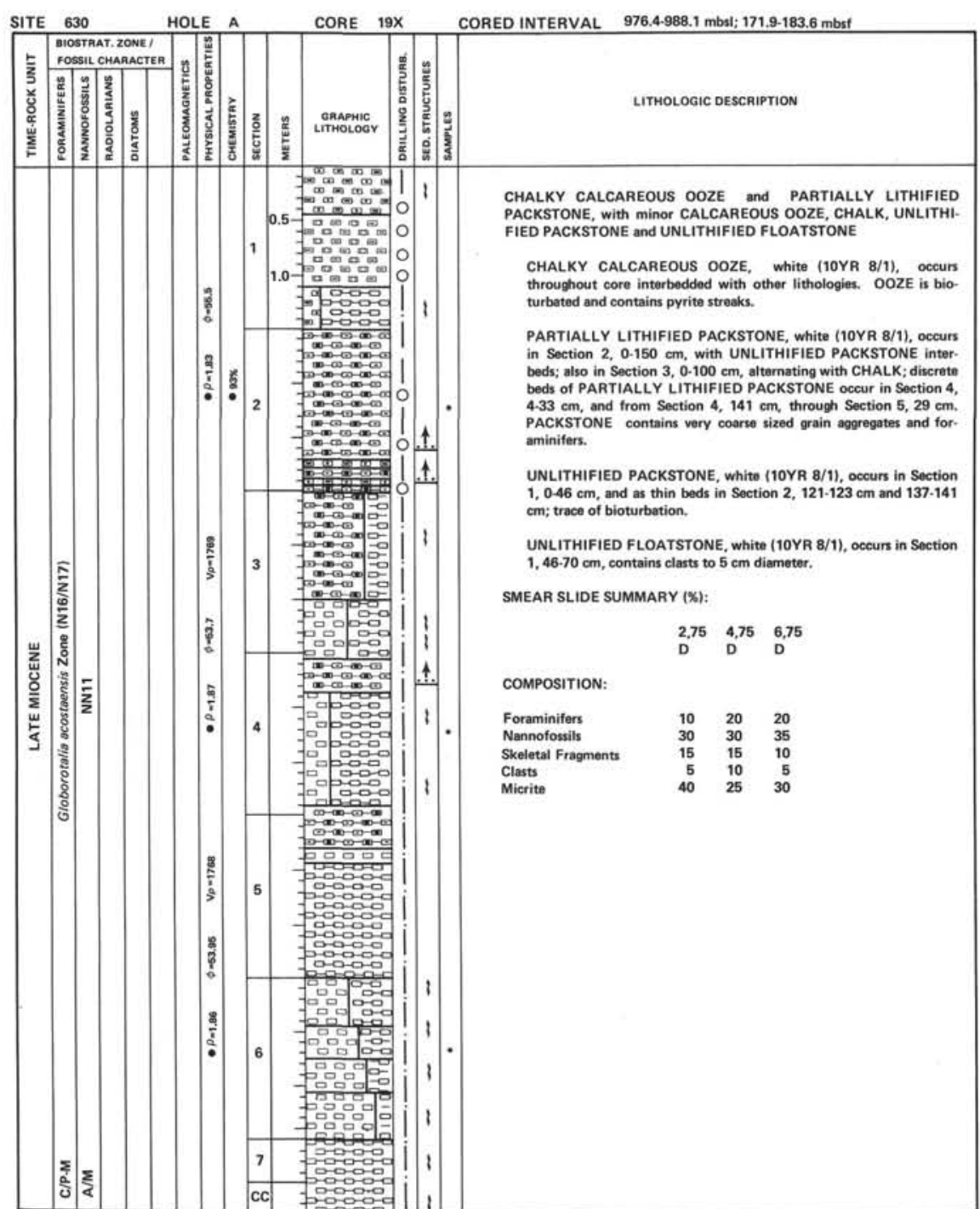

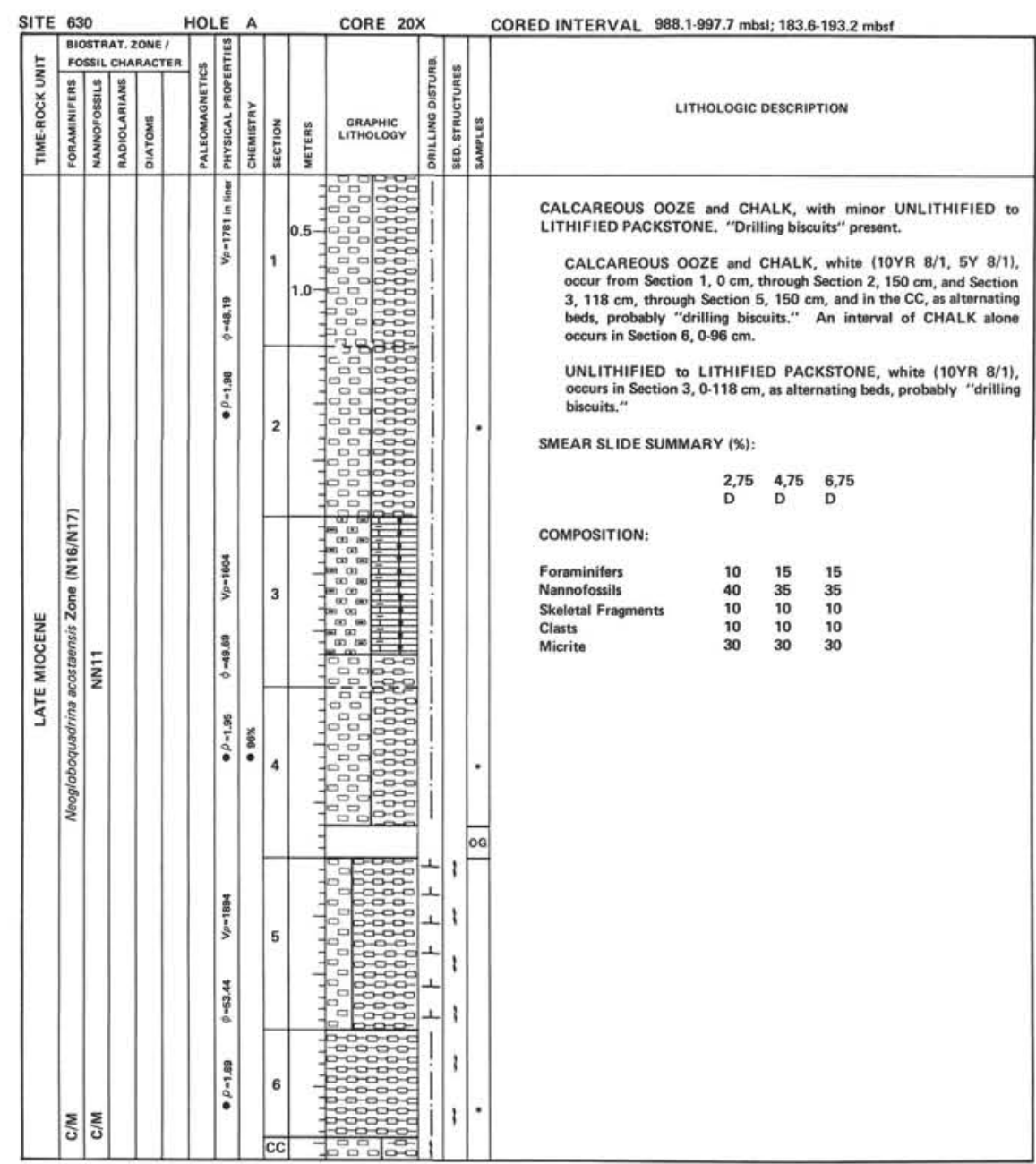




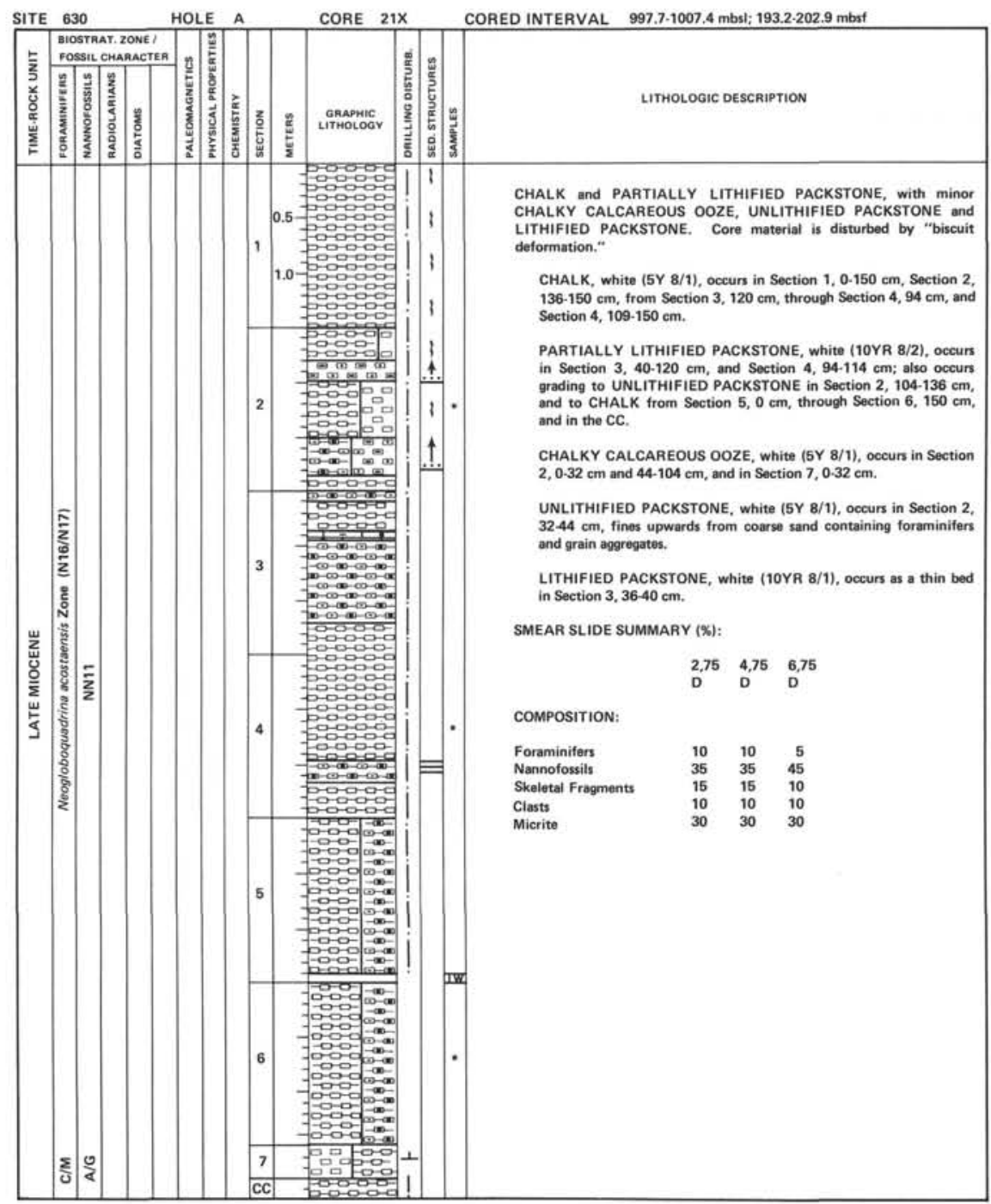

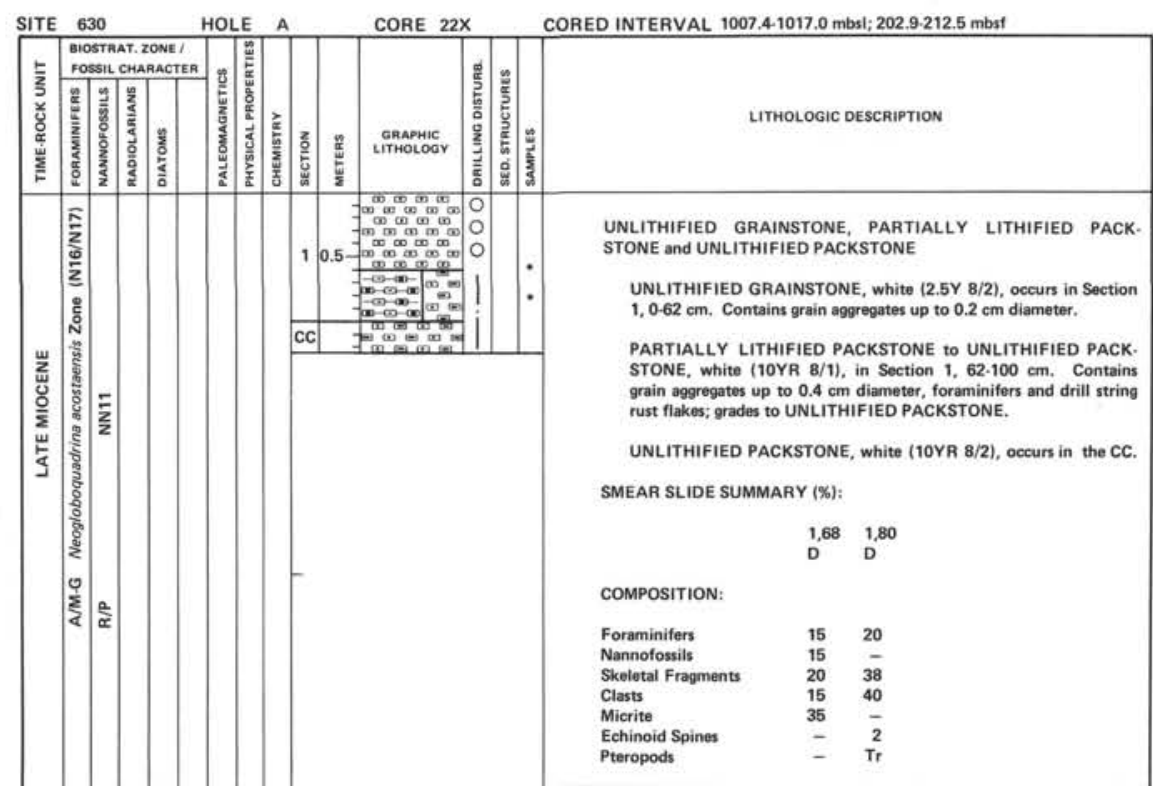

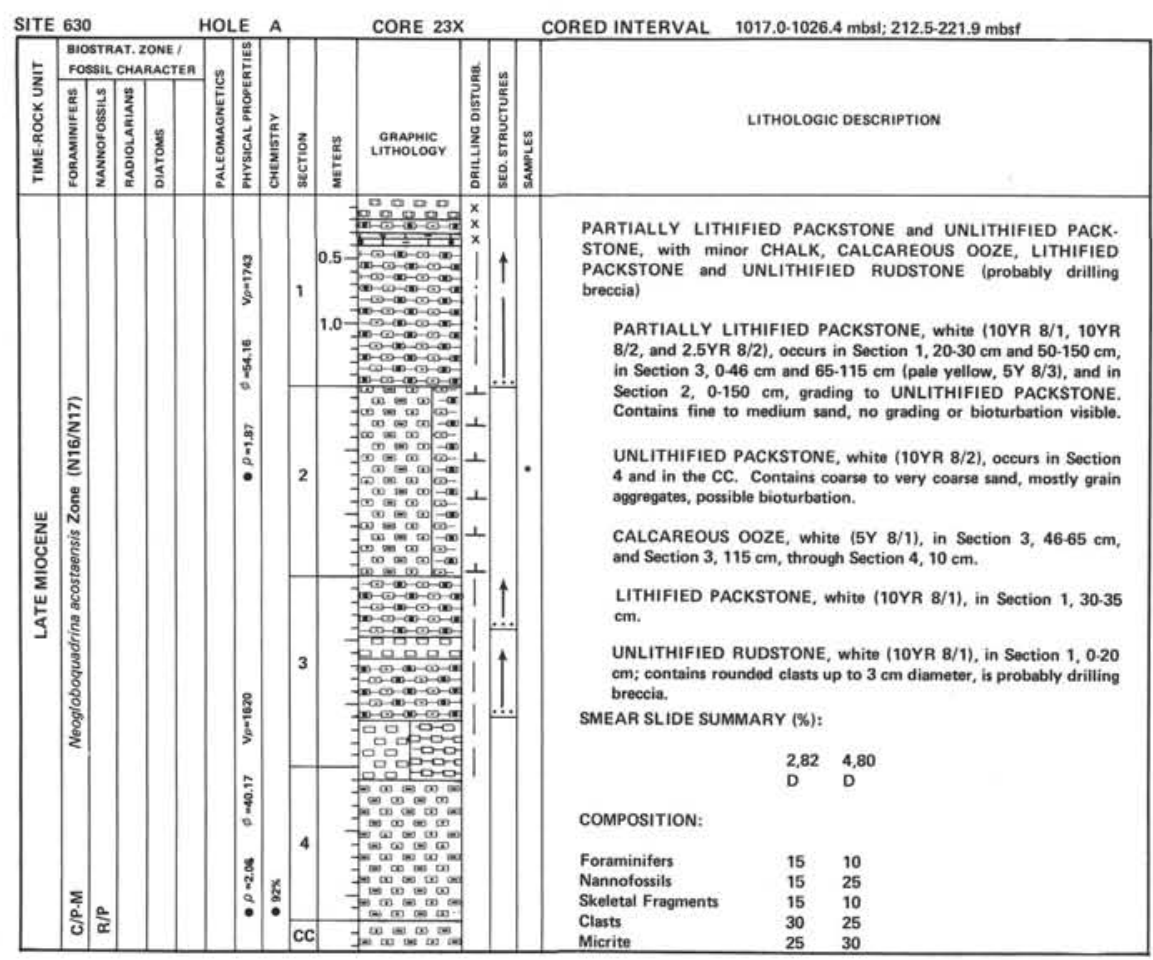




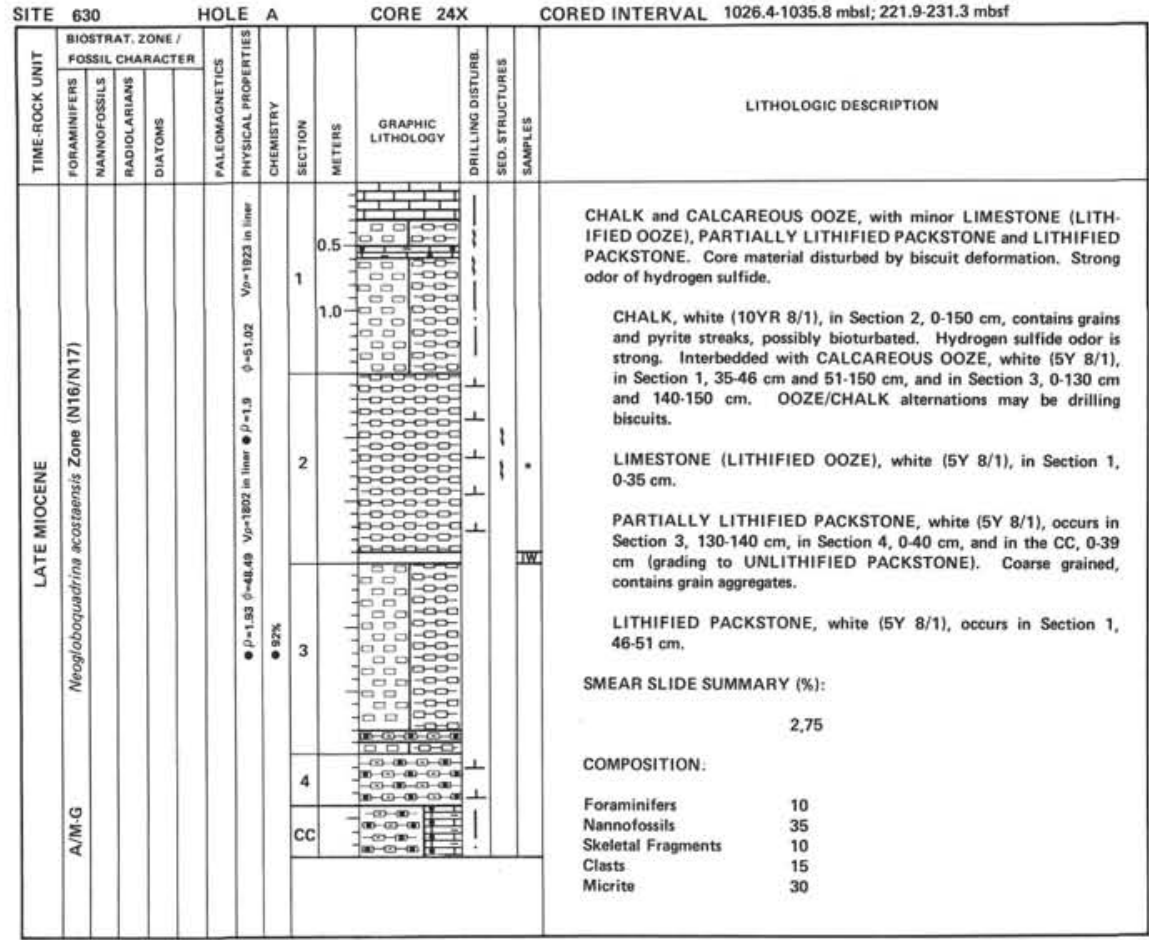

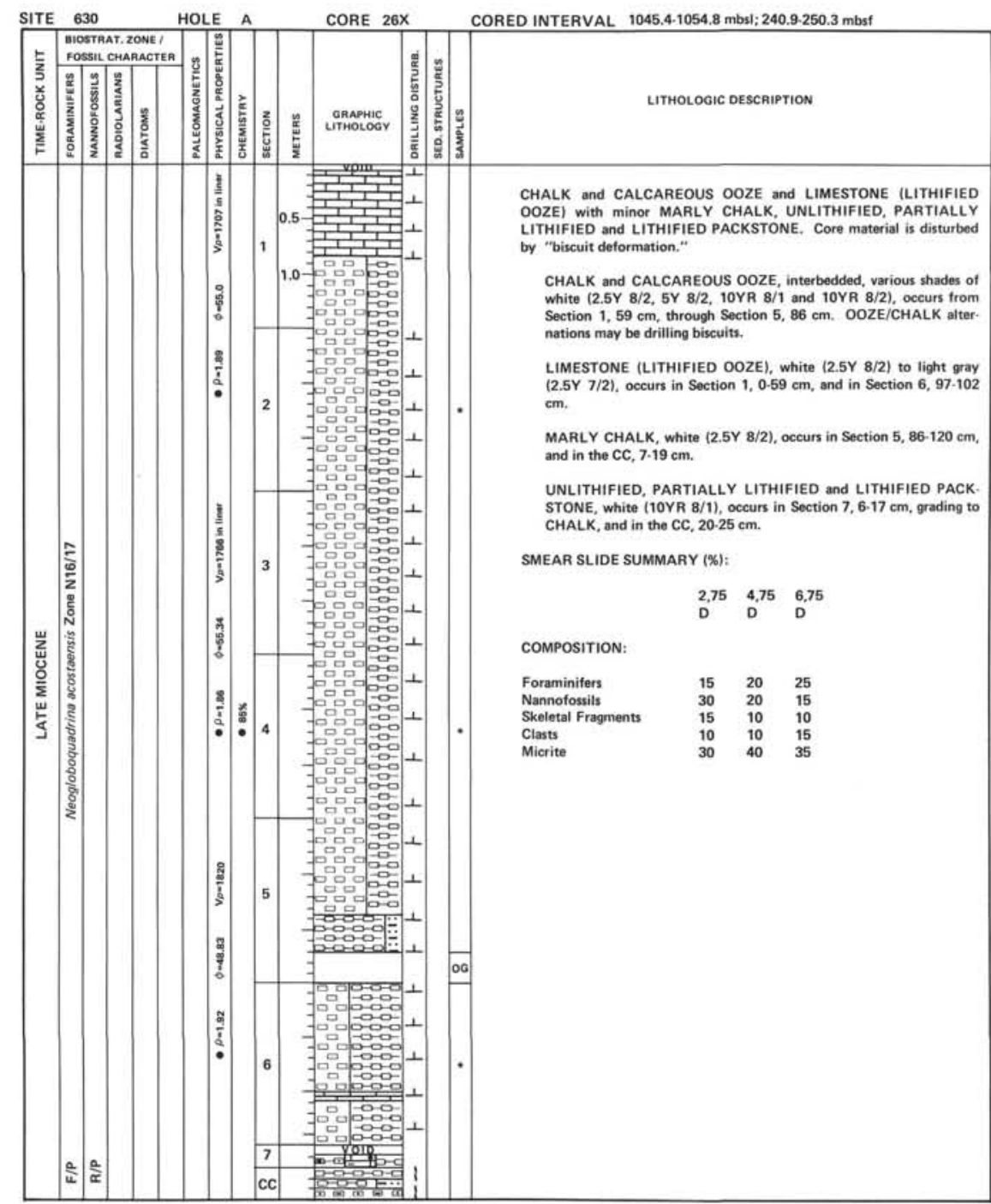

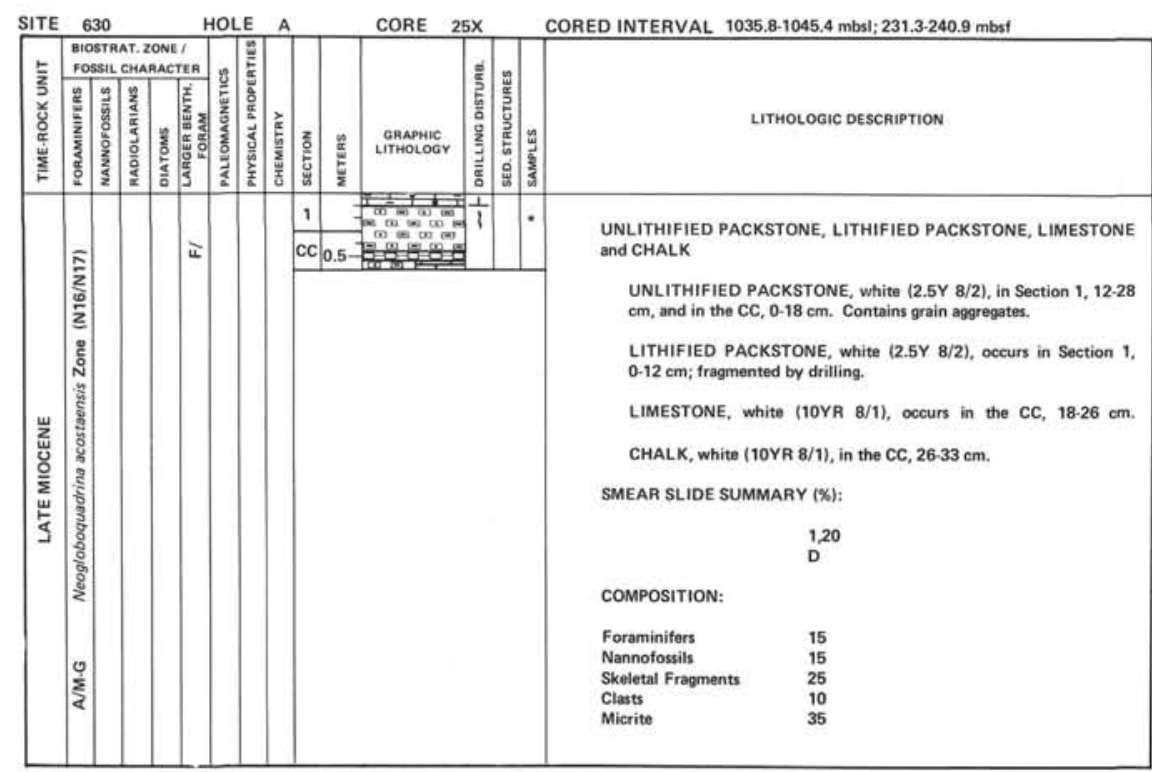




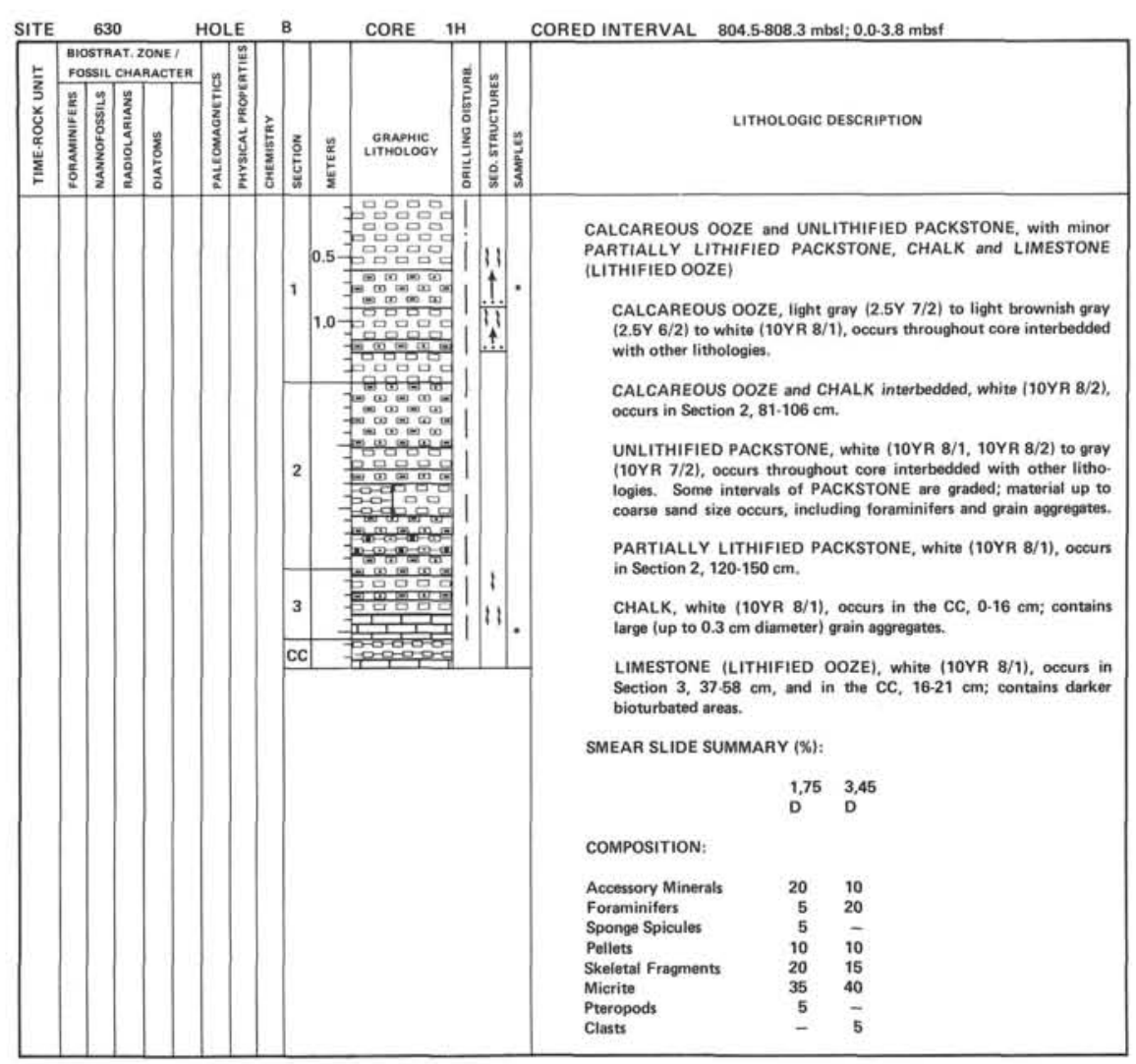

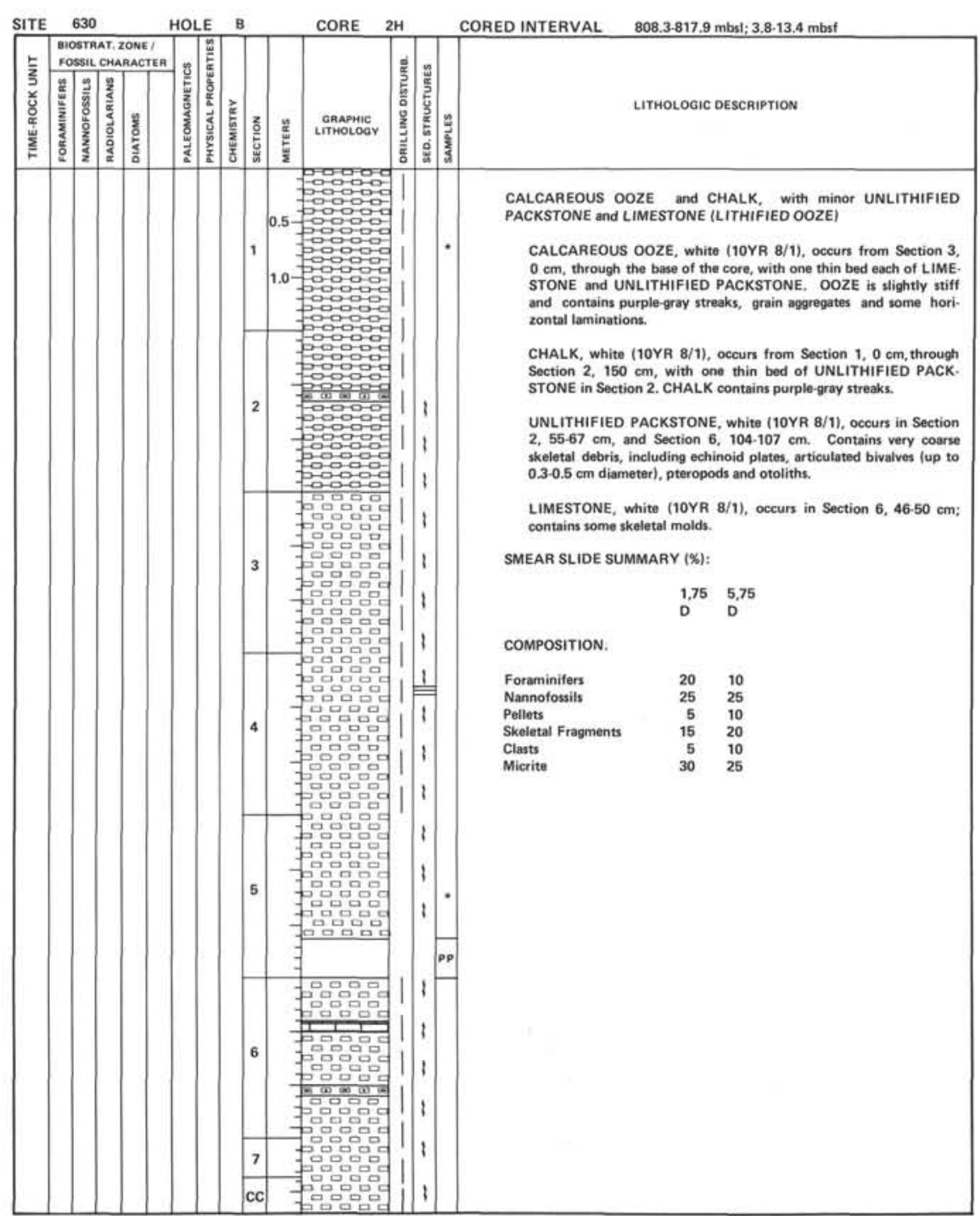



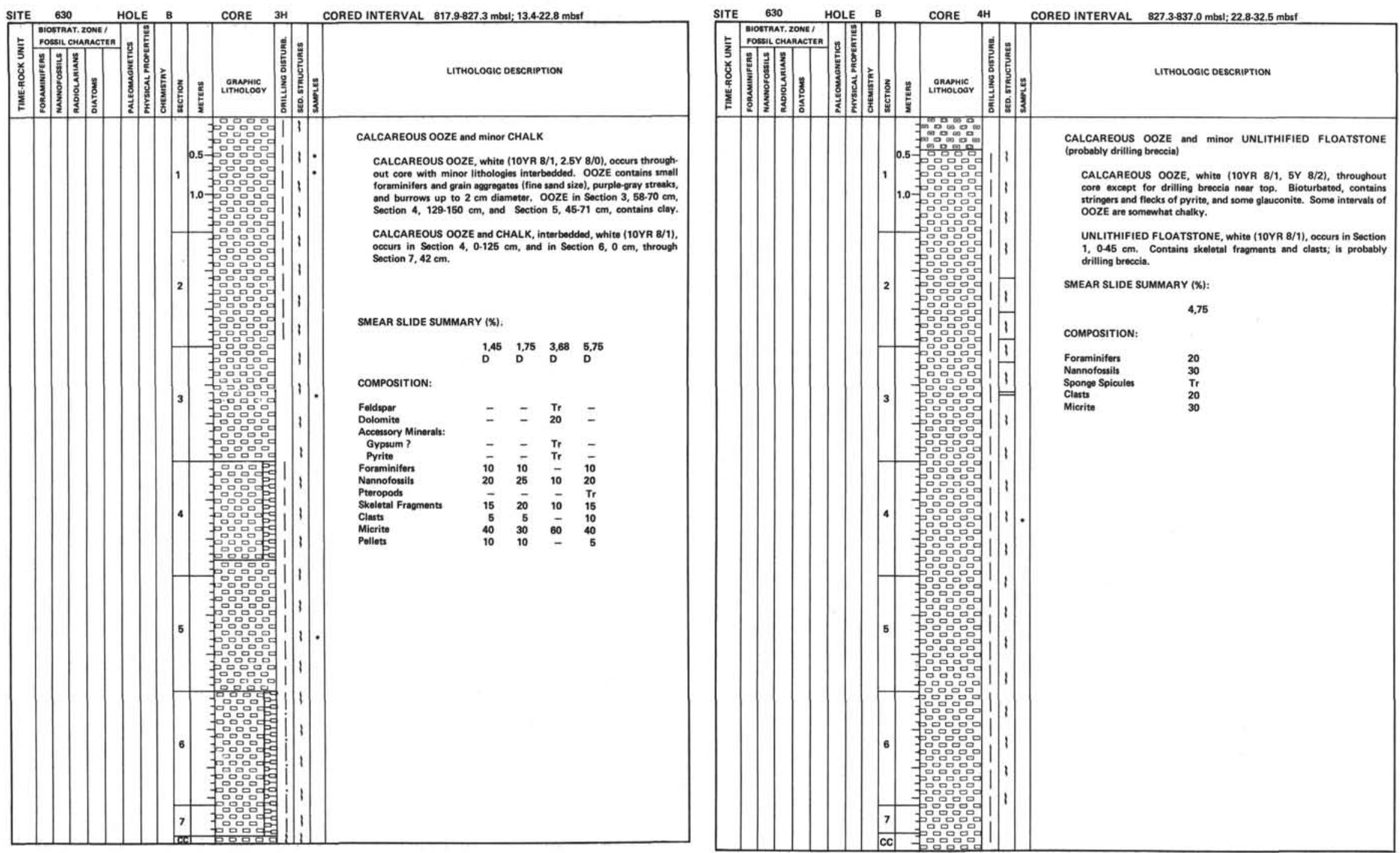


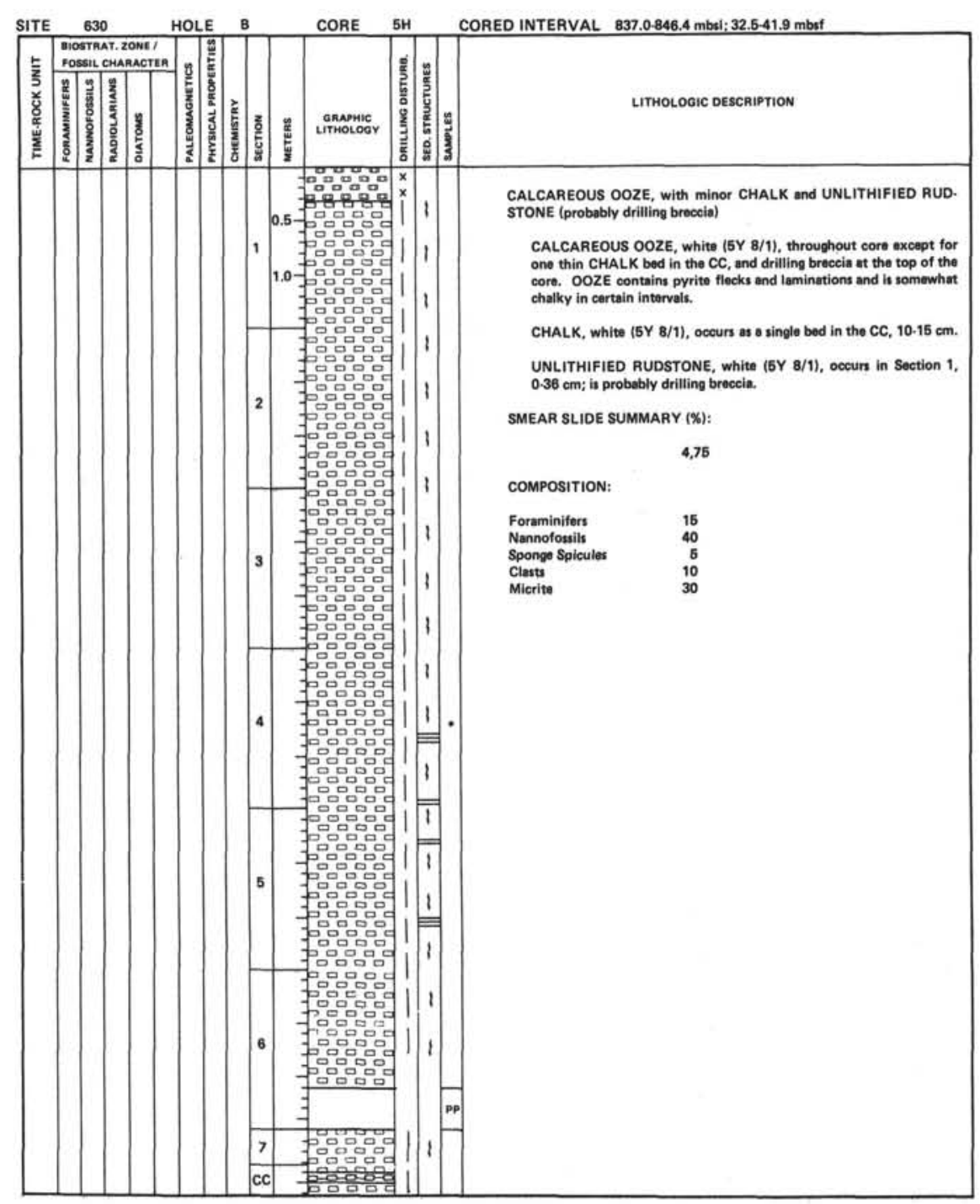

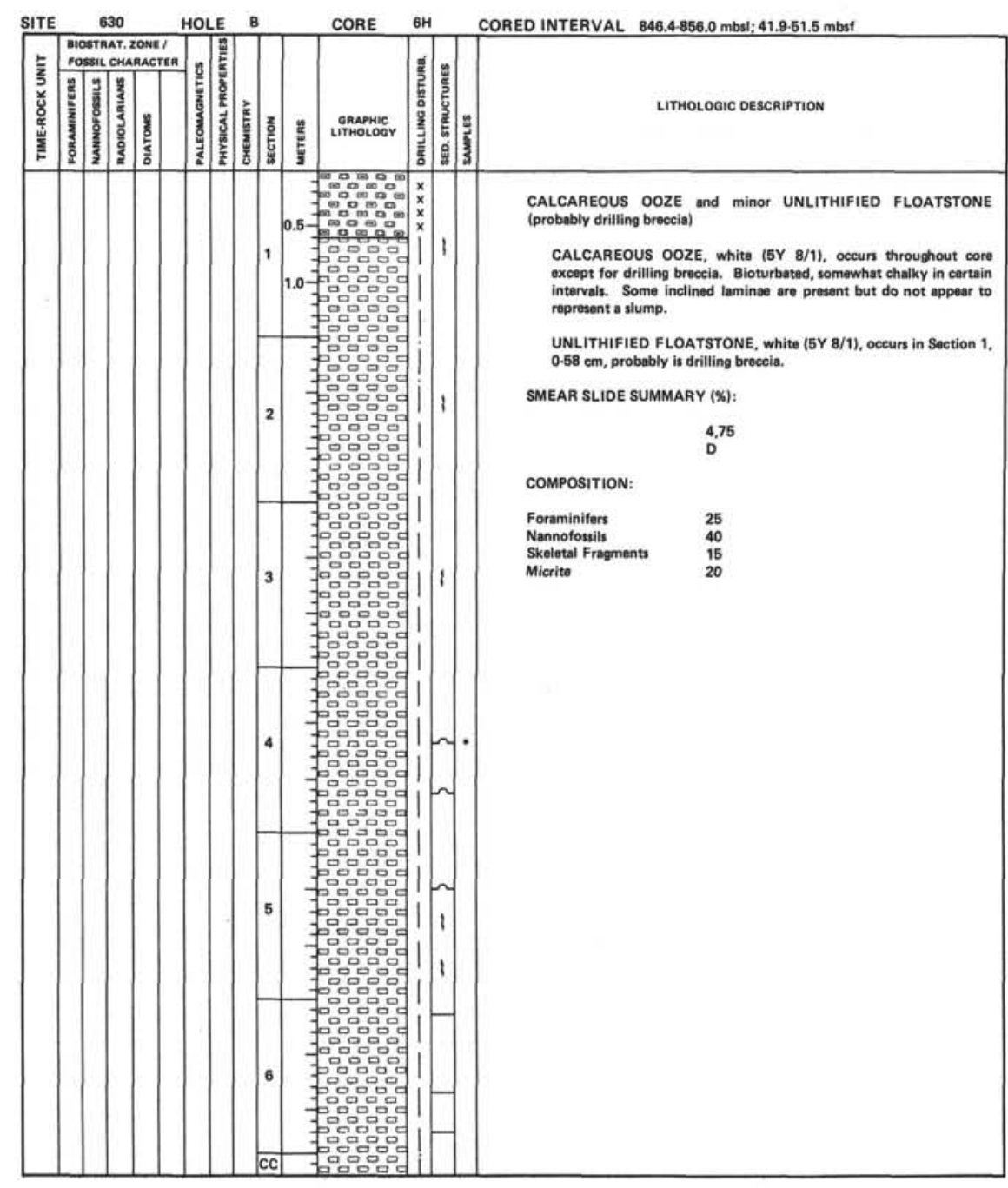




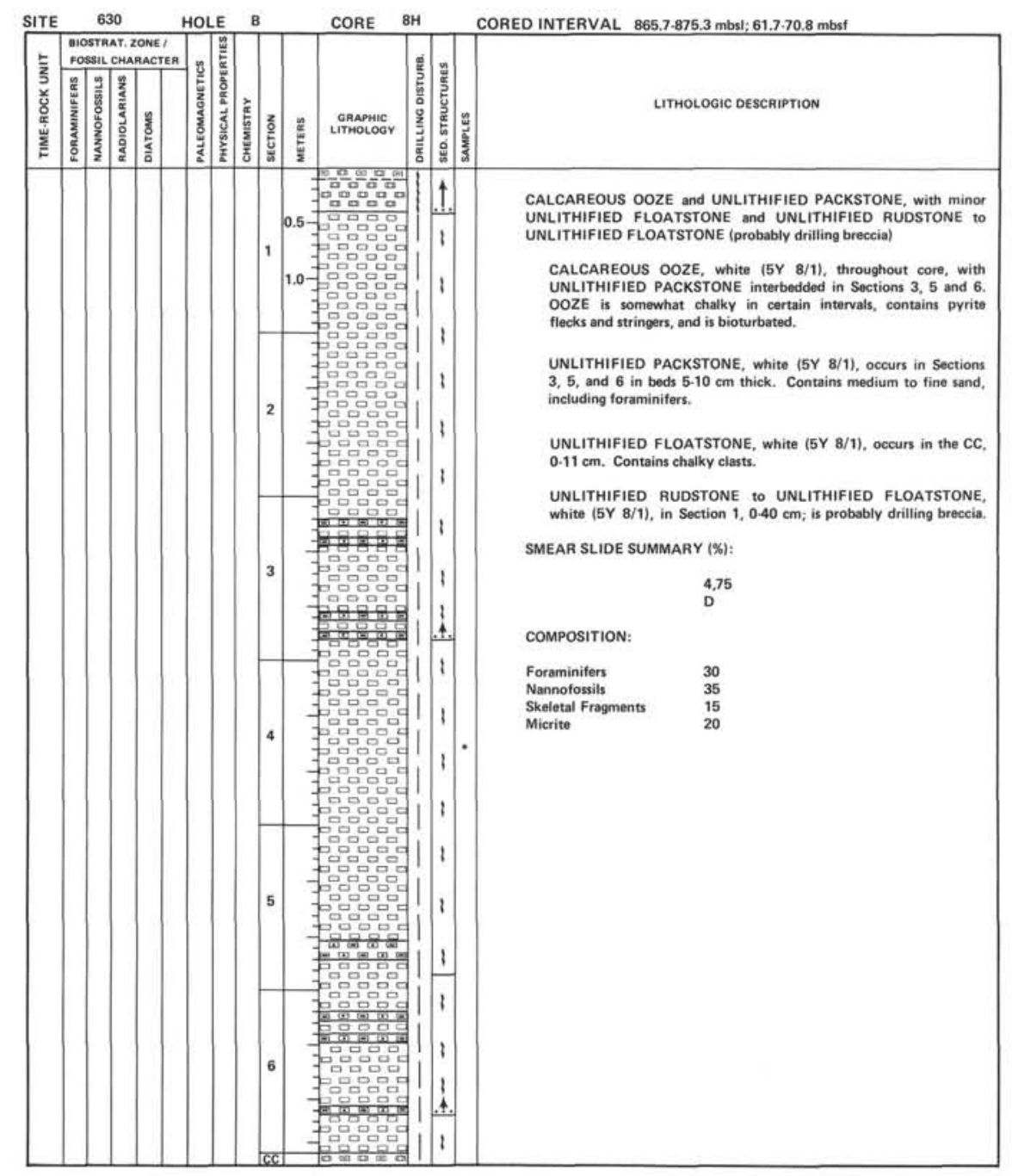




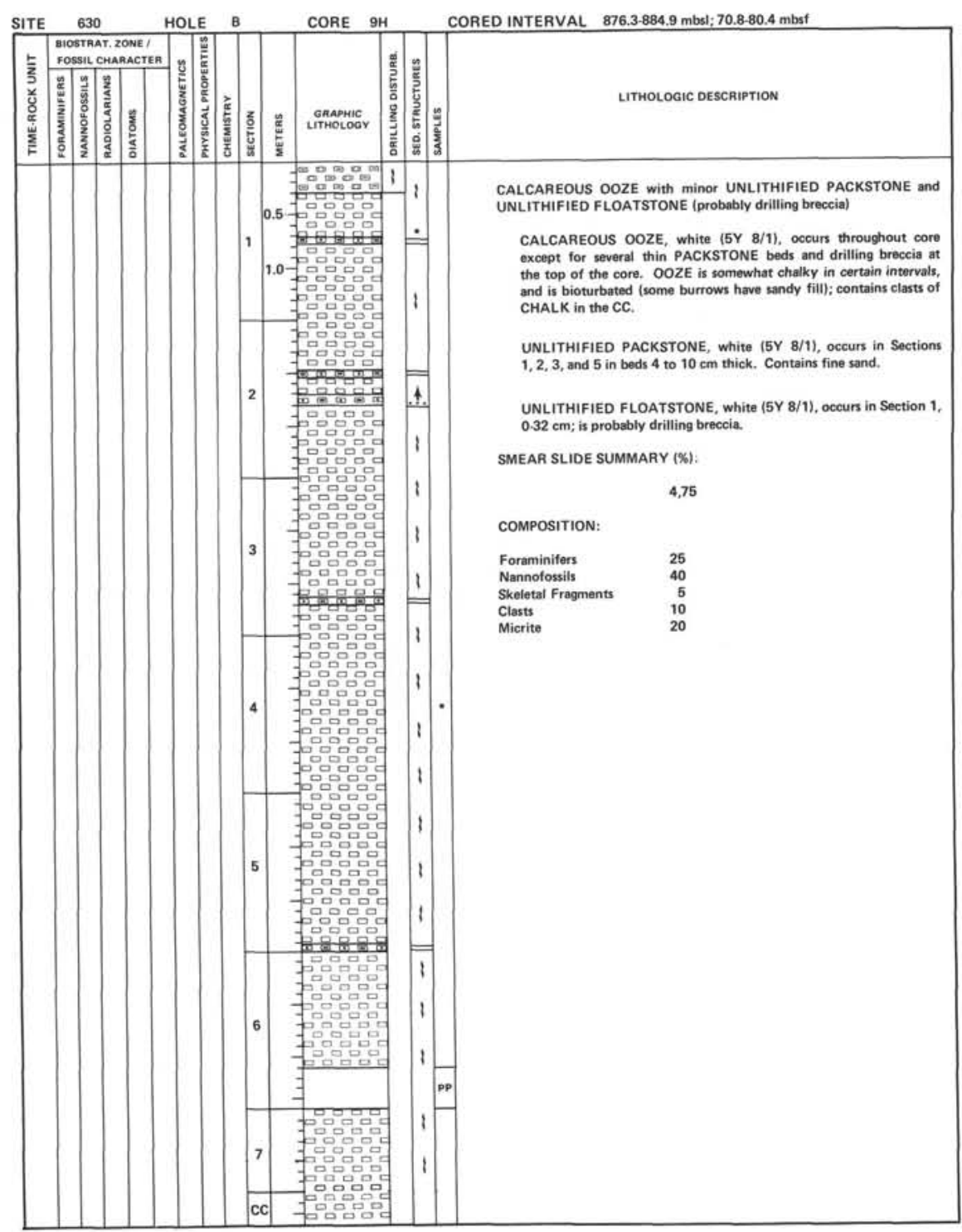

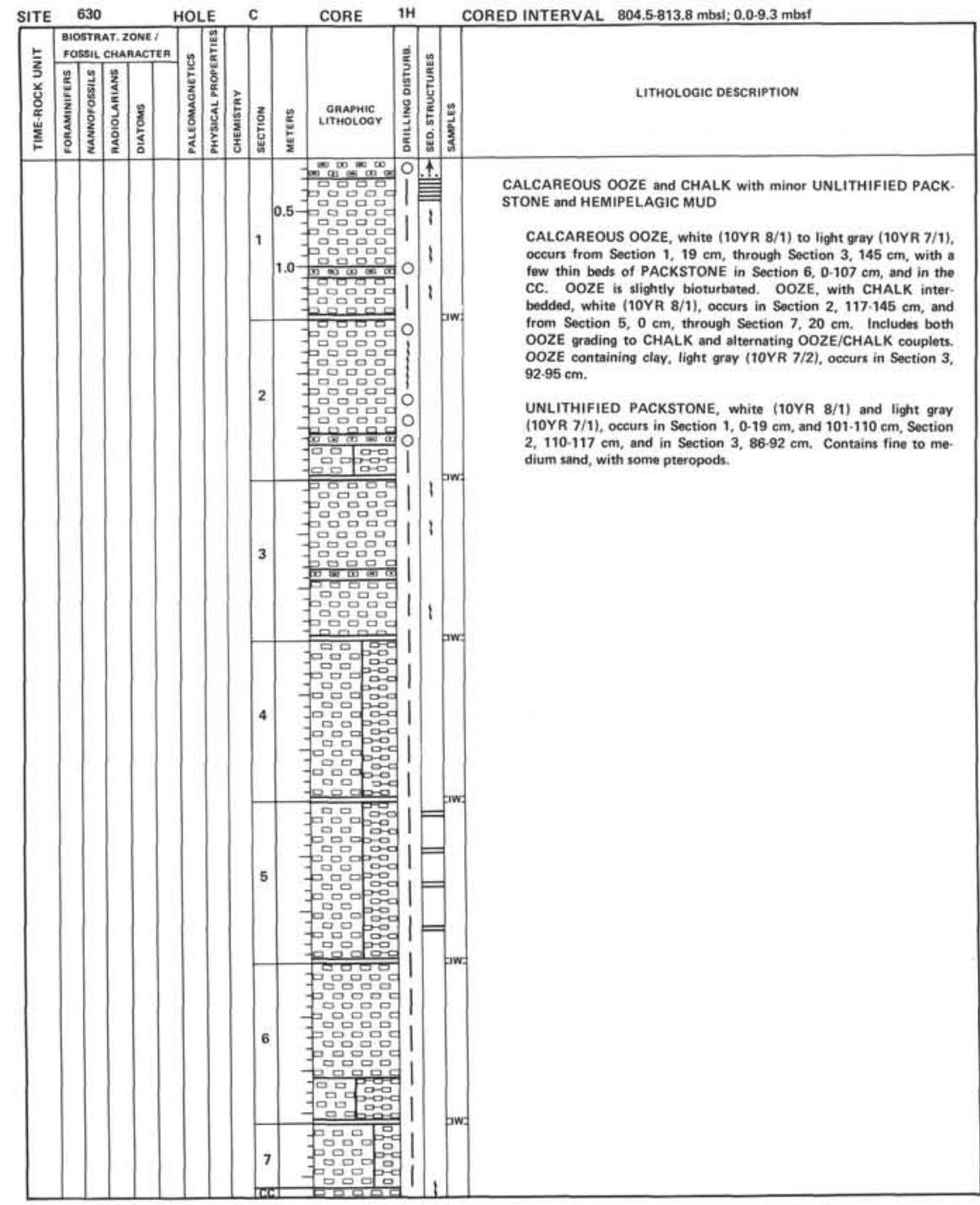


SITE 629 (HOLE A)

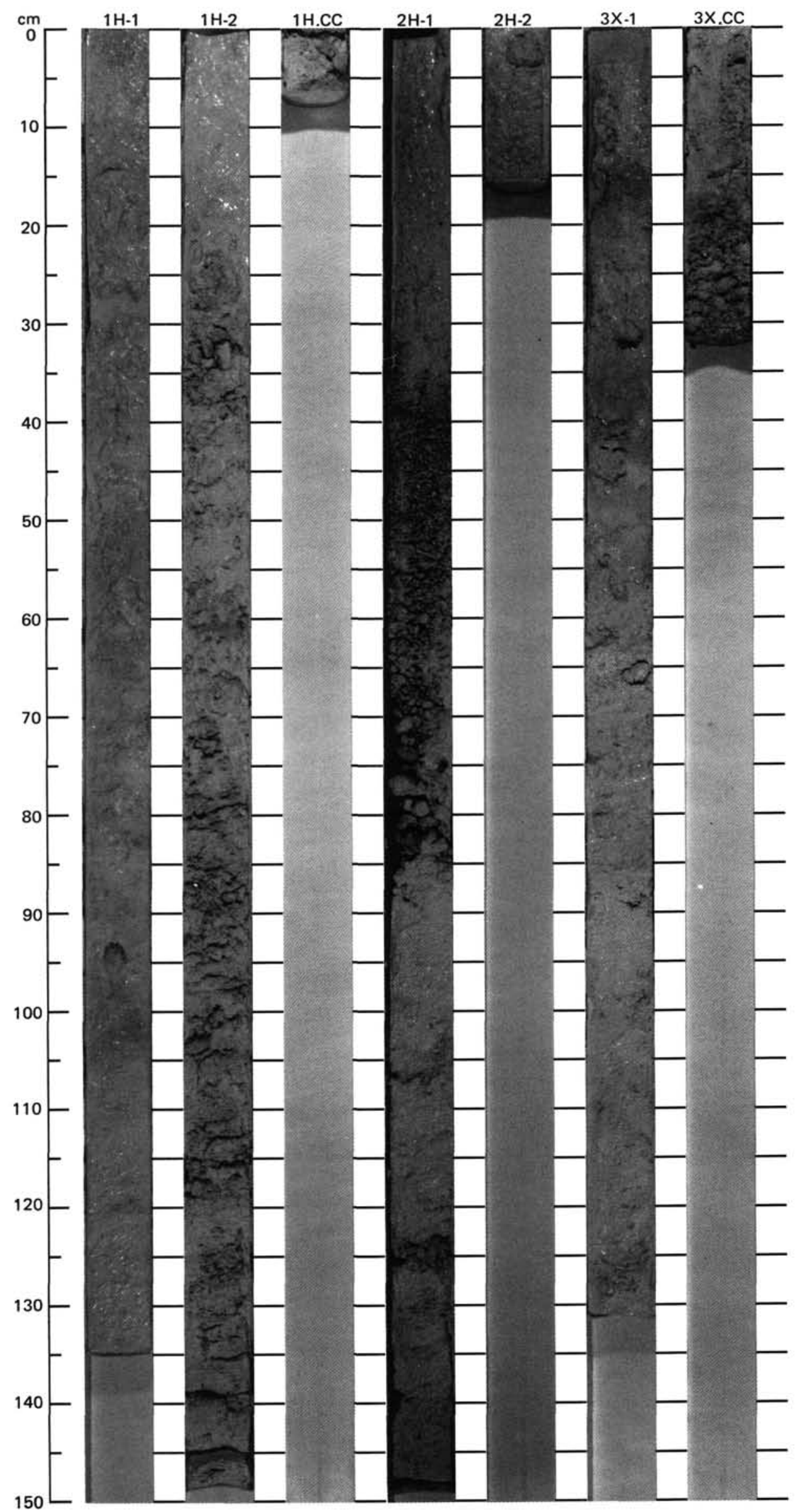


SITE 630 (HOLE A)

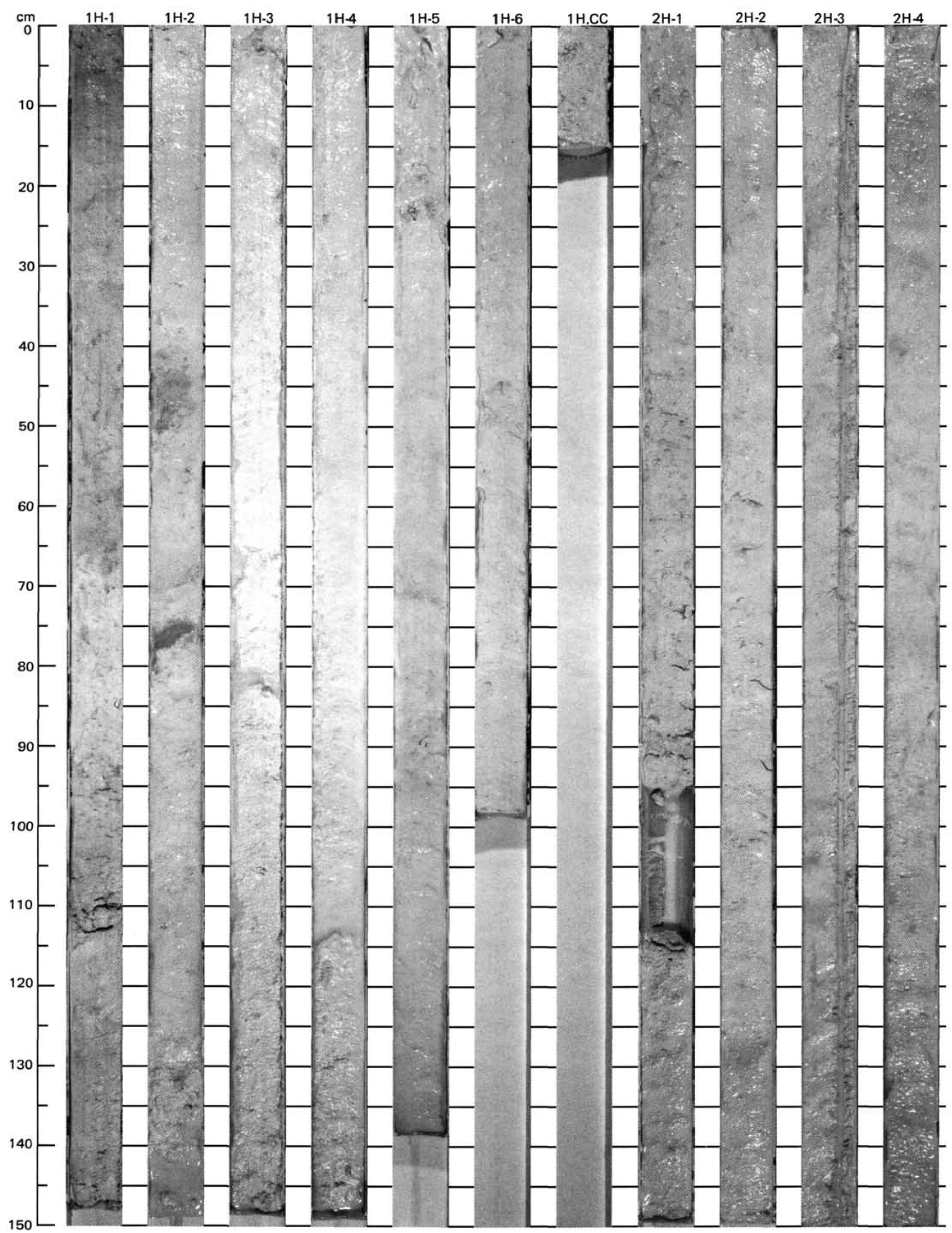


SITE 630 (HOLE A)

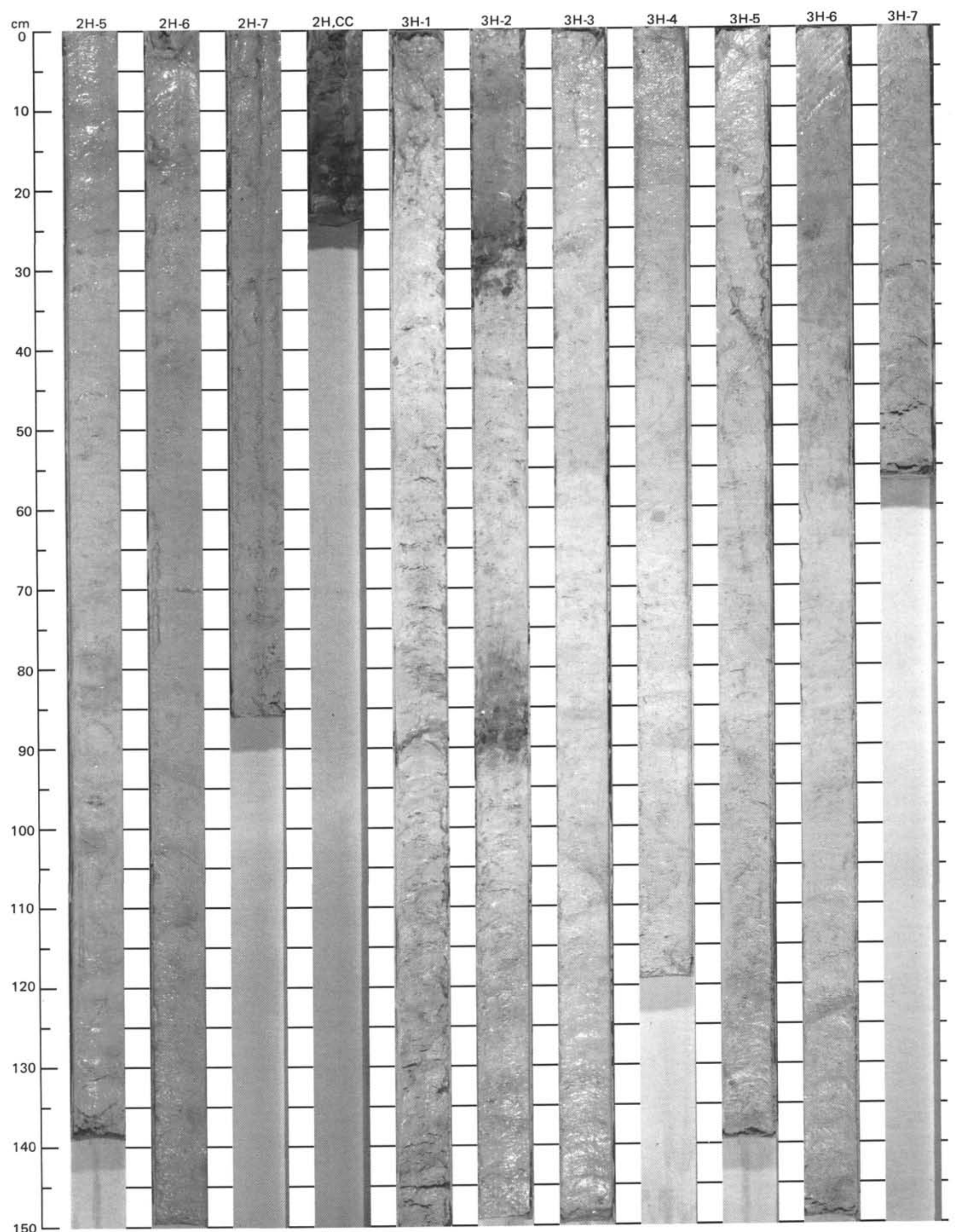


SITE 630 (HOLE A)

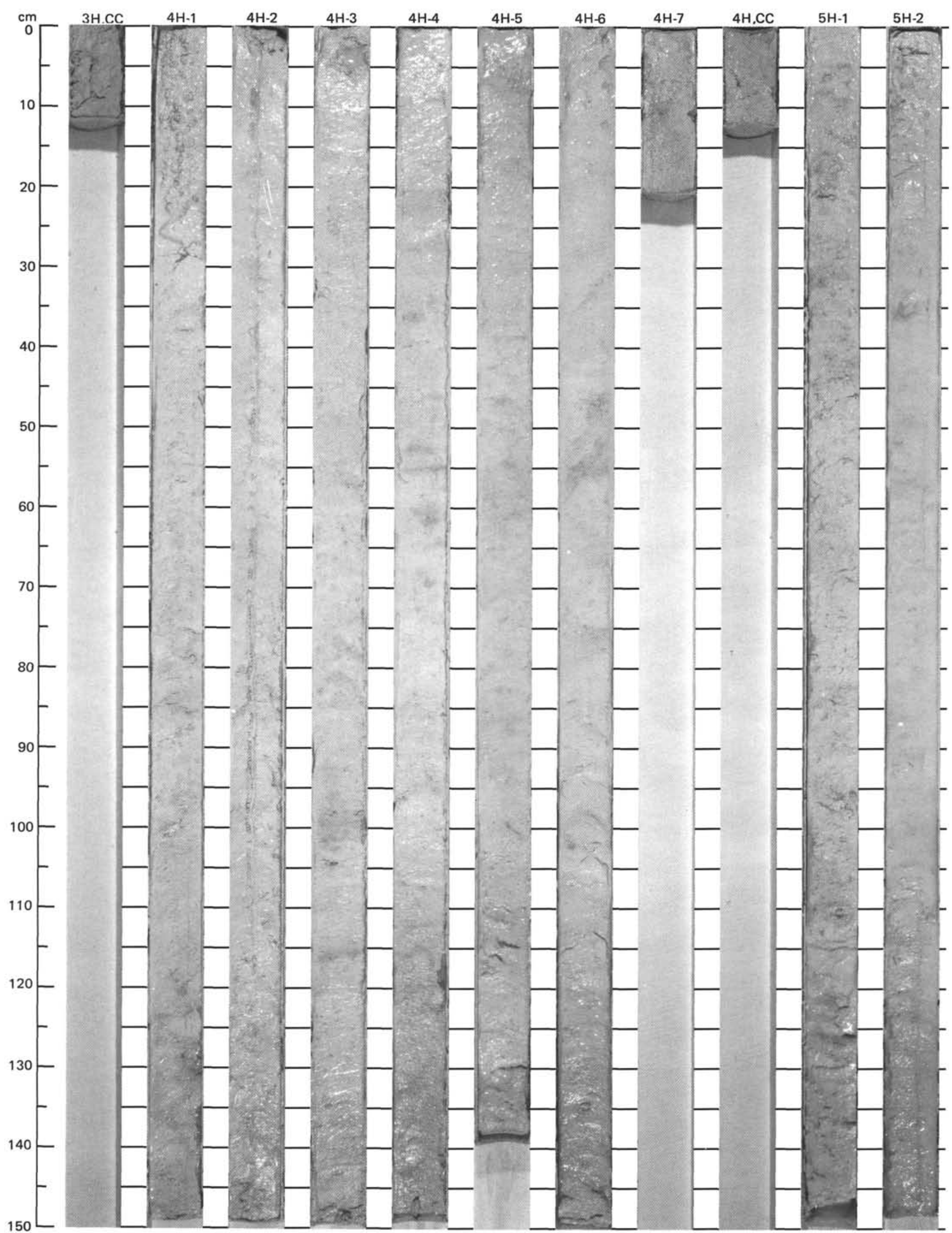


SITE 630 (HOLE A)

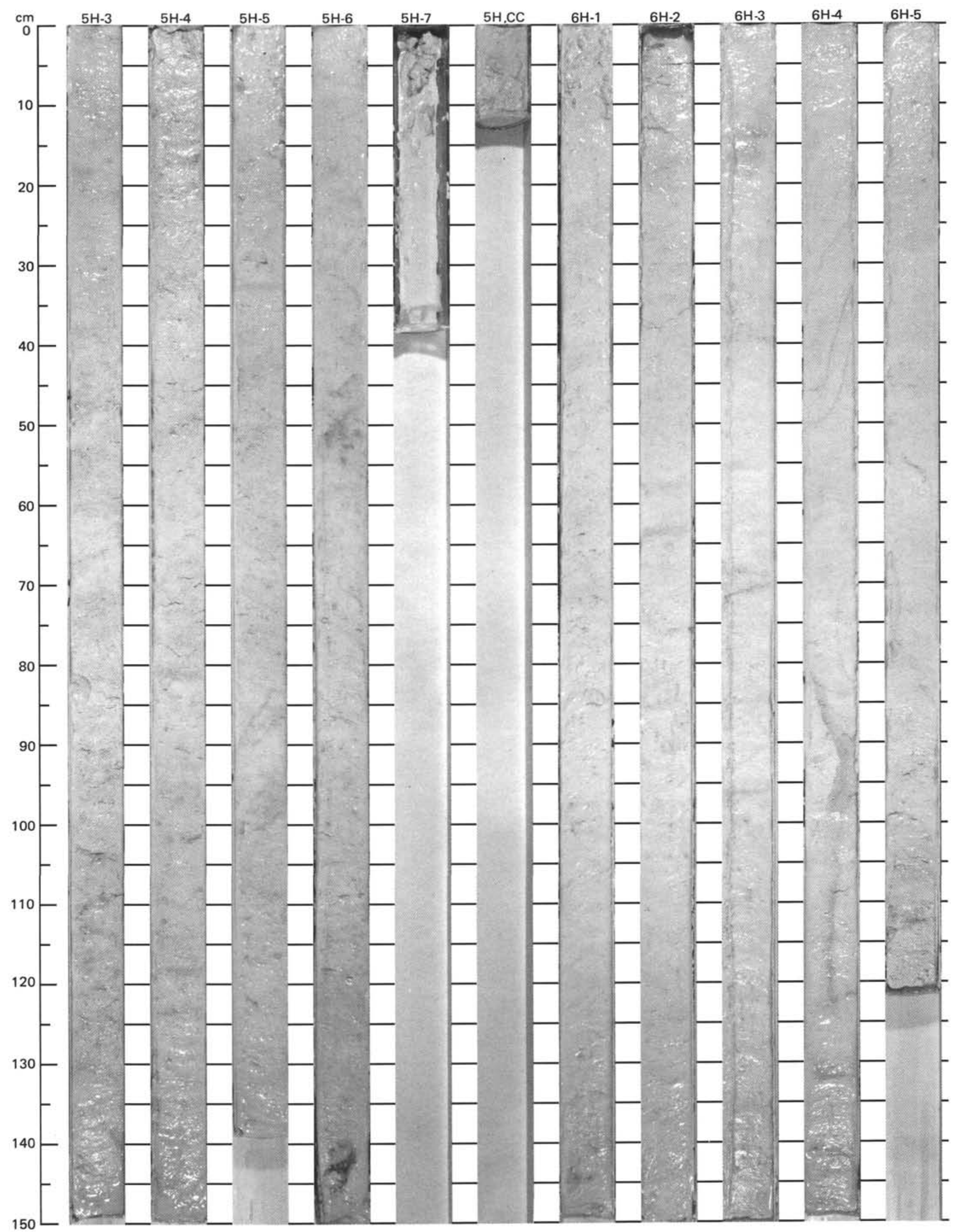


SITE 630 (HOLE A)

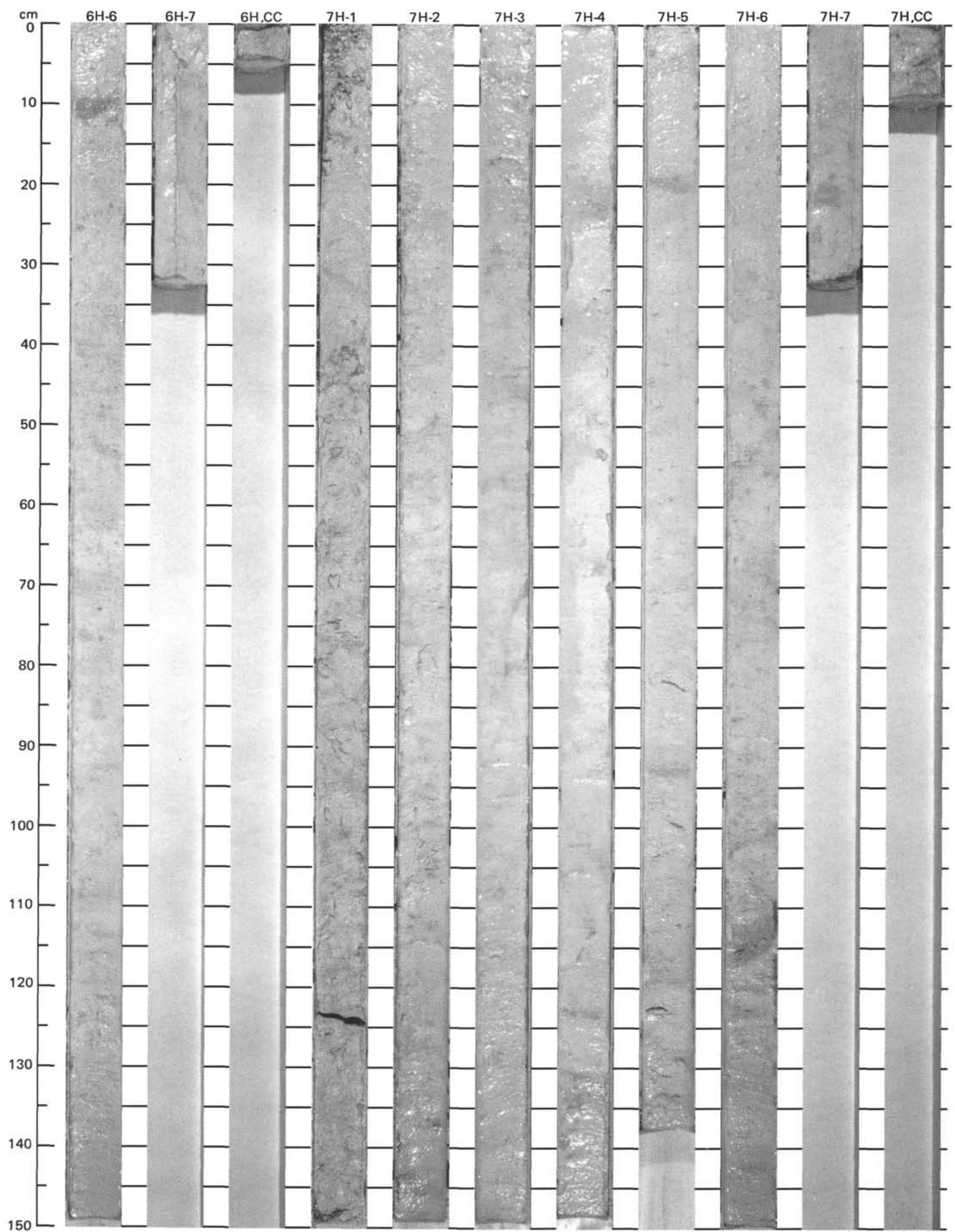


SITE 630 (HOLE A)

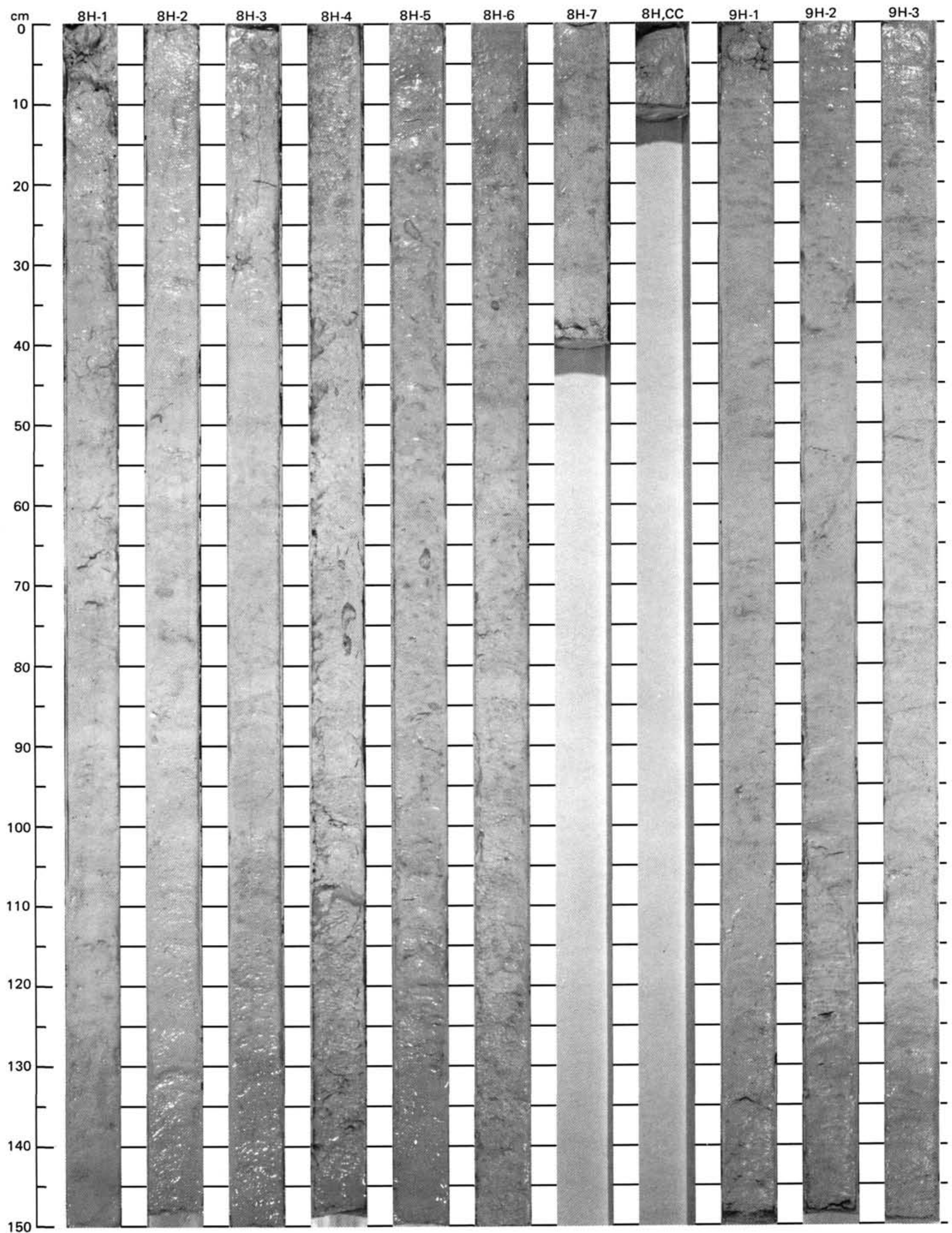


SITE 630 (HOLE A)

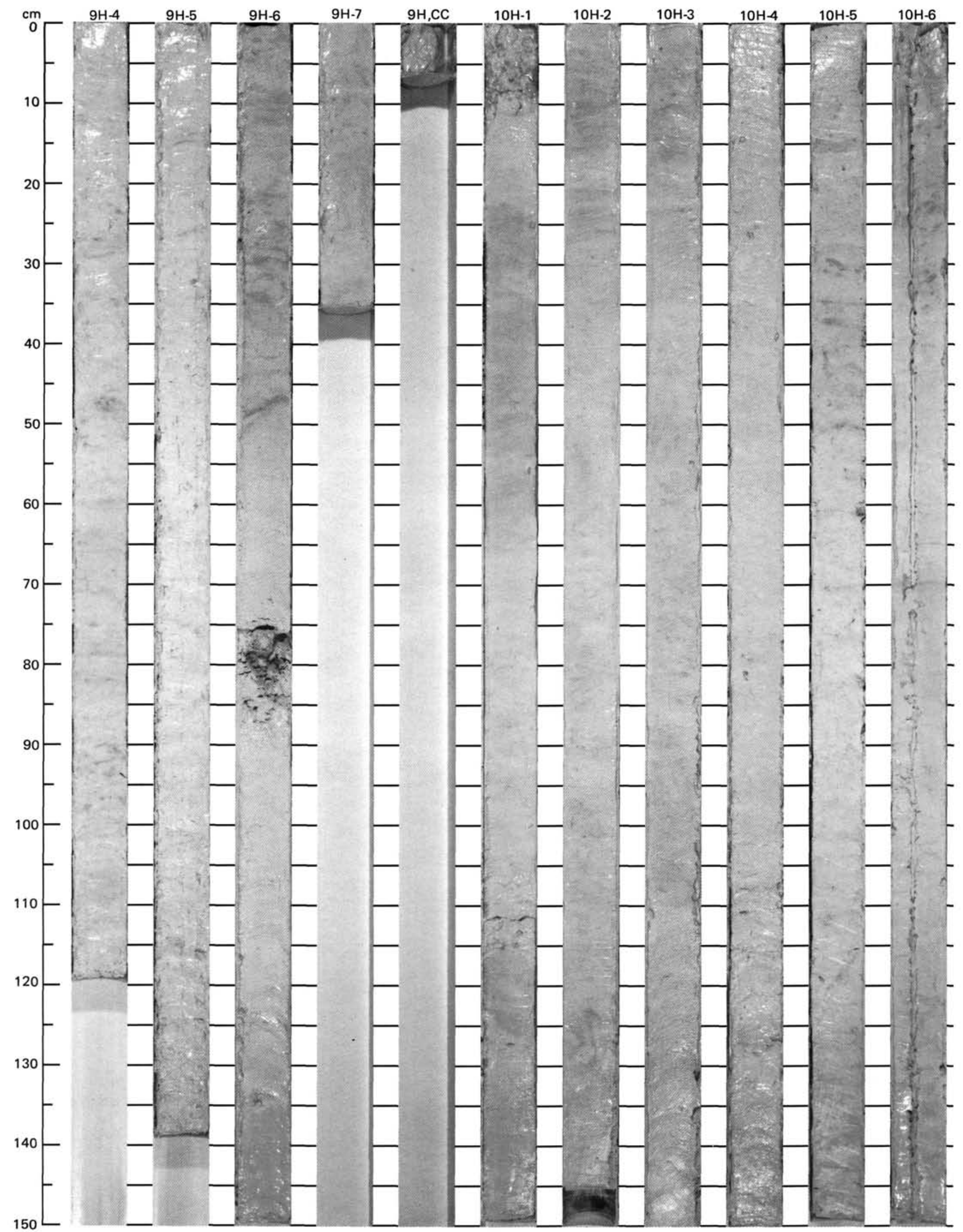


SITE 630 (HOLE A)

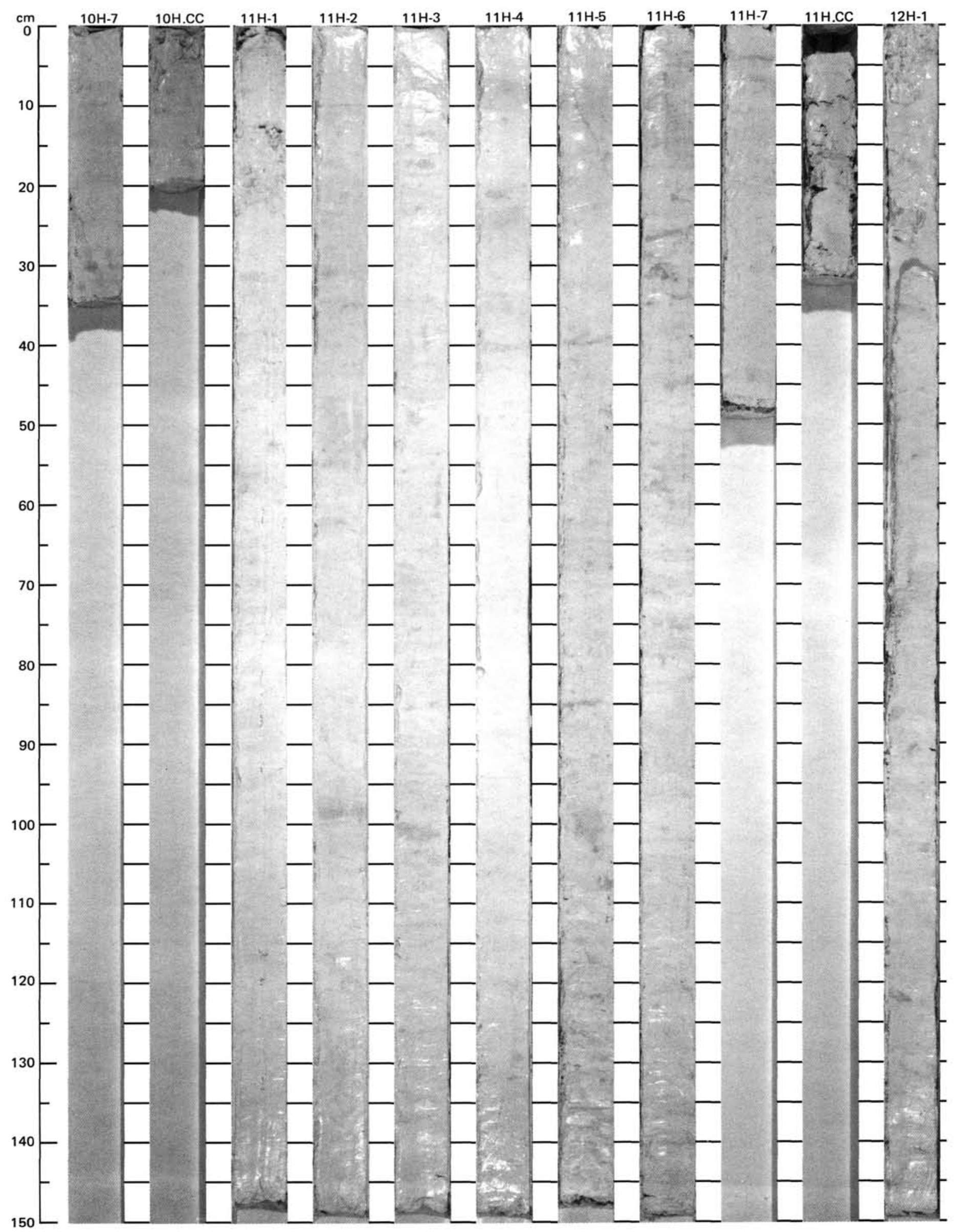




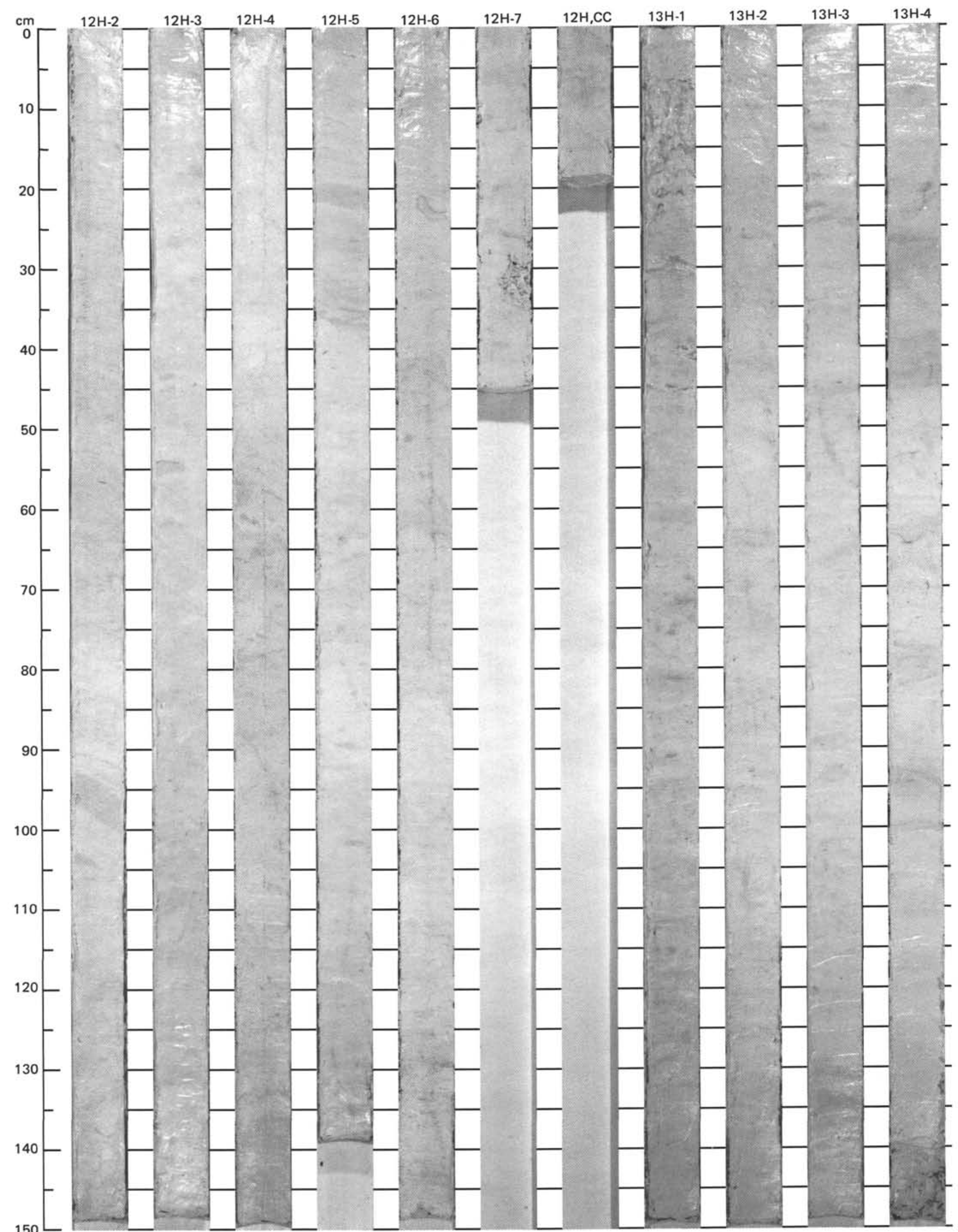




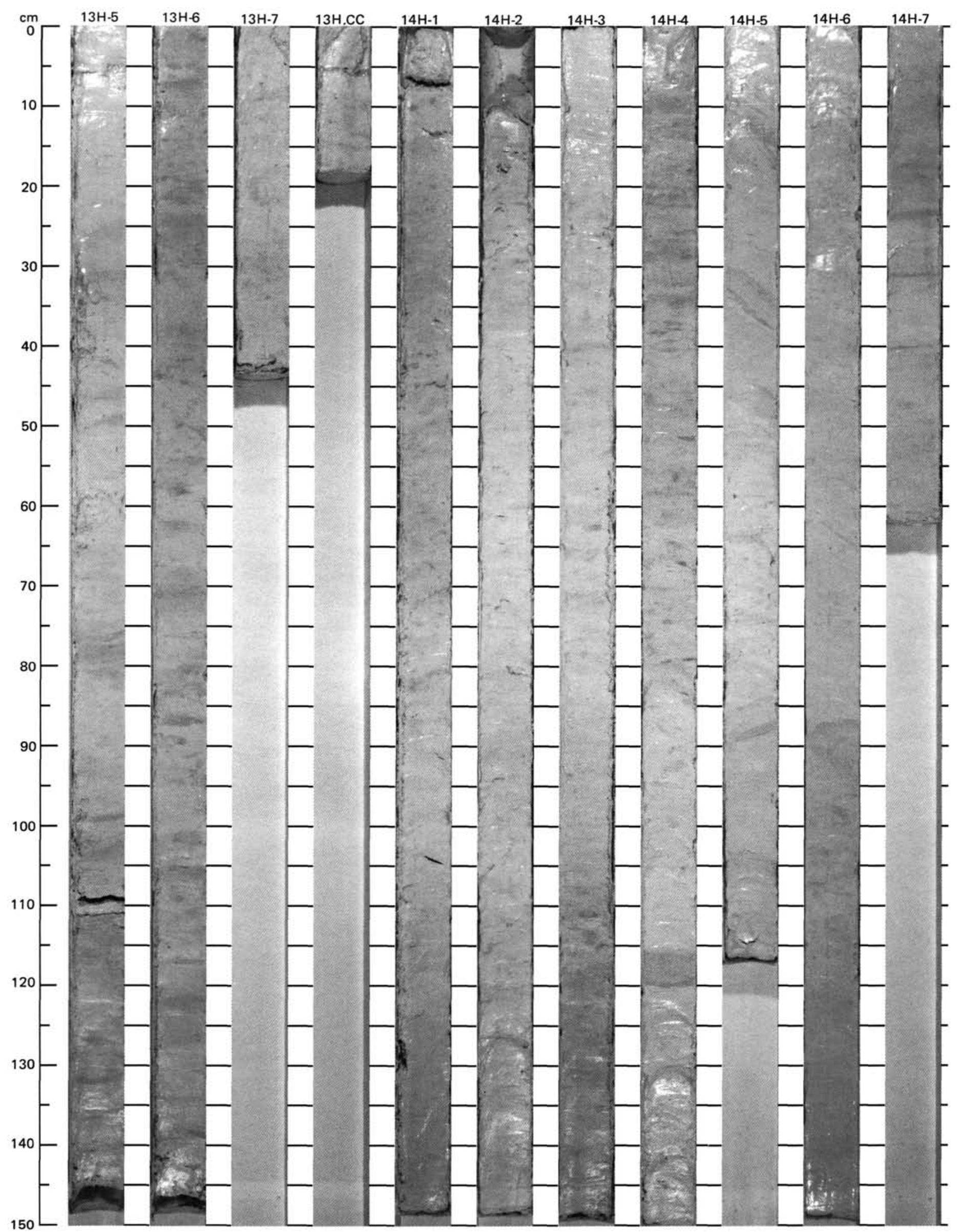




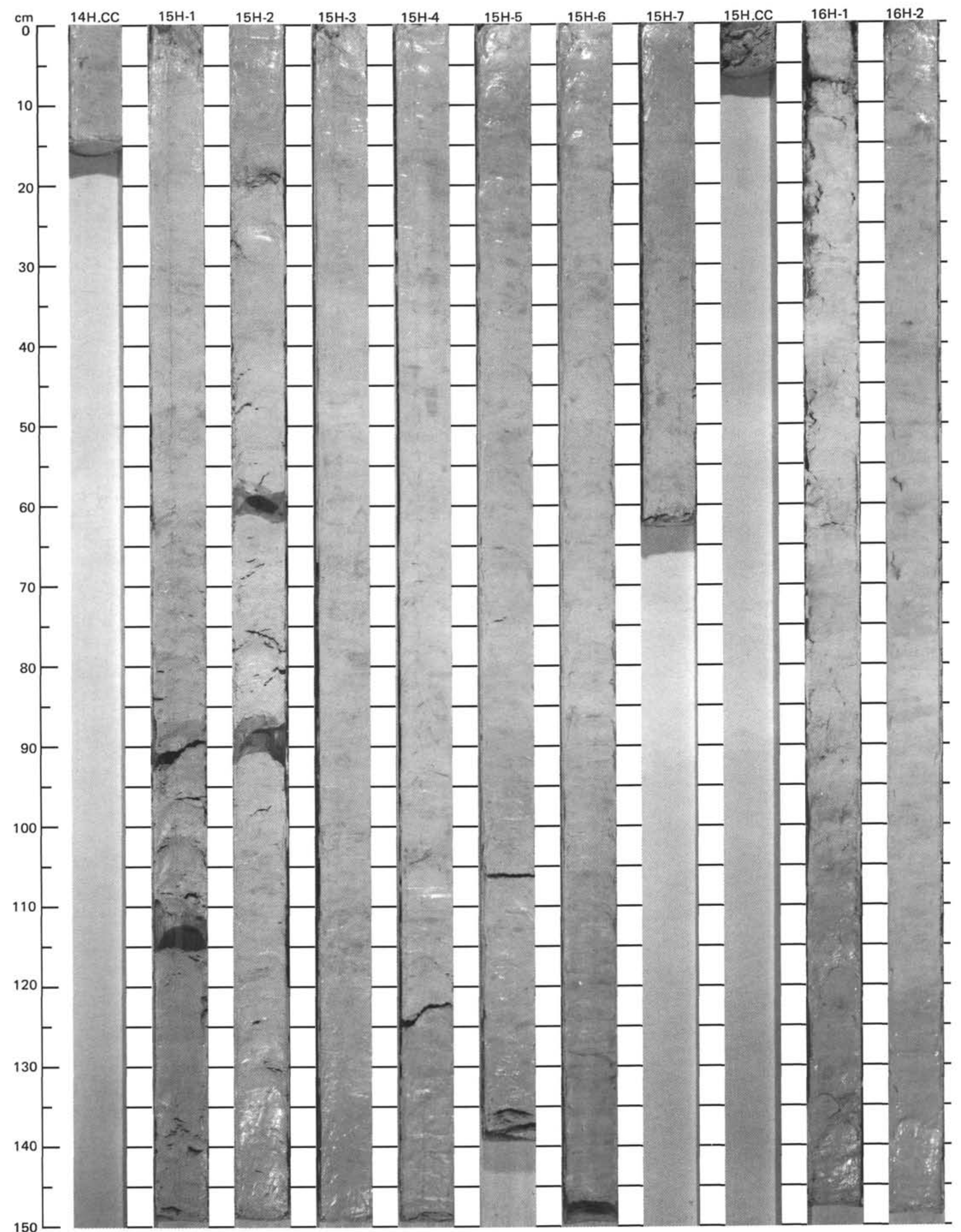


SITE 630 (HOLE A)

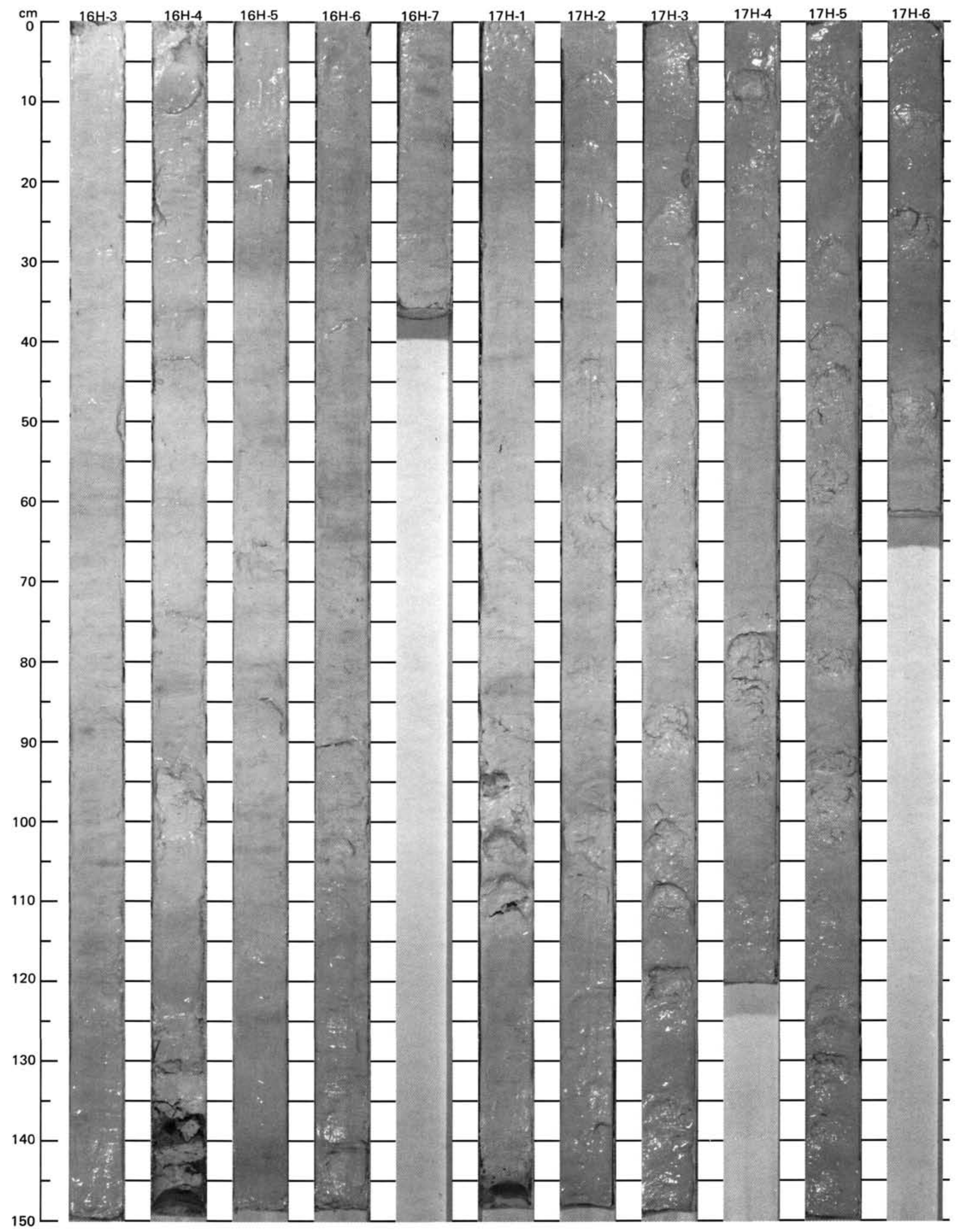


SITE 630 (HOLE A)

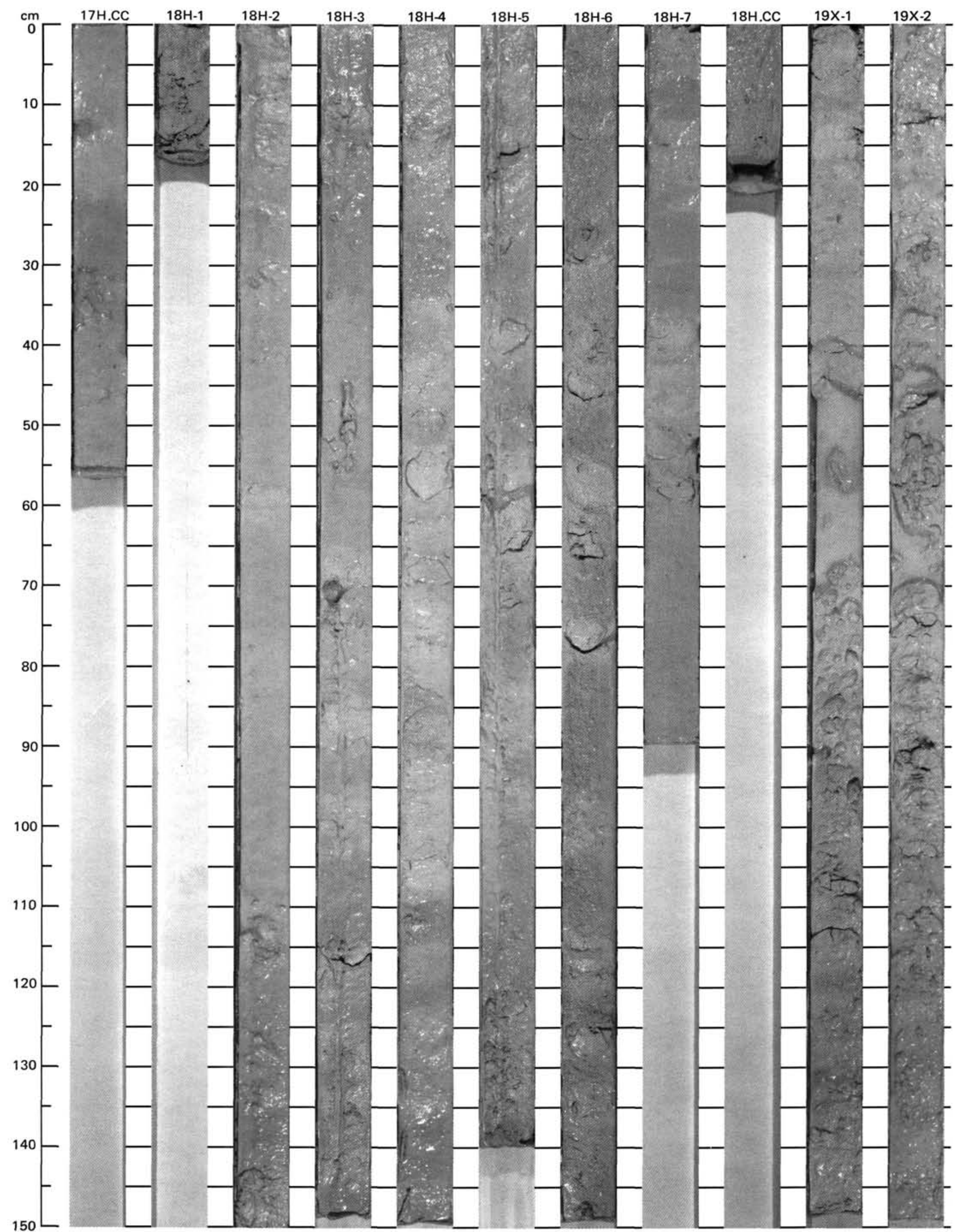




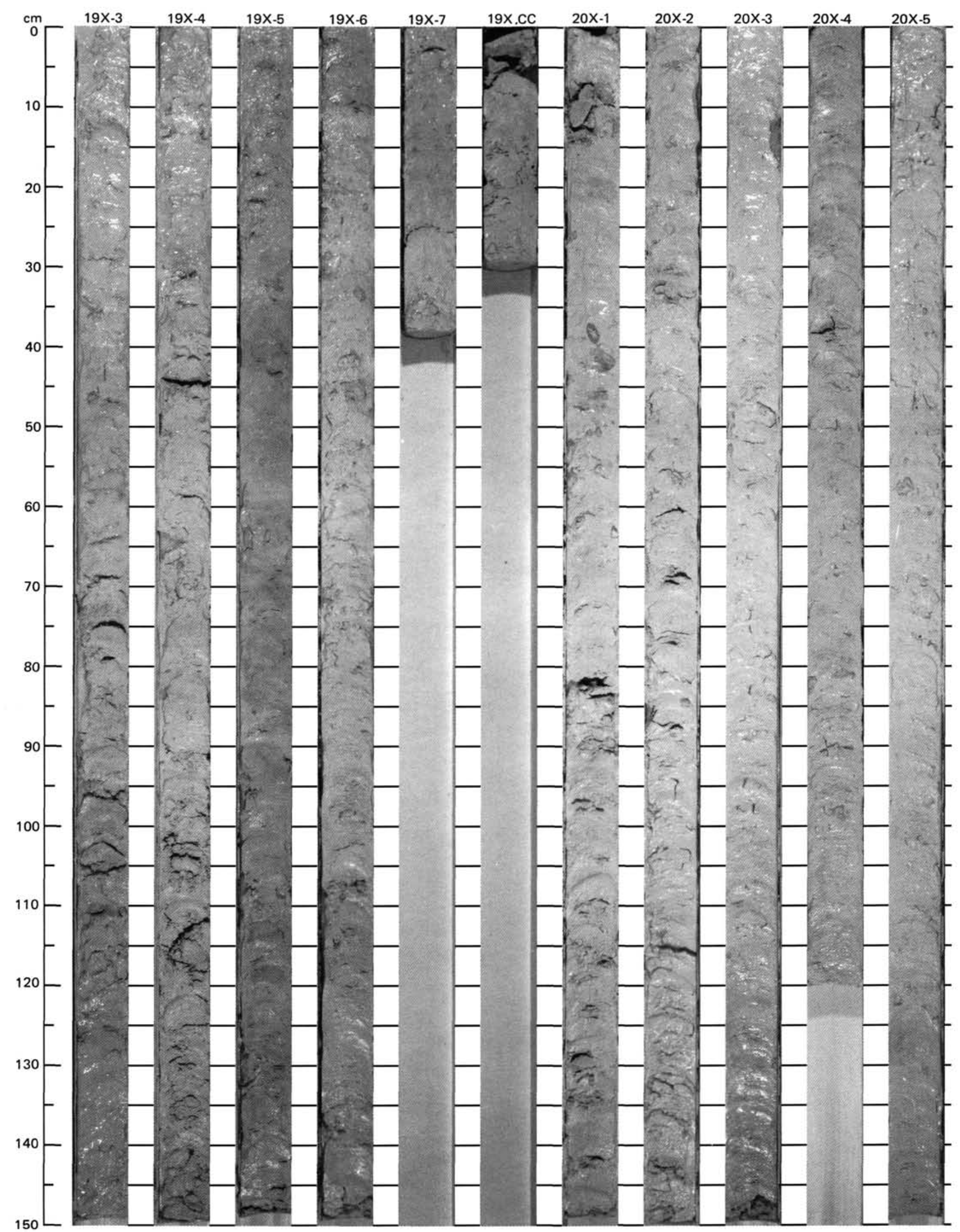


SITE 630 (HOLE A)

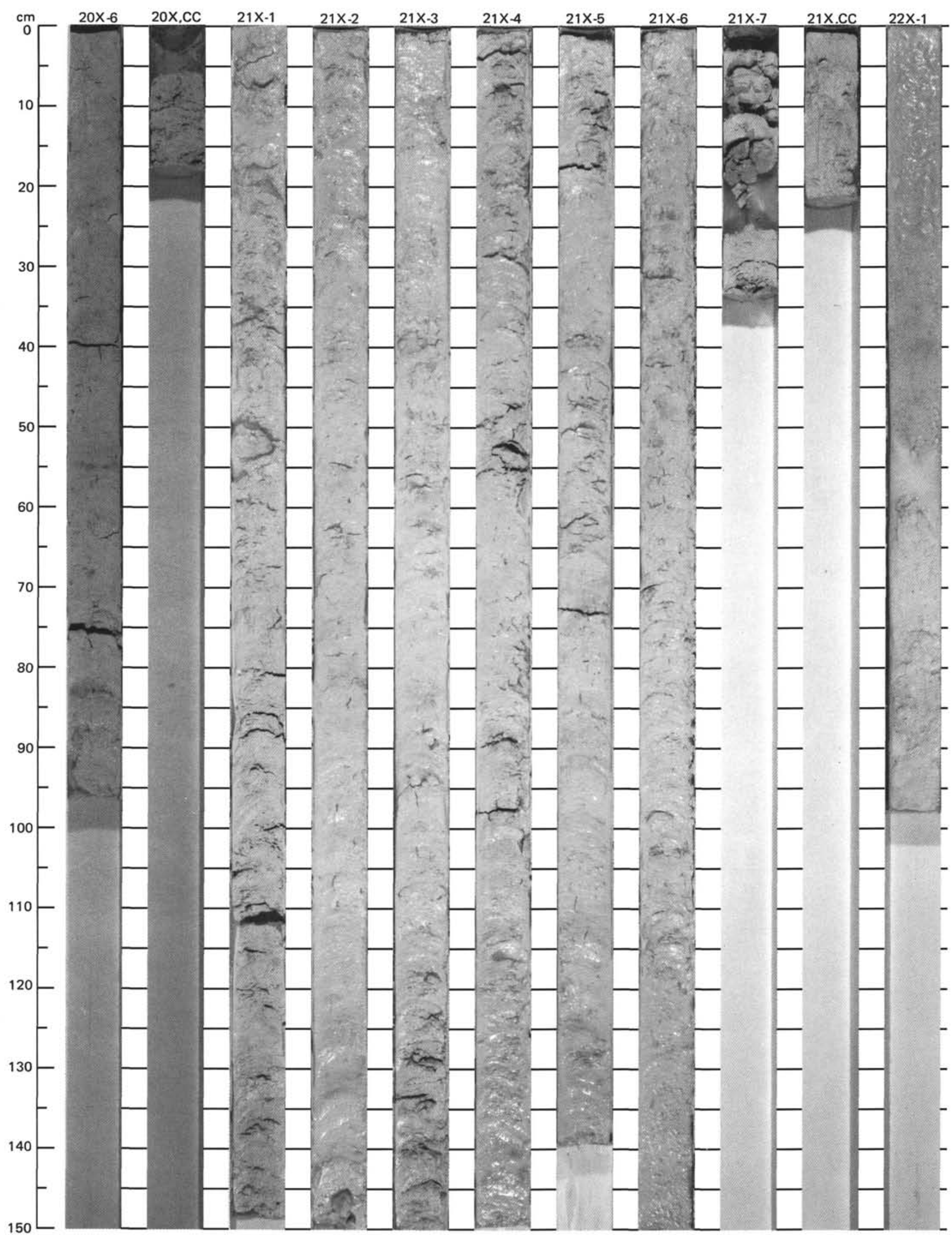


SITE 630 (HOLE A)

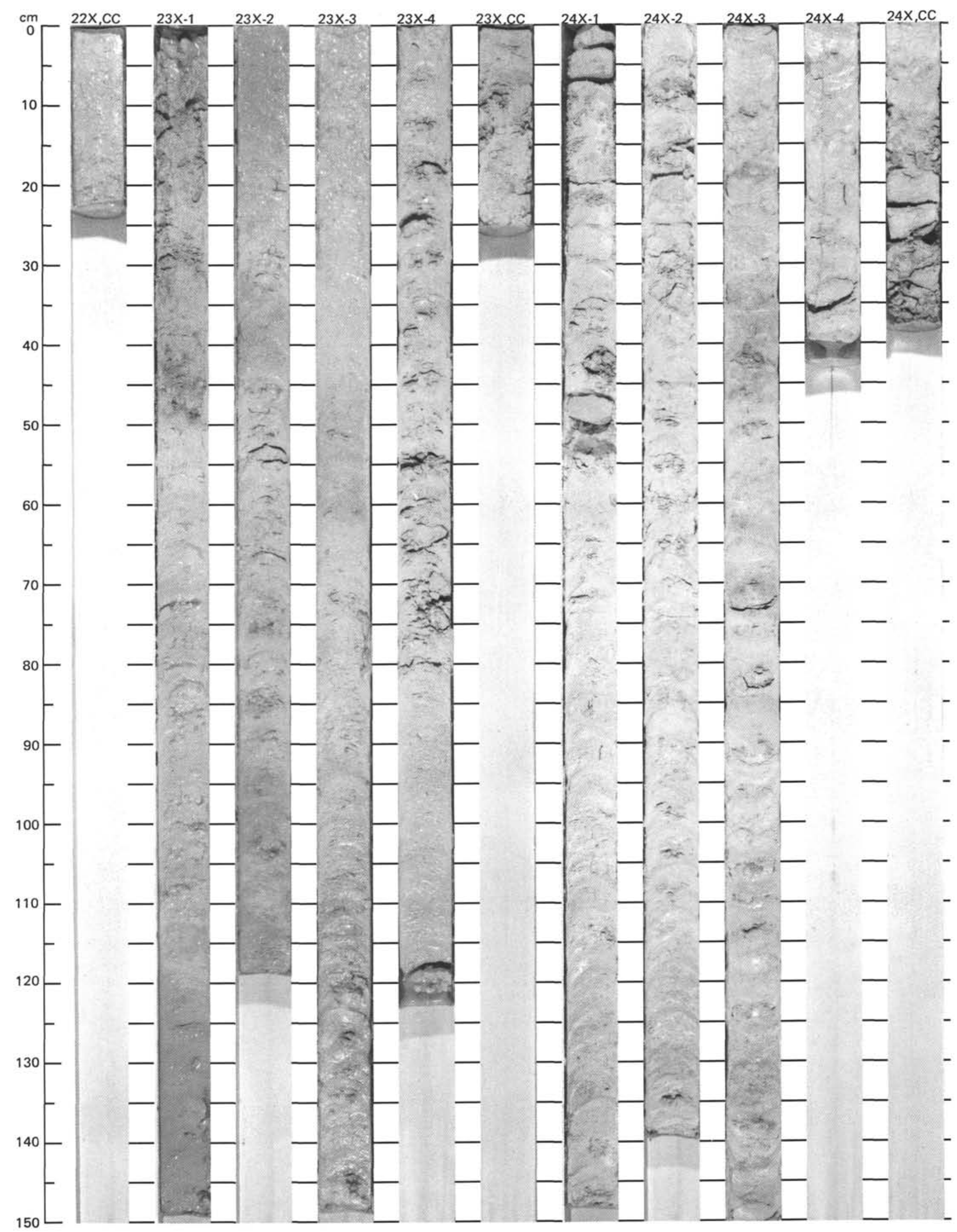


SITE 630 (HOLE A)

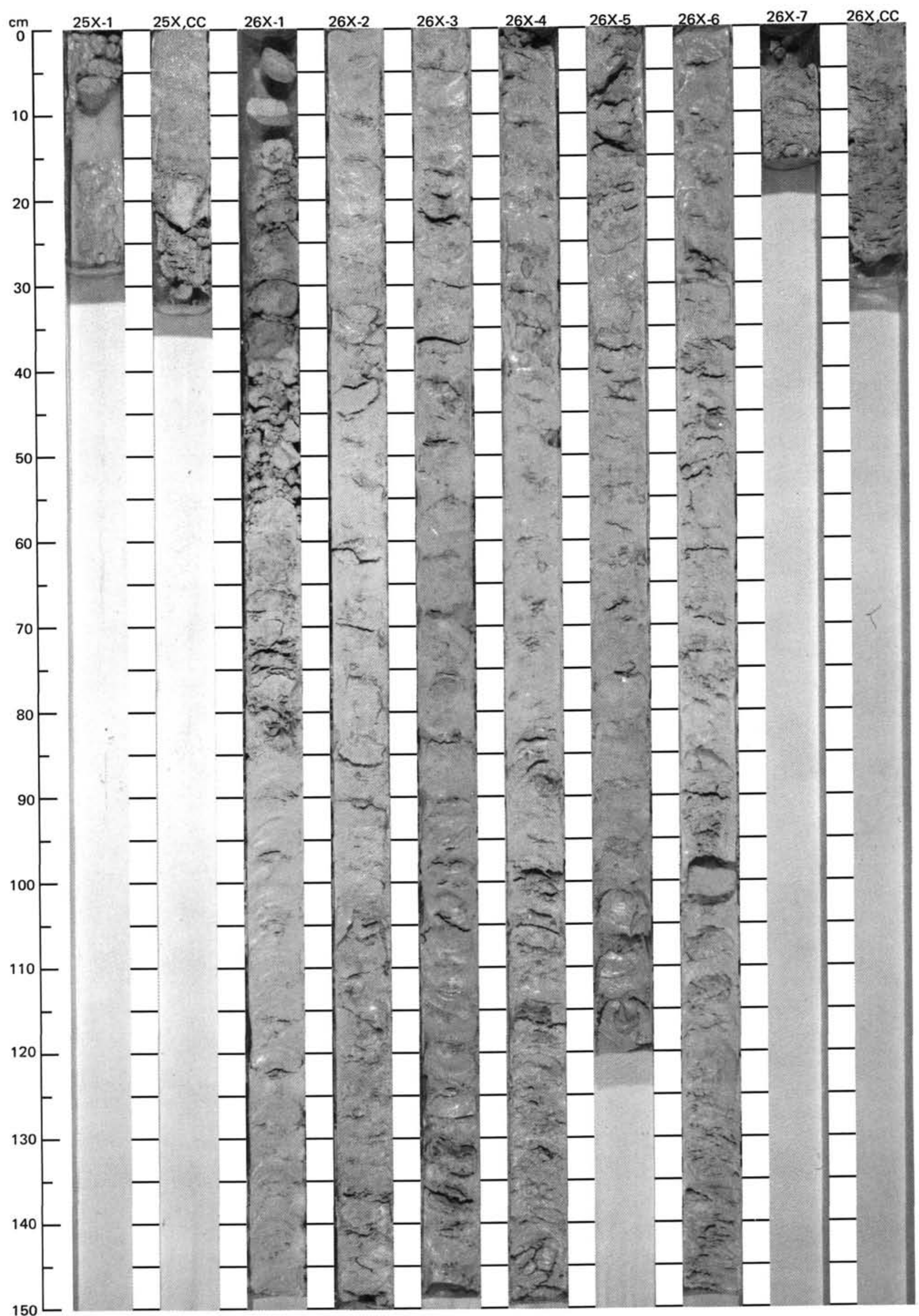


SITE 630 (HOLE B)

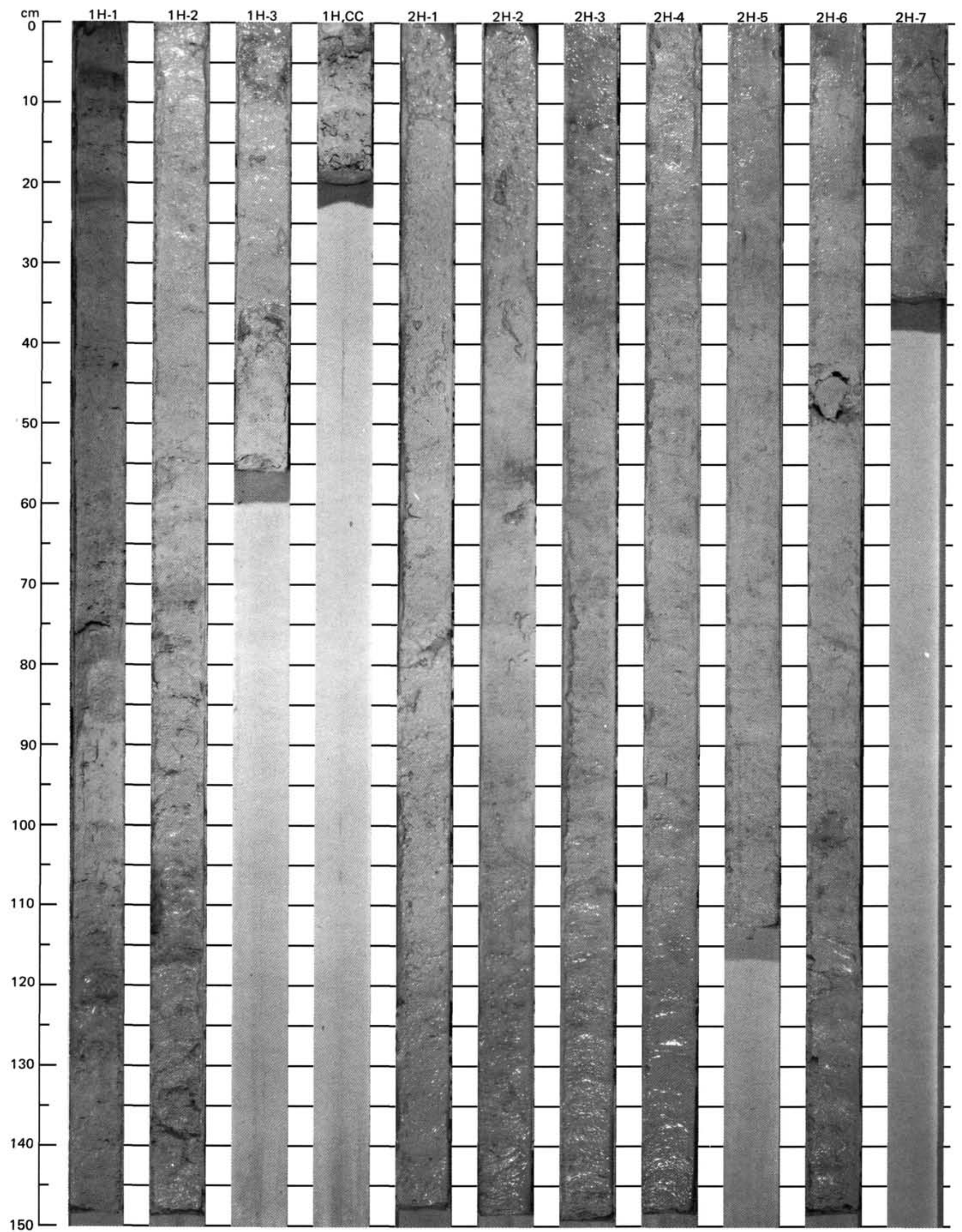


SITE 630 (HOLE B)

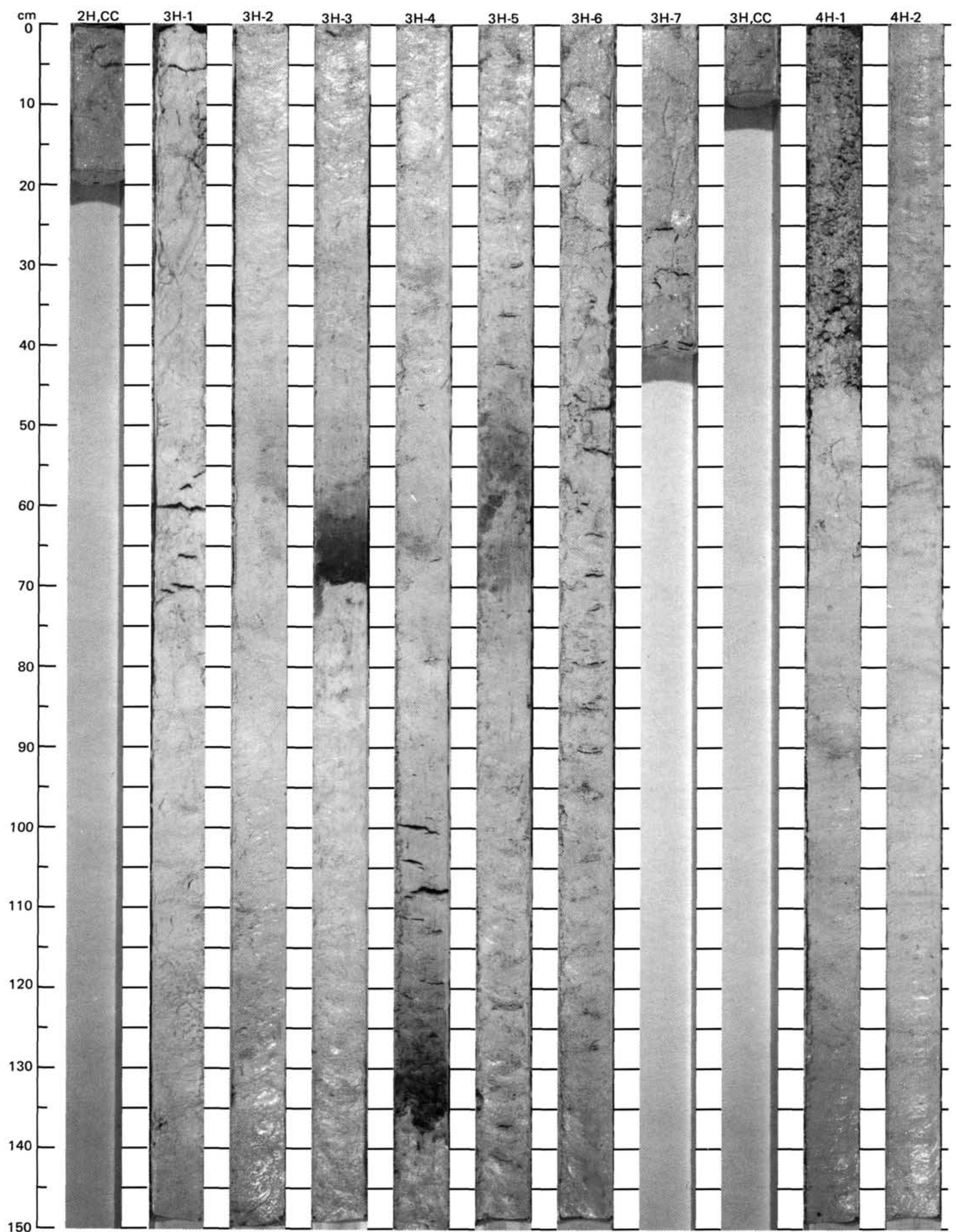




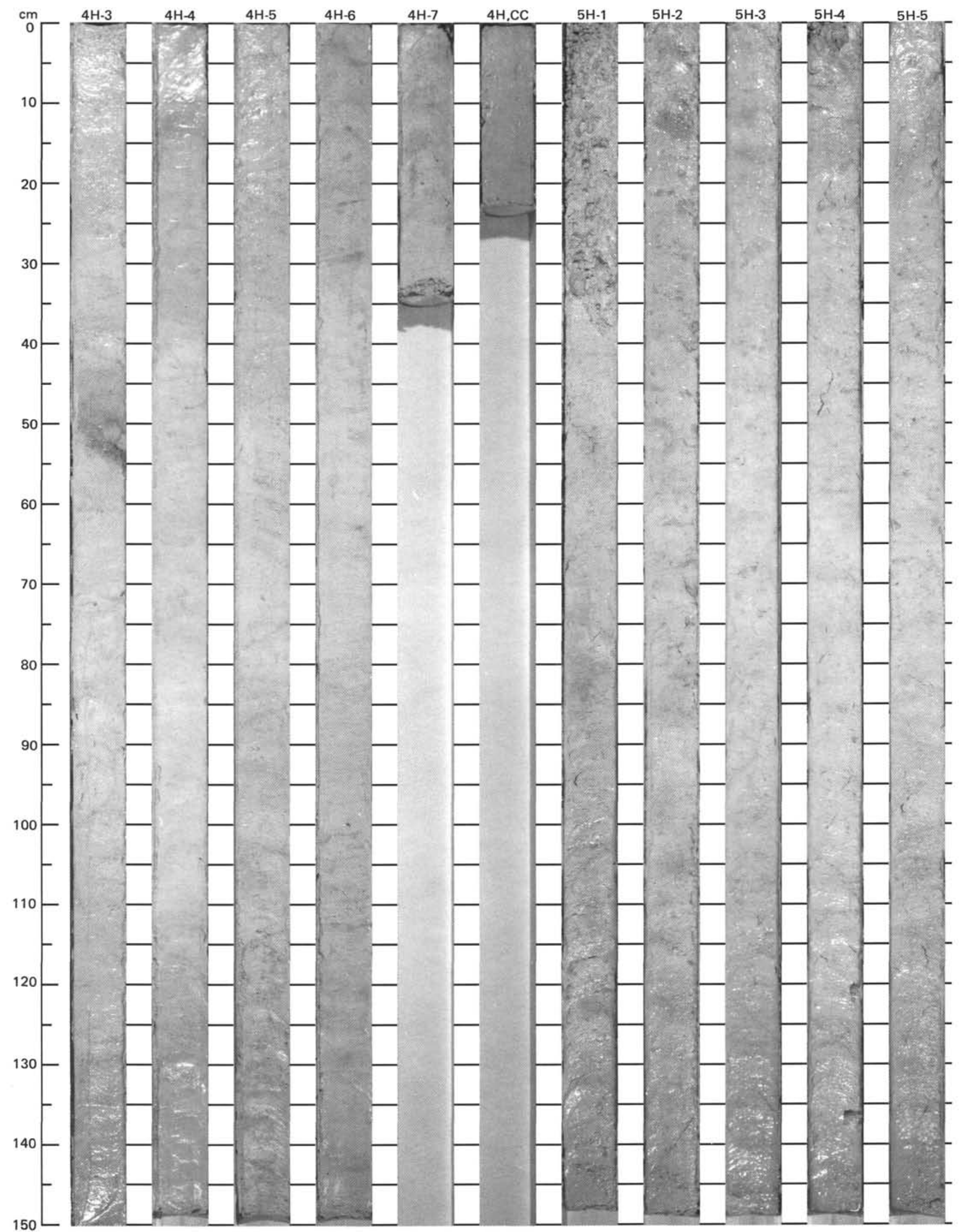




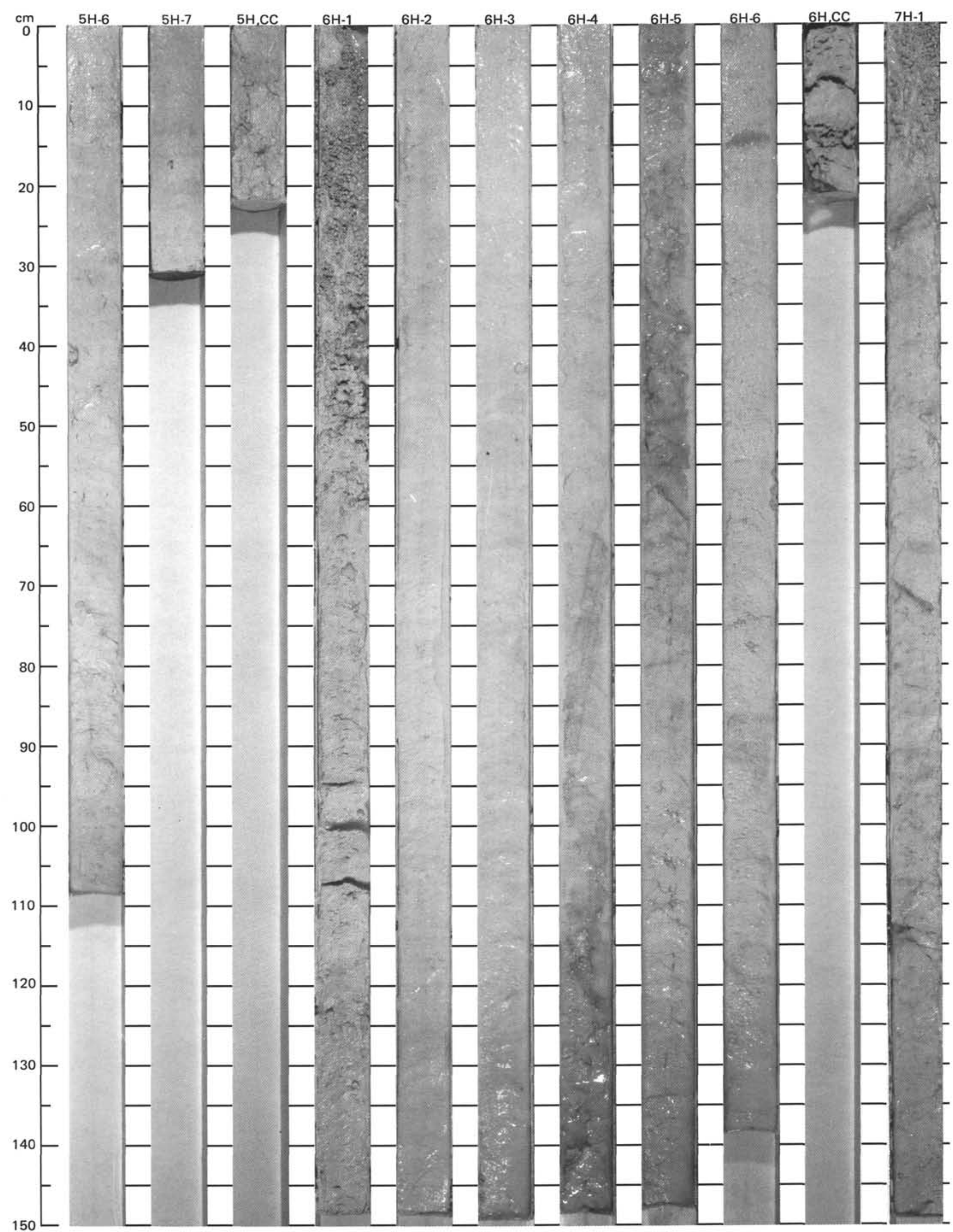


SITE 630 (HOLE B)

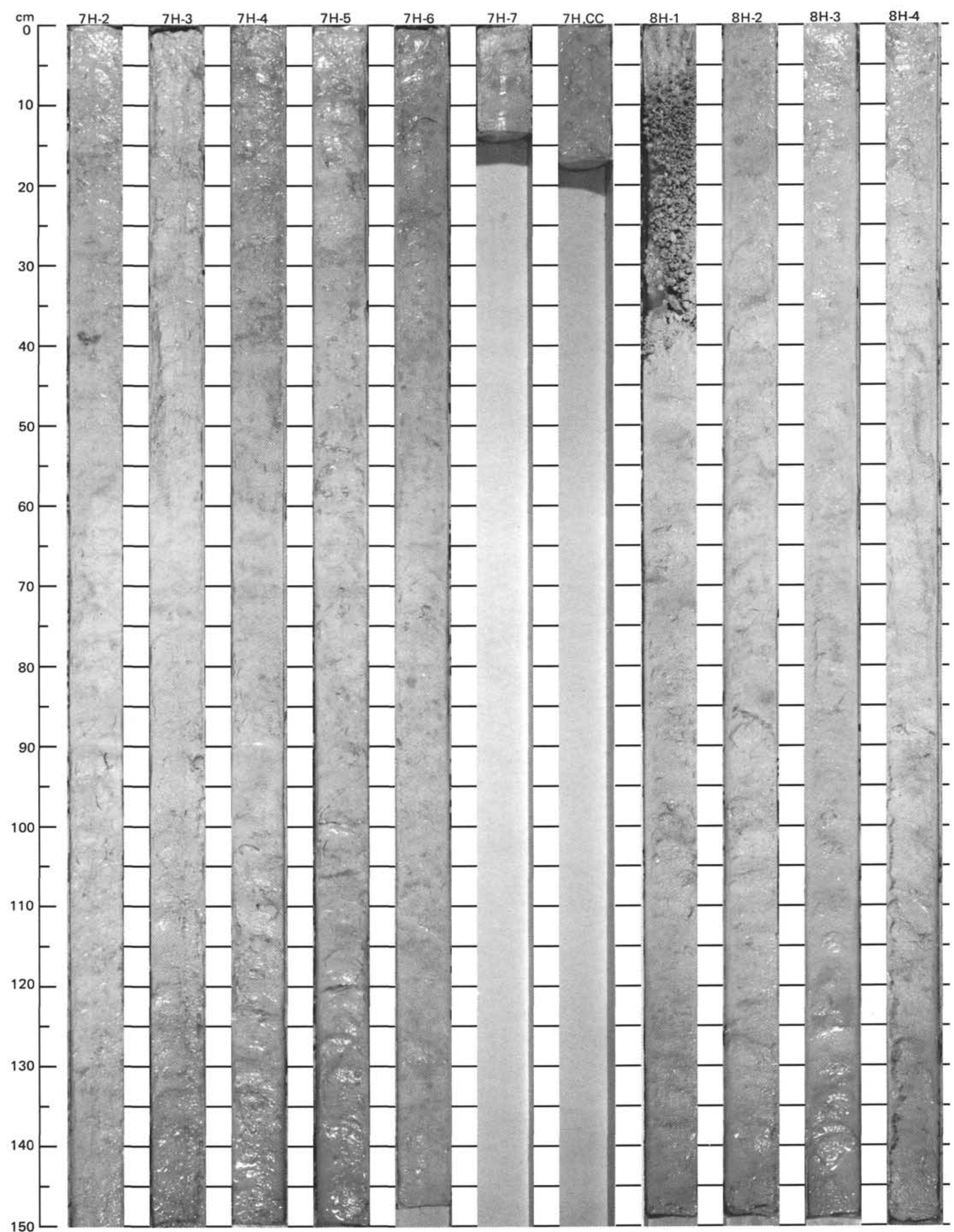


SITE 630 (HOLE B)

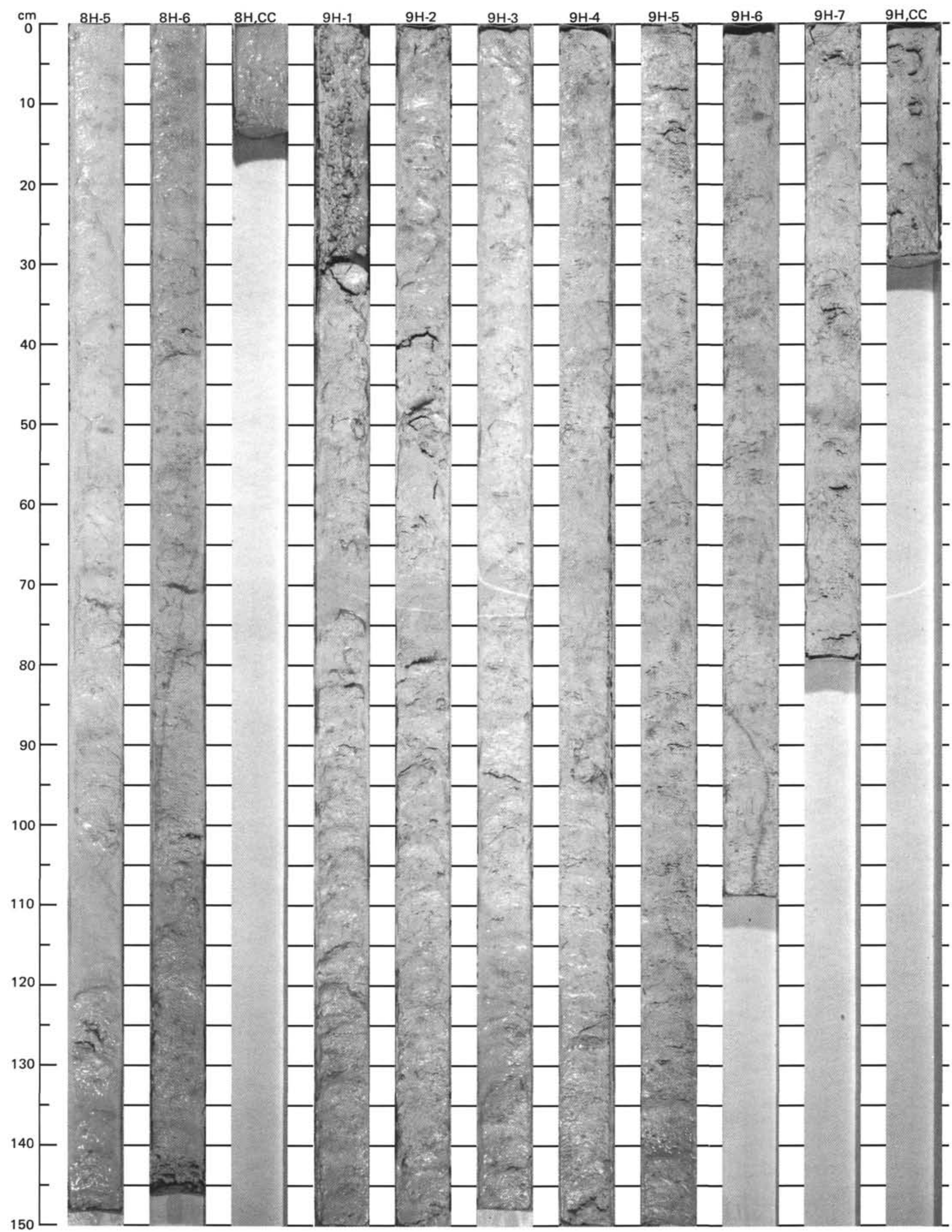


SITE 630 (HOLE C)

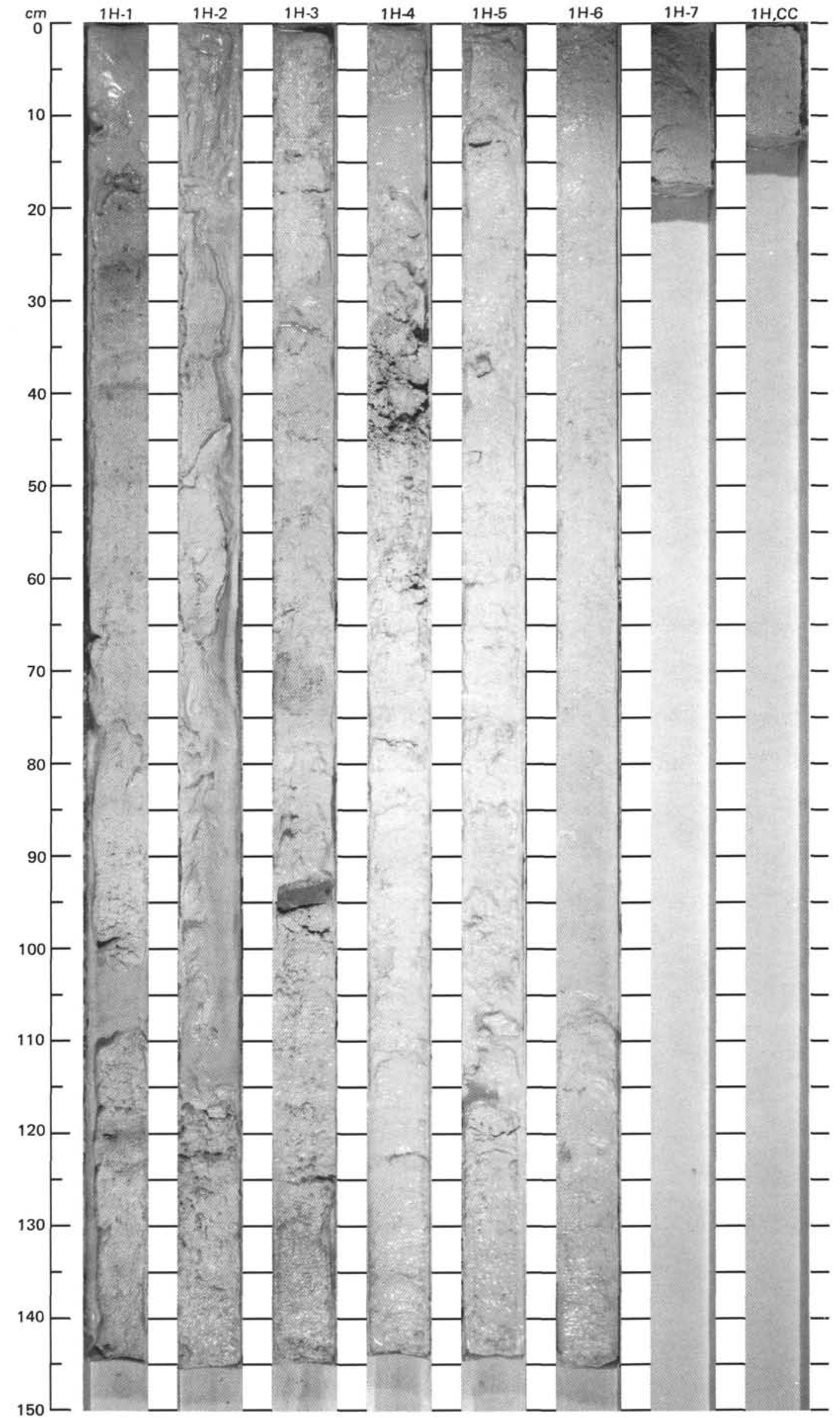

